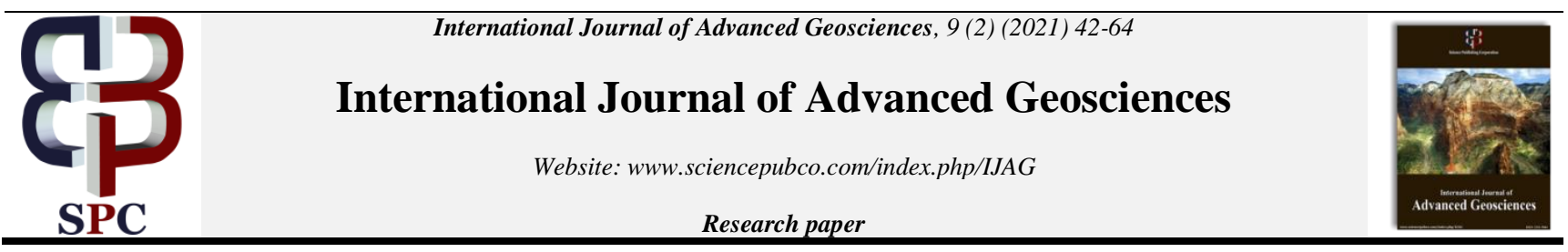

\title{
Petrography and geochemistry of the granitoids and associated volcanic rocks of the northern part of Kushaka and Birnin Gwari schist belts, NW Nigeria: implications for provenance and geological setting
}

\author{
Kehinde Oluyede $^{1 *}$, Garba Ibrahim², Umar Danbatta ${ }^{3}$, Paul Ogunleye ${ }^{4}$ and Urs Klötzli \\ ${ }^{1,2,3,4}$ Department of Geology, Ahmadu Bello University Zaria, Nigeria \\ ${ }^{5}$ Department of Lithospheric Research, University of Vienna, Austria. \\ "Corresponding Author's e-mail: olulekeoluyede@gmail.com
}

\begin{abstract}
The granitoids and the associated volcanic rocks of the northern part of Kushaka and Birnin Gwari schist belts were emplaced in the ca. $3.5-1.0$ Ga remobilized basement complex terrain composed of metasedimentary and metaigneous rocks that later underwent mediumto high-grade metamorphism during the Pan-African thermo-tectonic event. They comprise dominantly of diorite, granodiorite, granite, granite gneiss and basalt, and are product of metasomatism and injections. The diorite and granodiorite occur as paleosome and the granite as leucosome with the development of high temperature minerals, locally attaining granulite facie metamorphism. Plagioclase, biotite, hornblende, pyroxene and olivine fractionation played an important role during their genesis through fractional crystallization of basaltic magma and partial melting of older dioritic-granodioritic source rock in the deep crust which were themselves ultimately derived through fusion of mantle materials contaminated by continental crust and enriched by fluids derived from oceanic crust in an arc setting. Geochemical characteristics have revealed different chemical trends in granitoids and basalts. The granitoids are calc-alkaline, ferroan and magnesian, metaluminous and peraluminous in character. They also exhibit I- and S-type signatures with enrichment in LILE, radioelements (Th and $\mathrm{U}$ ), depletion in $\mathrm{Nb}, \mathrm{Sr}, \mathrm{P}$ and $\mathrm{Ti}$, high LREE fractionation factors $(\mathrm{La} / \mathrm{Yb})(1.05$ to 77.20$)$, and pronounced negative $\mathrm{Eu}$ anomalies $\left(\mathrm{Eu} / \mathrm{Eu}^{*}=0.34\right.$ to 1.10$)$. Similar patterns of spidergrams show that the rocks are genetically related and were emplaced in a volcanic arc and syn-collisional setting. The basalt is tholeiitic, metaluminous and high in $\mathrm{Fe}$ and $\mathrm{Mg}$ with relative enrichment in LILE, HFSE, low and near flat LREE and HREE, low fractionation [(La/Yb) $\mathrm{N}=1.4]$ with Eu/Eu* value of 1.10 . It is evidently a back arc cum mid-ocean ridge (MORB) basalt. The consistent decrease in the content of $\mathrm{MgO}, \mathrm{Fe}_{2} \mathrm{O}_{3} \mathrm{MnO}, \mathrm{CaO}, \mathrm{Sc}, \mathrm{Cr}$ and $\mathrm{V}$ of the basalt, diorites, granodiorites, and granites indicates continuous igneous crystallization process. It seems that extrusion of basaltic magmas from the sub-circular Kushaka Complex derived from subduction of oceanic crust resulted in complete change in the genesis of the magmas at the time, in this region. The granitoids and the basalt may have formed behind subducted Pan-African plate due to effects of compressional and tensional forces caused by oceanic plate roll-back which resulted to a zone of extension, parallel to the island arc. The granitoids present similar chemical characteristics to those in the other areas underlain by the basement complex and schist belts in the north and eastern parts of the Pan-African mobile belt, while basalts are similar to ophiolites and amphibolites in other schist belts of Nigeria forming a lateral continuation of the same mobile belt.
\end{abstract}

Keywords: Kushaka; Birnin Gwari; Basalt; Granodiorite; Granitoid; Island Arc.

\section{Introduction}

The western province of the Nigeria Basement Complex is characterized by narrow sediment dominated, N-S trending, low-grade schist belts which are separated from each other by migmatite-gneiss complex, intruded by Pan-African granitic plutons (Ajibade et al., 1987; Fig 1). These schist belts have been identified at Iseyin-Oyan, Ife-Ilesha, Igarra and Egbe-Isanlu and Obajana in the southwest (Rahaman, 1976; Odeyemi, 1977; Elueze, 1981; Annor, 1995; Olobaniyi, 2003; Okunlola and Okoroafor, 2009; Adegbuyi et al., 2017); the Kushaka Birnin Gwari, Malumfashi, Wonaka, Kazaure, Maru, Anka, and Zuru in the northwest (McCurry, 1976; Fitches et al., 1985; Turner, 1983; Danbatta, 1999; 2008b; Alaku et al., 2017); the Lokoja-Jakura, Toto-Gadabuike belts (Elueze, 1981; Okunlola, 2001) midway between the southwest and northwest; and Obudu schist belt recently highlighted in the southeast (Ekwueme \& Shing, 1987) (Fig. 2B \& C). The schist belts have been extensively migmatised to form migmatite gneisses, Pan-African Older Granites, syn-, late- and postcollisional magmatic intrusions of granitic to syenitic composition and closely associated metavolcanics occurring as mafic and 
ultramafic rocks such as ophiolite, basalt and amphibolite (Turner, 1983, Danbatta, 2008; Caby and Boesse, 2001; Mucke, 2005; Oluyede et al., 2021b).

In the earlier work by Truswell and Cope (1963) on Kushaka and Birnin Gwari Schist belts at least three major episodes of igneous intrusion have been recognised. The first episode was extensive migmatization. This was followed by the second episode with the intrusion of coarse-grained granodiorites and biotite muscovite granites, which also form the leucosome to the tonalitic or schistose paleosome. The last major plutonic activity led to the emplacement of unfoliated or weakly foliated, very coarse-grained to coarsely porphyritic granite and granodiorite that occur as elongated or oval shaped bodies cutting across the earlier phase of intrusion as well as the metamorphic rocks. Ajibade $(1979 ; 1980)$ investigated the structural and other relationships between the gneissic complex and the schist belts in the Zungeru/Minna area and confirmed the presence of two types of migmatites and gneisses which are believed to belong to two different ages. Various ages from Archaean to Pan-African have been assigned to the thermo-tectonic events in this area by earlier workers (Grant, 1972, 1978; Turner, 1983; Dada, 1989; Ajibade, et al., 2008; Adekoya, 1996; Annor, 1998; Danbatta, 2008; Goodenough et al., 2014). Age determinations on the granitoids show that they were emplaced during the late Precambrian to Early Paleozoic (750 - $450 \mathrm{Ma}$ ). However, granitic gneisses have yielded Rb-Sr ages of over 2000 My (Grant, 1970), making it difficult to distinguish early basement gneisses from foliated granitoids (Table 1). Turner (1983) reported that the Kibaran date on the Kushaka gneisses indicates basement reactivation, possibly associated with gneiss dome tectonics and may represent Kibaran plutonism. The focus of previous workers has been on field relations, structures geochronology, gold and rare metal mineralization, and therefore not much is known about the granitoids in the northern part of Kushaka and Birnin Gwari schist belts. This paper presents the results of petrographic and whole rock chemical analyses of basement complex granitoids and newly reported associated volcanic rocks in order to evaluate the chemical characteristics, provenance and tectonic settings of these rocks. It is a contribution to the understanding of the geodynamic environment of the granitoid magmatism in this sector of the Nigerian basement complex.

Table 1: Age Data on Some Granite and Migmatite Gneiss Host in the Nigerian Basement Complex

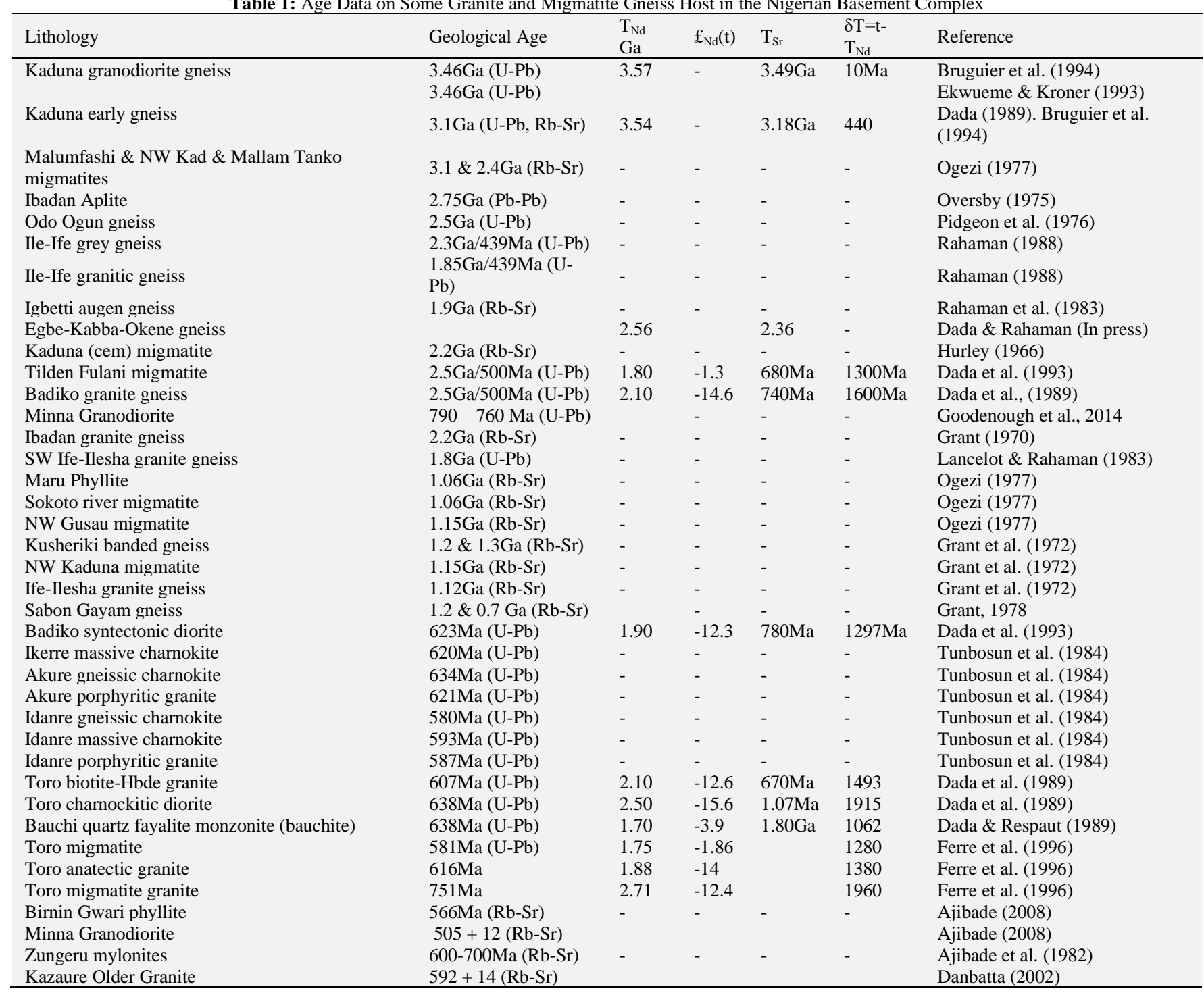

\section{Regional geology of Nigeria}

The Nigerian basement complex consists of three major rock units: (1) the Migmatite Gneiss Complex (MGC), a heterogeneous assemblage of predominantly amphibolite-facies migmatites, orthogneisses, paragneisses, and minor-basic to ultrabasic rocks (Rahaman 1988); (2) the Schist Belts, believed to overlie the MGC and consisting mainly of psammitic to pelitic metasediments with interlayered granite gneisses and rare amphibolites, interpreted as metavolcanics (Turner 1983); and (3) the Older Granites composed of tonalitic to 
granitic plutons and charnockites, strongly foliated to almost unfoliated, and considered to have been emplaced during the Pan-African orogeny (Tubosun et al., 1984). The intrusion of the "Older Granites" into the Migmatite Gneiss Complex during the pervasive and protracted Pan-African thermotectonic event has in many cases made it difficult to distinguish them.

In Nigeria, two main terranes, Western and Eastern are separated by a $500 \mathrm{~km}$ long N-S lineament (Ferre et al., 1996; Ananaba and Ajakaiye, 1987) (Fig. 1). The Western terrane is characterized by (i) an Archaean basement and (ii) a cover of synformal schist belts corresponding to a gold metallogenic province, banded iron formations (BIFs) and greenstone-type deposits (Woakes et al. 1987). By contrast, the Eastern terrane is characterized by high-grade metamorphic rocks and a tin and uranium metallogenic province (Woakes et al. 1987; Onyeagocha \& Ekwueme 1990). The Western Nigeria terrane has been the focus of several studies in which continuity of the major structures from north to south, Archaean $\mathrm{U}-\mathrm{Pb}$ zircon ages and numerous $\mathrm{Nd}$ model ages older than 2.7 Ga have been reported (Caby, 1989), Bruguier et al., 1994; Dada, 1998). The Proterozoic cover in this terrane consists mostly of monocyclic metasediments of greenschist facies metamorphic grade (e.g. Fitches et al., 1985) and amphibolite facies grade in the south (Caby, 1989). Voluminous granitic plutons and widespread migmatization, both dated between 620 and $580 \mathrm{Ma}$, attests that this region has been substantially affected by tectono-metamorphic events of Late Neoproterozoic age (Tubosun et al., 1984; Dada, 1998).

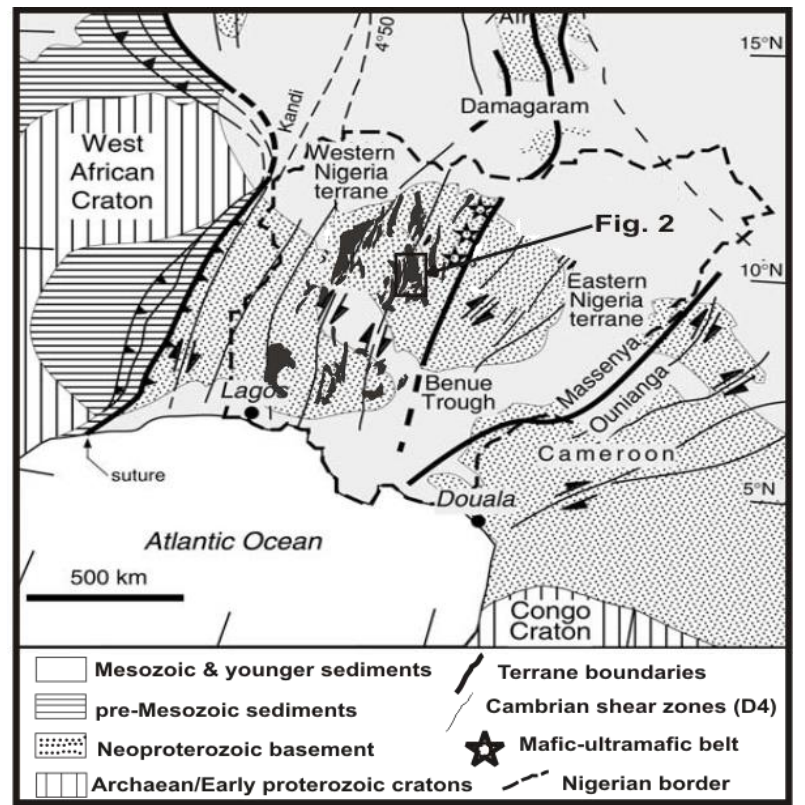

Fig. 1: Geological Sketch Map of the Nigeria Province Showing the Neoproterozoic Terrane Amalgamation between the Cratons of West Africa and Congo (Modified After Ferre Et Al., 1996).

Geochronological studies have shown that the Nigerian basement is polycyclic and composed rocks of Liberian (Archaean) $3400+200$ Ma, Eburnean (early Proterozoic) 1200 \pm 200 Ma, Kibaran (middle Proterozoic) 1100+200 Ma and Pan-African (late Proterozoic) $600 \pm 150 \mathrm{Ma}$ (Table 1). The Archean-Proterozoic is a distinct crustal initiation event with significant crustal growth, which can be correlated with the Birrimian system on the West African Craton (Dada et al., 1998). This is seen from the orthogneisses of Kaduna in north central Nigeria (Dada, 1989; Dada et al., 1993) with Nd model ages that overlap U-Pb zircon crystallization ages (Table 1). The Eburnean orogeny is regarded as the last major orogenic event to have affected the West African craton on a regional scale (Wright et al. 1985). Although the Eburnean event was accompanied by widespread granite magmatism and greenschist facies metamorphism, there is no confirmed evidence for the occurrence of Eburnean sediments in Nigeria. Kibaran relics in West Africa are only scattered, discontinuous and generally overprinted by Pan-African structures and magmatism (McCurry, 1976). The Kibaran event with its limited localized effect is not considered to have been a major tectonic event in Nigeria, whereas the most obvious effect of the widespread PanAfrican reworking in Nigeria is the emplacement of large volumes of granitoids and the resetting of mineral ages in virtually all rock types in the basement (Ajibade et. al., 1987; Rahaman, 1988; Ogezi, 1977; Cooray, 1974; Ekwueme and Kroner, 1994; Brougier et al., 1994; and Dada et al., 1993). The Pan-African orogenic imprints in the Nigerian Basement Complex are characterized by low to high grade metamorphism, folding, faulting and widespread granite plutonism. These granitoids termed the "Older Granites" in Nigeria, so named by Falconer (1911) to differentiate them from the Mesozoic tin-bearing Younger Granite suites, which are volcanic/granitic ringcomplexes in the Jos Plateau area, have been dated severally at 750-500Ma (van Breemen et al., 1977; Rahaman et al., 1983; Fitches et al., 1985; Ferre et al., 1998; Ekwueme \& Kroner, 1998).

Geochronologically, these granitoids are comparable to those in the Borborema province which has reported to be associated with the Brasiliano Orogeny (Long et al., 2005; Guimaraes, 2004). These granitoids are composed of tonalitic to granitic plutons and charnockites, strongly foliated to almost unfoliated and with wide range of composition from granite through granodiorite, quartz-monzonite, and tonalite to syenite (Rahaman, 1976; Tubosun et al., 1984). Similar granitic rocks have also been studied in various parts of the basement complex of northern Nigeria (Olarewaju \& Rahaman, 1982), Jebba area (Okonkwo \& Winchester, 2004), Obudu Plateau, southeastern Nigeria (Ukwang and Ekwueme, 2009), Kabba-Lokoja area (Ezepue and Odigi, 1993), among others. Granite magmatism is commonly associated with several tectonic settings and various stages during orogenic evolution (Pitcher, 1983; Pearce et al., 1984; Whalen et al., 1987; Maniar \& Piccoli, 1989; Frost et al., 1999). The work of Kroner et al., (2001) confirms migmatitic orthogneiss of granodioritic composition from Kabala in Kaduna (close to the study area) in northern Nigeria which contains elements of an Early Archean basement complex that survived the Pan-African orogeny that remobilized large parts of the Nigerian crust. Debate exists on whether the PanAfrican event was so pervasive that it completely isotopically rehomogenized all older rocks, thereby obliterating all traces of earlier tectono-metamorphic events. However, Grant (1978), Mullan (1979), Ajibade (1988), Fitches et al. (1986), and Ekwueme (1987) argued that the Pan-African orogeny did not overprint all traces of earlier events. All the ages determined from the Pan-African granites show consistency, and correlates well in both north and southwest. 


\section{Geology of the study area}

The study area covers a total area of 2,809 square kilometers and lies in the north western part of Nigeria comprising part of Kushaka and Birnin Gwari schist belts. It falls within 1:100,000 Kushaka Sheet 122 and bounded by latitudes $10^{\circ} 30^{\prime} \mathrm{N}$ and $11^{\circ} 00^{\prime} \mathrm{N}$ and longitudes $6^{0} 35^{\prime} \mathrm{E}$ and $7^{0} 00^{\prime} \mathrm{E}$. The area is underlain predominantly by five main lithologies: (i) Migmatite-Gneiss-Quartzite suite represented by dioritic, granodioritic, granite and granitic gneisses with fissile and ferruginous quartzites and banded iron formation (BIF); (ii) the schist belts represented by the Kushaka graphite and sulphur bearing staurolite, biotite and muscovite quartz schist and in places inter-banded with iron formations; (iii) Birnin Gwari schist comprising staurolite-biotite quartz schists (iv) the Kushaka Gneiss Complex represented by extrusive basalts, staurolite and muscovite gneiss and banded iron formation (BIF) and (v) syn- tectonic and late- orogenic biotitehornblende syenite (BHS) and biotite-hornblende granite (BHG) in the Kushaka schist belt and biotite muscovite granite (BMG) in the Birnin Gwari schist belt area (Fig. 2D).

\section{Analytical methods}

Thirty eight samples of the granitoids comprising 8 Kushaka granite; 8 Birnin Gwari granite; 15 Basement Complex granitoid; 5 Kushaka Gneiss Complex granitoid and 2 basalt were selected for petrographic investigations at the Department of Geology, Ahmadu Bello University, Zaria using a petrological research microscope. Estimation of modal composition of each rock type was done on thin the sections made from the rocks using the JMicrovision software of Nicholas Roduit version 1.2.7. (2002-2008). About $1 \mathrm{~kg}$ each of thirty rock samples selected out of the lot was broken with a hammer, crushed into smaller pieces with a jaw-crusher and pulverized into fine powder in a disc mill. Each of the pulverised sample was thoroughly homogenized to obtain a representative portion for chemical analyses. Whole-rock geochemical analysis of the samples was carried out at the Department of Lithospheric Research, University of Vienna, Austria using XRF Flourescence Analysis. Major elements composition of the rock samples was determined by fused bead method on calcined rock powder fused with lithium tetraborate as flux to form a glass bead while the trace elements analysis was done by pressed pellet method directly on the crushed and milled rock powder mixed with polyvinyl alcohol as a binding agent. Analysis of the REE was carried out using a lithum metaborate/tetraborate flux in a platinum crucible and fused samples poured into a platinum mold to create a homogenous glass disk and then analysed with PHILIPS PW2404 sequential X-ray spectrometer at the MSALABS Langley, British Columbia, Canada. The X-ray fluorescence instrumentation comprises a super-sharp end-window tube with a Rh-anode and a programmable $4 \mathrm{~kW}$ generator $(60 \mathrm{kV}$ max., $125 \mathrm{~mA}$ max.; iso-Watt-switching), with accompanying PANalytical software.

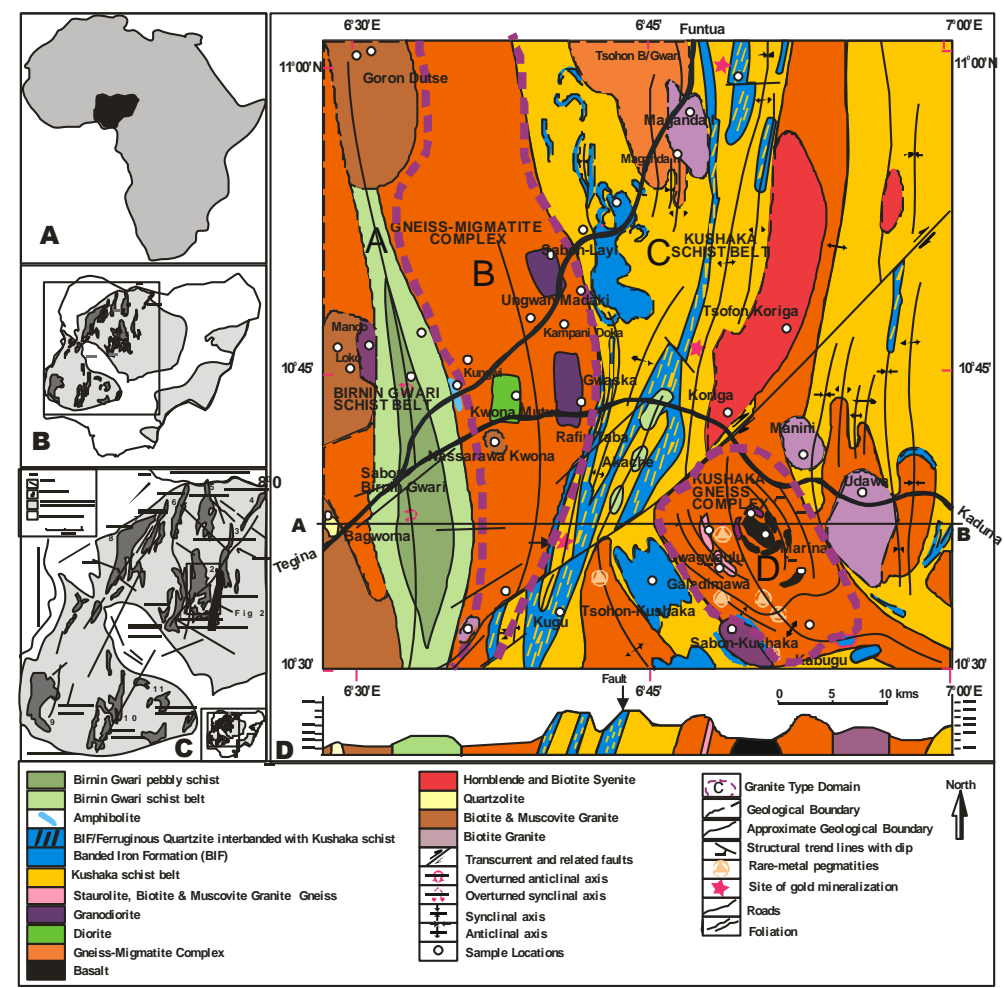

Fig. 2: Geological Map of Northern Part of Kushaka and Birnin Gwari Schist Belts (Sheet 122) Modified After Truswell and Cope, (1963).

\section{Field relations and petrography of the granitoids and associated volcanic rocks}

The granitoids in the study area have been classified based on the litho-petrological unit and mode of occurrence into four main groups namely: (i) Basement Complex Granitoids (BCG), (ii) The Kushaka Gneiss Complex Granitoids (KGC) (iii) The Kushaka Schist Belt Granite (KG) and (iv) The Birnin Gwari Schist Belt Granite (Fig. 2).

\subsection{Basement complex granitoids (BCG)}

Granitoids of the basement and Kushaka gneiss complex occur as paleosome of dioritic, granodioritic, compositions and leucosome of granitic composition; tonalite, granite and granite gneiss (Fig. 3). The dark grey paleosome and light grey leucosome are medium to coarse grained migmatitic rock with alternating dark and light bands respectively, varying from 0.5 to $15 \mathrm{~m}$, and are aligned parallel to the 
regional foliation direction. They are found in localities around Ungwan Madaki, Gwaska and Kwona Mutua. Paleosomes are dark coloured pyroxene bearing rocks. Microscopically it consists essentially of augite (55\%), and accessory biotite (5\%) and iron-oxide (5\%) set in groundmass of quartz (25\%) and plagioclase feldspars (10\%). Quenched augite crystals are elongate, curved and branching in subparallel alignment, others occur as group of branching and diverging needles (Fig. 4). The leucosome occurs commonly as cross cutting dykes marked by dextral displacement relative to one another. Under the microscope, the leucosome is revealed to be composed of Kfeldspar (40\%), quartz (30\%), plagioclase (10\%), biotite (10\%) and iron-oxide (5\%) with accessory minerals being apatite and magnetite. Tonalite is well exposed along River Rafin Magami, and occur as boulders and whale backs which are traceable westward for few kilometers from the bridge across the Birnin Gwari - Funtua road, north of Sabo-Layi village. It is a fine to medium grained rock, grey in colour and weakly foliated tonalitic and granodioritic in composition. Microscopically, it consists of orthoclase (5\%), plagioclase (60\%), quartz (20\%), biotite (10\%), orthoclase (5\%) and pyroxene $(5 \%)$ as major minerals and accessory minerals comprising iron-oxide (haematite and magnetite) and apatite (Fig. 4). Subhedral to euhedral quartz together with vermicular intergrowth of k-feldspar and plagioclase exhibits mykeritic texture. Tabular and zoned orthoclase (perthitic) and plagioclase $\left(\mathrm{An}_{15-20)}\right.$ are in equal proportion. The plagioclase exhibits simple twinning. The mafic minerals comprising biotite, pyroxene, olivine and iron-oxide, occur in clusters. Granitoids occur as leucosome injection component in the granodiorite and as coarse-grained to porphyritic paleosome component in Ungwan Madaki and Gwaska areas (Fig. 3). They consist essentially of quartz (40\%) and K-feldspar (40\%), with biotite (15\%) as ferromagnesian mineral. Quartz occurs as euhedral to subhedral medium-grained crystals between the feldspar crystals which exhibit mykeritic intergrowth. K-feldspar consists of orthoclase (perthitic and micro-perthitic) and microcline with cross hatch twinning. The feldspars also contain dense mass of clay and mica minerals as alterations (Fig. 4).
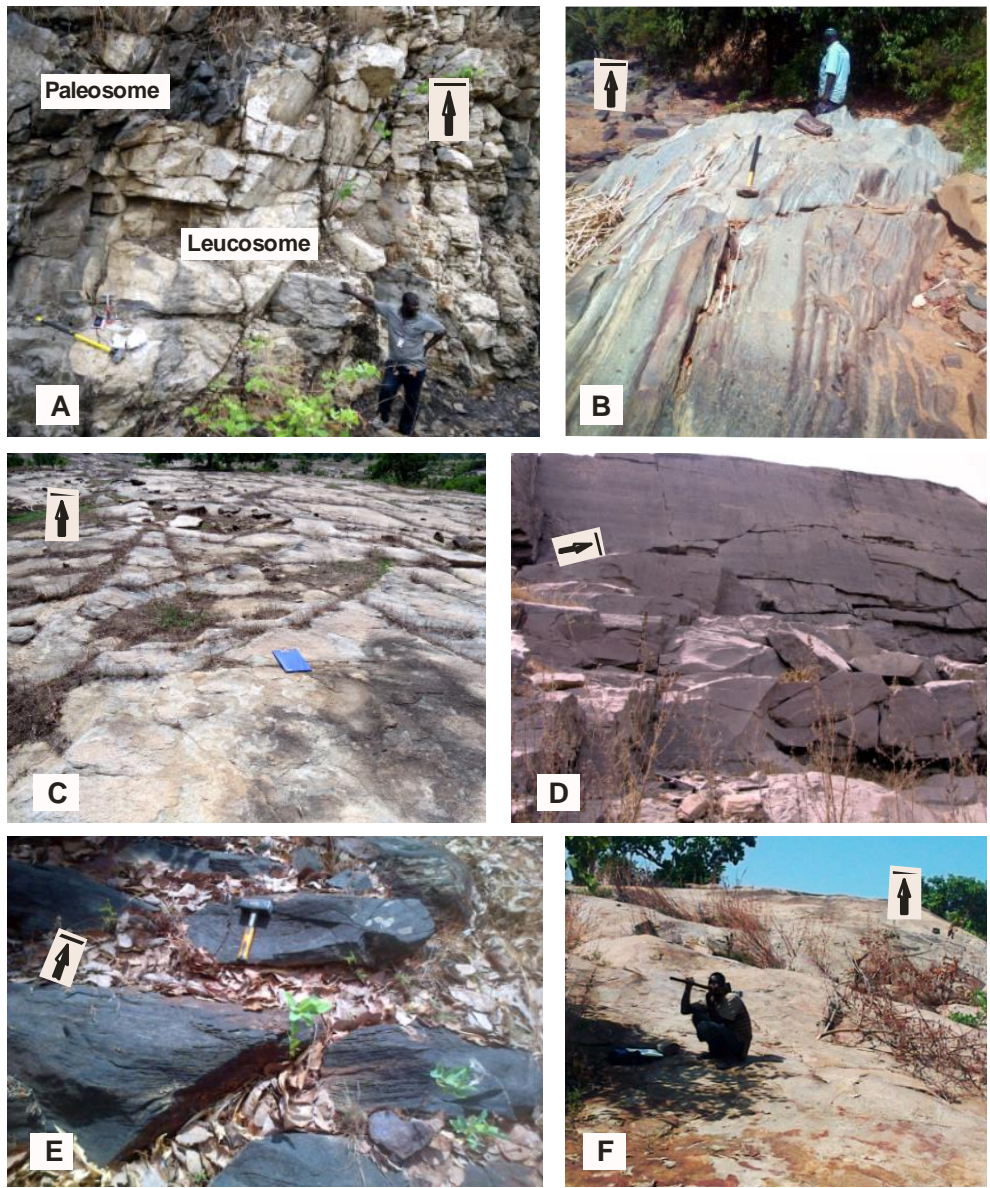

Fig. 3: (A) Field Occurrence of Porphyritic and Granitic Leucosome and Paleosome in Gwaska (N10 4340 E 6043 34); (B) Granodioritic Gneiss Outcrop in Marinai (N $10^{0} 3327$ E $6^{0} 51$ 31) in the Kushaka Gneiss Complex; (C) Biotite Granite in Manini (N10 4077 E $6^{0} 51$ 94); (D) Kampani Doka Granitic Gneiss Outcrop Used as Quarry (N10 4510 E $6^{0} 36$ 13); (E) Marinai Basalt in Kushaka Gneiss Complex (N10 33' 27”' E $6^{0} 51$ 31) And Biotite and Muscovite Granite In Mando (N10 4327 E $\left.6^{0} 3374\right)$.

Granite gneisses occur as prominent outcrops and as low-lying whale back exposures along river channels in Kampani Doka and Kugu areas. In Kampani Doka area, a prominent outcrop (about 520m high) is formed by a fine grained, weakly foliated equigrannular pink to reddish brown rock, being quarried for constructional material (Fig. 4B). Microscopically, the reddish-brown rock is composed of quartz $(30 \%)$, orthoclase $(25 \%)$ muscovite $(25 \%)$, iron-oxide $(10 \%)$ and biotite $(5 \%)$ in a groundmass of K-feldspars, muscovite iron-oxide and biotite. The low-lying highly foliated outcrops are found in Kampani Doka (along the tributaries of Kusheriki river channel), Ungwan Wakili and Kugu to the south. The granite gneisses are fine grained, grey coloured rock. In thin section the rock is composed of phenocryst of quartz (30\%), K-feldspar (25\%) biotite (25\%) and iron-ore (5\%) set in groundmass composed of polygonal quartz, feldspar, biotite and iron-ore. Accessory minerals include apatite, titanite and magnetite.

\subsection{The Kushaka gneiss complex (KGC)}

The Kushaka Complex is a sub-circular plutonic rock and occurs in south-west of the Kalangai transcurrent fault where it truncated the Kushaka metasediments. At the sub-circular outline are series of low lying extrusive basalt and granodiorite (Fig. 3). The boundary with the basalt was observed anywhere due to highly weathered state of rock and therefore the contact relationship cannot be clearly clarified; 
and high level $(500-600 \mathrm{~m})$ granite gneiss consists of biotite-staurolite and muscovite bearing granitic gneisses in the outer part of the sub-circular complex. Other rock types of the complex include Banded Iron Formations (BIFs) and rare metal-bearing pegmatites. The KGC is highly fractured with brittle deformation and the central part extensively weathered.

Outcrops of dark, dense, fine- to medium-grained, dark-coloured basalt occur in Marinai and Kabugu area. The rock is granular in texture, highly fractured with block jointing. It is composed essentially of anhedral to subhedral glomerocryst to small prismatic crystals of pyroxene $(50 \%)$, with preferred alignment in the groundmass. Olivine $(10 \%)$ phenocrysts are subhedral and pale brown in colour under plain and cross polarized light and are closely associated with iron-ore. The finer prismatic crystals of this mineral swarm around the glomerocrysts which stand out from the groundmass of needle-like euhedral plagioclase (10\%), pyroxene, quartz (20\%), and other accessory titanite, apatite and garnet (Fig. 4).

Granodiorites in Marinai are exposed along the river channels. They are medium grained dark coloured plutonic rock characterized by wide $(10-15 \mathrm{~cm})$ silicified and iron-rich silica veins in some cases traceable for over $100 \mathrm{~m}$ with width and trending $60^{0} \mathrm{NE}$. In thin section, this rock consists of pyroxene $(30 \%)$, quartz $(25 \%) \mathrm{K}$-feldspar $(25 \%)$, plagioclase $(10 \%)$ and iron-oxide $(5 \%)$ set in groundmass of quartz, pyroxene, and plagioclase with small proportion of iron-oxide (Fig. 4). Accessory minerals are titanite, apatite, garnet, zircon and magnetite. They are classified modally as quartz diorite, tonalite and granodiorite (Fig. 4A).

The staurolite-muscovite and staurolite-biotite granite gneiss consists predominantly of staurolite porphyroblast (40\%), iron-oxide (5\%), quartz $(20 \%)$, K-feldspar (10\%), biotite (15\%) and muscovite (10\%) embedded in quartz, feldspar and muscovite matrix. Staurolite occurs as pale brown and euhedral six-sided elongated crystals characterized by quartz inclusions and also dotted with iron-ore crystals (Fig. 4).

\subsection{The Kushaka schist belt granite}

The granite plutons that intruded Kushaka metasediments are found in Maganda, Nasarawa- Kwona, Koriga, Manini, Udawa, SabonKushaka and Kugu. They are biotite-hornblende syenite; biotite, and biotite-muscovite granite and granodiorite. These intrusions form N-S excellent oval and elongated bodies of whaleback with moderate and high relief on either side of the transcurrent Kalangai fault. One major feature is their occurrence along the boundary of basement migmatite gneisses and Kushaka and Birnin Gwari schist belts (Fig. 2). Macroscopically, the colour ranges from light to dark grey, grayish yellow, grayish brown to light (iron) red. They also occur as porphyritic, coarse porphyritic and medium grained, and are generally devoid of pervasive foliation, but intense deformation responsible for $S_{1}$ foliation has caused some varieties to develop slight banding, with the dark minerals forming mafic microgrannular enclaves. These enclaves are dark grey to black in colour and occur in near circular shape of 3-5cm in diameter (Fig. 3), and consist of biotite, hornblende and iron-oxide.

Syenite occurs as N-S trending elongated outcrop; medium- to coarse-grained, with hypidiomorphic texture and mafic enclaves. Two varieties are easily recognized in the field. The first one in around Koriga town is iron-rich and is typified by its more pinkish brown colour with fragmented and observable boulders; some stacked on top the other, suggesting a disturbed terrain. Microscopically, the rock consists of quartz (20\%), K-feldspar (35\%), hornblende (20\%), biotite (10\%), plagioclase (5\%) and iron-oxide (5\%). Dominant mafic hornblende and biotite are slightly aligned in foliation direction. Plagioclase (An 35-40) occurs as platy euhedral phenocryst with albite twinning and fine mica impurities. Accessory minerals include zircon, titanite, magnetite, apatite and iron ore inclusions (Fig. 5).

Granite constitutes wide range of rock pervading the whole of the schist belt. Rocks range from medium and coarse-grained to porphyritic, gray to grayish dark and grayish brown in colour. Maganda granite outcrop occur as coarse grained light grey coloured biotite-muscovite granite and medium grained granular and pink coloured biotite granite. Constituent minerals are quartz (30\%), Kfeldspar $(25 \%)$, plagioclase $(30 \%)$, biotite $(10 \%)$, muscovite $(5 \%)$ and accessory titanite and hematite minerals $(5 \%)$. Granite in Udawa area occur as low lying whale back outcrop usually devoid of pervasive foliation and intruded both the basement gneiss and the Kushaka schist. This is a light grey colour, mediun to coarse grained biotite-bearing granite with no preferred orientation of the slightly pinkish feldspar. Microscopically, it consists of quartz (35\%), biotite (10\%), almost equal amount of platy, tabular phenocrysts of K-feldspar (perthitic orthoclase and microcline) (25\%), plagioclase (An45) (25\%) with zoned inclusion of dense clay minerals and interwoven replacing each other producing a vermicular, wormlike and mykeritic structure. biotite (10\%). Granite outcrop north east of Manini village is a large massive exposure of $632 \mathrm{~m}$ elevation, extending further to Kufara and Manini Kan Hauwa. It is a medium to coarse grained foliated grey granite, characterized by block jointing (Fig. 3). Identifiable minerals are coarse grain, grey quartz, whitish to grey medium grained feldspars and dark coloured and medium grained biotite and muscovite. Petrographically, mineral associations are euhedral quartz (30\%), euhedral and platy K-feldspar (25\%) comprising orthoclase and microcline, plagioclase (25\%), biotite (15\%) and muscovite $(5 \%)$. Phenocryst of K-feldspar shows micro perthite, microcline with tartan and cross hatch twinning with blebs of biotite and other quartz and tiny dense mica inclusions (Fig. 5); accessory minerals are apatite and zircon. Granite outcrops in Kugu area are low lying and intruded the Kugu quartz schist ridge interbedded with Banded Iron Formation (Fig. 1). It's a medium grain, weakly foliated rock, with pink to reddish brown feldspars, grey quartz and dark biotite minerals. It consists of quartz (25\%); K-feldspar (30\%) and plagioclase $(25 \%)$ are welded together with fine and dense clay minerals inclusion, biotite (10\%) and iron-ore (5\%) (Fig. 5), patches of K-feldspar show vermicular intergrowth with quartz.

Granodiorite pluton occurs as medium to coarse porphyritic in Sabon-Kushaka area (Fig. 3), with whitish to pinkish colour feldspar porphyry $2-6 \mathrm{~mm}$ in diameter. Biotite shows planar orientation in a $330^{\circ} \mathrm{NW}$ foliation direction. Microscopically, they are composed of quartz $(25 \%)$, K- feldspar $(25 \%)$, plagioclase $(25 \%)$, biotite $(15 \%)$; accessory minerals include ilmenite, haematite and apatite hedged between orthoclase (Fig. 5). Marinai granodiorites are medium grained dark foliated coloured granite gneisses with thin bands of light felsic and dark coloured mafic minerals confined to the river channels. They are characterized by silicified and iron-rich silica veins. The granite, syenite and granite gneiss are classified modally as monzogranite and granodiorite (Fig. 6B).

\subsection{The Birnin Gwari schist belt granite}

The granite plutons intruded both the Migmatite-Gneiss-Quartzite suite and the Birnin Gwari schist in Gworon Dutse, Mando, Loko, Bagwoma, Birnin Gwari and Kugu. These intrusions form N-S excellent oval and elongated bodies of whaleback with moderate and high relief on either side of the transcurrent Kalangai fault (Fig. 1).

Granodiorite alongs the Birnin Gwari/ Mando axis is restricted to the contact zone between the Birnin Gwari staurolite bearing quartz schist and Mando biotite and muscovite granite. This is a medium grained rock characterized by light grey granitic inclusions in the lightbrown coloured rock slightly aligned in the N-S foliation direction. Under the microscope, it is a coarse to medium grained rock 
consisting of quartz (30\%), K-feldspar (30\%), plagioclase (15\%), biotite (15\%), and accessory minerals (5\%). Other accessory minerals are titanite, magnetite and apatite.

Granite occurs as N-S trending isolated plutons and low whale back outcrops on the edges of the Birnin Gwari schists in places with sharp contacts with the schists and granitic gneisses (Fig. 1). Granite in Goron Dutse consists of four individual closely spaced plutons, with high relief $(550 \mathrm{~m})$, and intruded the Birnin Gwari metasediments at the northwestern fringes. Two varieties are coarse porphyritic and fine- to medium grained equigrannular types, occurring closely together and the latter as dykes and veins in the former. Under the microscope, the coarse porphyritic rocks show quartz (35\%), K-feldspar (35\%), muscovite (5\%), biotite (15\%), plagioclase (5\%) and iron-oxide (5\%). Accessory minerals include magnetite, illmenite, titanite and apatite. Granite in Mando and Loko border both the gneisses and Birnin Gwari metasediment. The contact zones with the metasediments are sharp with chilled margins as observed west of Mando village stretching for about $1 \mathrm{~km}$. It is a fairly elevated granite outcrop $(443 \mathrm{~m})$ in places dissected by River Ikanga. Observable minerals include pinkish to milky feldspars, silvery muscovite flakes, and black to brownish biotite, in places slightly weathered and brownish green muscovite. The contact zone with Birnin Gwari staurolite quartz schist extends hundreds of meters and is characterized by granitic dyke intrusion with chilled margins. Petrographically, quartz $(30 \%)$ occurs as subhedral phenocryst together with plagioclase $(5 \%)$, orthoclase $(20 \%)$ and microcline $(20 \%)$, as well as medium grain euhedral crystals, closely interlocked with each other and with biotite (10\%) and muscovite (10\%) forming part of the groundmass. Accessory minerals include magnetite and apatite. Granite in the Nasarawa Kwona area form a low-lying outcrop, extending southward along Birnin Gwari - Kaduna road for about $2 \mathrm{~km}$ and intersected by river Faleli and tributaries of Kogi Kusheriki. It's a medium grained, pink coloured rock. Macroscopic observation shows the pink feldspar dominating the grey colour quartz; dark colour biotite and muscovite minerals are visible. Microscopically, the rock consists of quartz (35\%), K-feldspar (35\%), biotite $(10 \%)$, plagioclase $\left(\mathrm{An}_{30}\right)(5 \%)$ and muscovite $(5 \%)$ minerals. Iron-ore occur as assessory mineral and dotted in the matrix making up 5\% of the rock. Granite outcrop in Kugu area is a low lying medium grain, weakly foliated rock, with observable hand specimen showing pink to reddish brown feldspars, grey quartz and dark biotite minerals (Fig. 1). It consists of quartz (25\%), K-feldspar (30\%), plagioclase (25\%), biotite (10\%) and iron-ore (5\%). Patches of K-feldspar show vermicular intergrowth with quartz. Porphyritic biotite granite in Gwaska occur as porphyritic leucosome that intruded the Gwaska paleosome, comprising quartz (40\%) and K-feldspar $(40 \%)$, with biotite $(15 \%)$ as ferromagnesian mineral. Accessory minerals include apatite and magnetite. Quartzolite forms an isolated outcrop northwest of Bagwoma dam. It's a light-coloured rock with grey, white, milky and reddish brown colours and coarse grain fibroblastic texture; with preferred mineral banding $\left(360^{\circ} \mathrm{NS}\right)$, light brown to reddish brown biotite and hornblende. Petrographically, the rock consists of quartz (60\%), K-feldspar (10\%), hornblende (15\%), and biotite (10\%) strongly aligned. Observable alteration is seritization where K-feldspar is altered to an aggregate of finely divided white mica. Hornblende is anhedral, lath-like and elongated with pale brown \& reddish-brown crystals (Fig. 5L). Biotite occurs as needle-like mineral stacked between the orthoclase polygons. Accessory minerals are opaque inclusions in the hornblende and plagioclase. The granite and granite gneiss are classified modally as syenogranite and quartzolite as quartz rich granitoids (Fig. 6C).
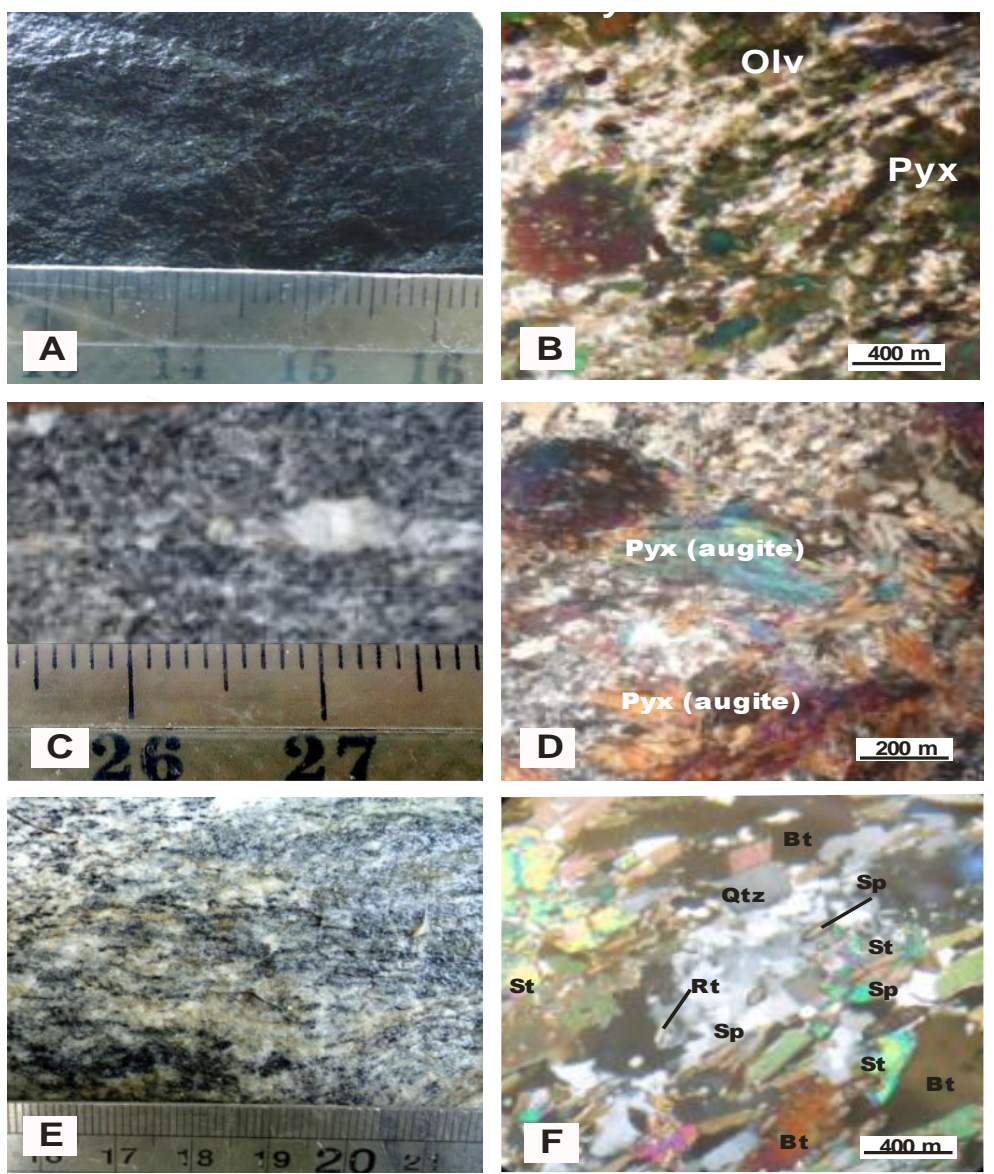

Fig. 4: Hand Specimen and Photomicrograph of Marinai Basalt; Ungwan Madaki Paleosome; Sabo-Layi Tonalite, All of the Basement Complex and Gwagwaulu Granite Gneiss of the Kushaka Gneiss Complex in the Northern Part of the Kushaka and the Birnin Gwari Schist Belts. 

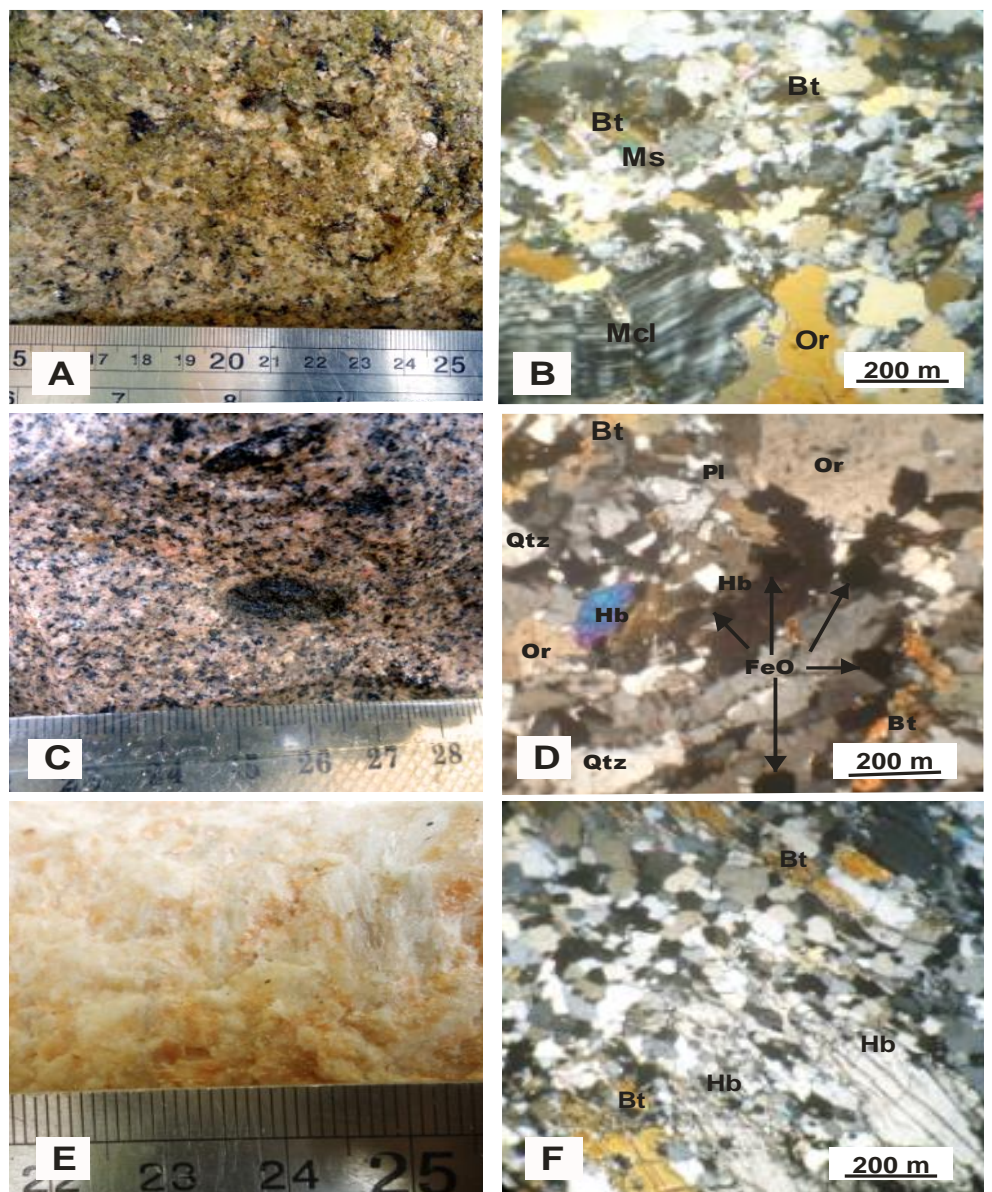

Fig. 5: Outcrop, Hand Specimen and Photomicrograph of Koriga Syenite; Maganda Granite in Kushaka; and Mando Granite and Bagwoma Quartzolite in the Birnin Gwari Schist Belts. Mcl=Microcline, Bt=Biotite,Ms=Muscovite, $\mathrm{Hb}=$ Hornblende, Or=Orthoclase.

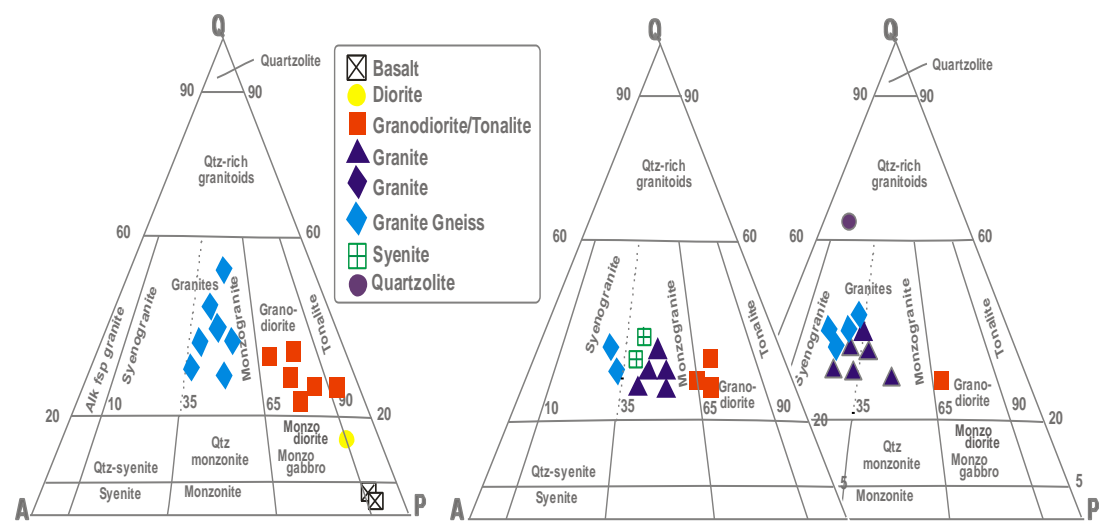

Fig. 6: Modal Classification Diagrams of the Granitoids in the (A): Basement and Kushaka Gneiss Complex; (B): Kushaka and (C): Birnin Gwari Schist Belts (After Streckeisen, 1976).

\section{Geochemistry}

\subsection{Rock classification}

The plutonic rocks in the study area with exception of samples KSy1 and KSy2, which are straddled between syenite and quartz monzodiorite show sub-alkaline affinity. The granitoids generally plot in the field of syenite/quartz monzodiorite, granite, quartzolite, granodiorite and diorite on the $\mathrm{SiO}_{2}$ vs $\mathrm{Na}_{2} \mathrm{O}+\mathrm{K}_{2} \mathrm{O}$ diagram (after Middlemost, 1985) (Fig. 7 A). The volcanic rock plots in the field of basalt, in agreement with petrographic characteristics (Fig. 7B). On the normative Ab-An-Or triangle of O'Connor (1965) diagram the rocks also plot in granite, granodiorite and quartz monzonite fields. The granites, syenites, quartzolite and granite gneisses plot in the granite field, granodiorites in the granodiorite field and diorite in quartz monzodiorite field (Fig. 8A). The chemical feature of these rocks as highlighted is attributed to mobility of $\mathrm{Na}$ and $\mathrm{K}$ during hydrothermal alteration. The volcanic rocks plot in the High-Fe and High-Mg tholeiite basalt field (Fig. 8B). 

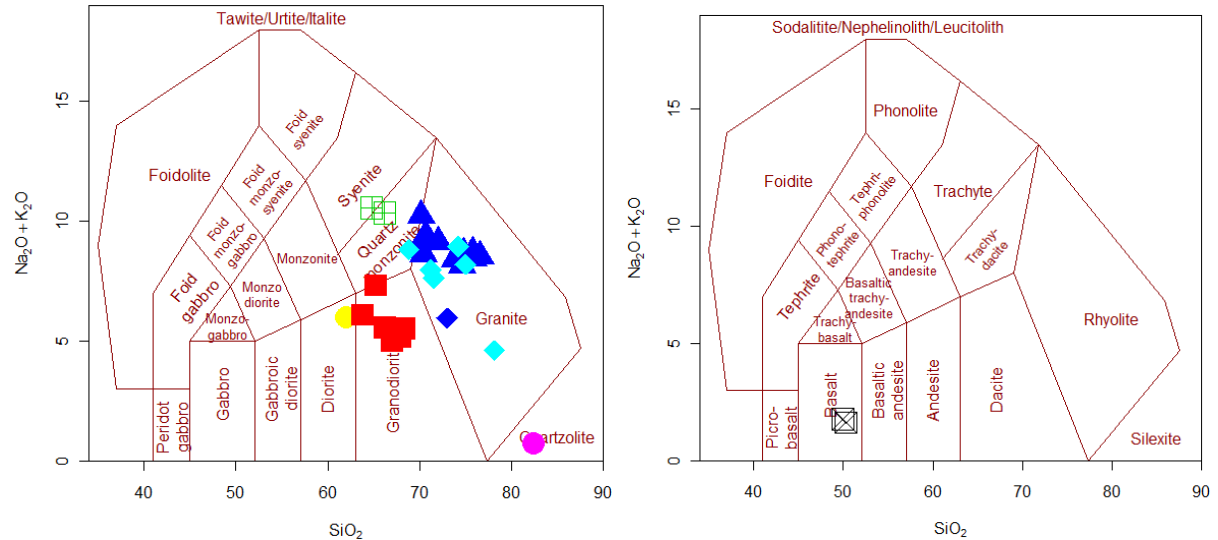

Fig. 7: (A): $\mathrm{Sio}_{2} \mathrm{Vs} \mathrm{Na}_{2} \mathrm{O}+\mathrm{K}_{2} \mathrm{O}$ Diagram (Middlemost, 1985) With Nomenclature of the Granitoids As Granites, Grandorites, Diorite, Syenite and Quartzolite; (B): As Basalt, Distinguishing Them As Subalkaline Magmatic Series (After Cox Et Al., 1979) (Symbols as in Fig. 6).

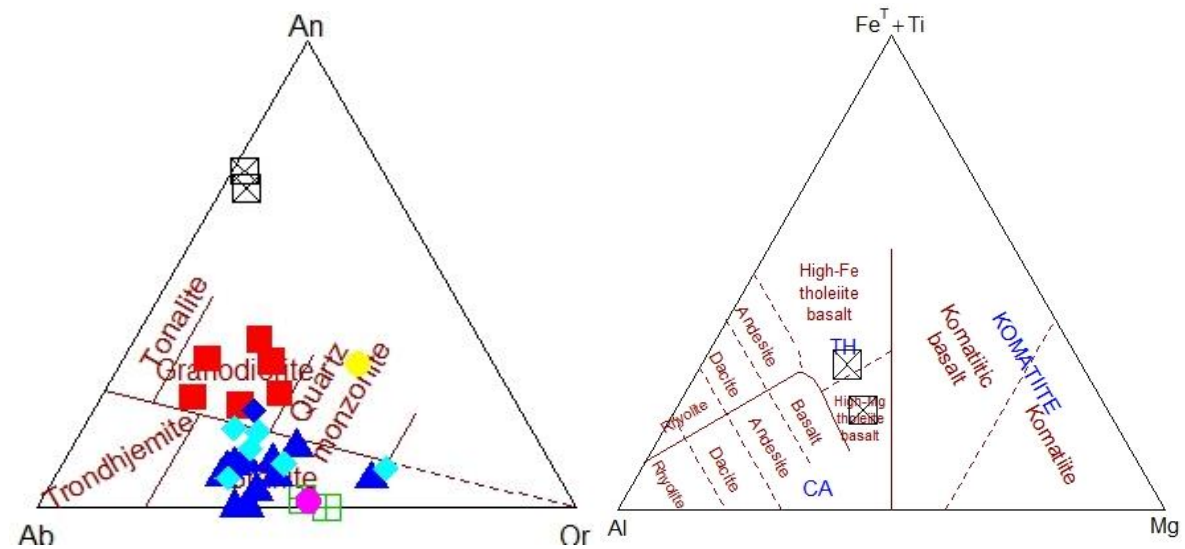

Fig. 8: (A) Normative An-Ab-Or Diagram Showing the Distribution of the Granitoids in Granitic to Granodioritic and Quartz Monzonite Field (After $\mathrm{O}^{\circ}$ Connor, 1965) and And Al- Fe+Ti-Mg of Jensen (1976) Showing Basalts are High Fe and Mg Tholeiite Basalt. (Symbols as in Fig. 6).

\subsection{Major elements}

Granitoids in the Kushaka and the Birnin Gwari schist belts display marked variation in the abundance of some major elements. Silica $\left(\mathrm{SiO}_{2}\right)$ is in the granite generally ranges from 60.77 to $82.42 \mathrm{wt} \%$. The wide range in the silica composition suggests diverse protoliths of the rocks. Enrichment in Mg and Fe oxides correlates positively with their high contents of mafic minerals (biotite, hornblende and pyroxenes). Most of the major elements display good correlation with silica $\left(\mathrm{SiO}_{2}\right)$ indicating normal igneous trend (Table 2) with silica contents in the range of $60.77-66.81 \mathrm{wt} \%$ for diorite and granodiorites and $64.02-82.42 \mathrm{wt} \%$ for granite. They are generally enriched in $\mathrm{TiO}_{2}\left(0.13\right.$ to 0.57 wt \%), $\mathrm{Fe}_{2} \mathrm{O}_{3}(4.07$ to $7.15 \mathrm{wt} \%), \mathrm{MgO}(1.11$ to $2.68 \mathrm{wt} \%)$ and $\mathrm{CaO}(2.23$ to 4.38 wt \%). Basalt on the other hand has lower $\mathrm{SiO}_{2}$ value in the range of $49.56-49.72 \mathrm{wt} \%$ and is more enriched in $\mathrm{TiO}_{2}(0.7-1.89$ wt $\%), \mathrm{Fe}_{2} \mathrm{O}_{3}(10.14-13.12 \mathrm{wt} \%), \mathrm{CaO}$ $(11.75-12.65 \mathrm{wt} \%)$ and $\mathrm{MgO}(6.8-8.96 \mathrm{wt} \%)$. This suggests two different compositional trends in the Kushaka and Birnin Gwari granitoids and associated volcanic rocks (Fig. 9). The major element composition of the diorite, granodiorites, granites, and syenites and as well as granite gneiss plotted on Harker diagram using $\mathrm{SiO}_{2}$ as an index of differentiation (Fig. 5) show that $\mathrm{TiO}_{2}, \mathrm{Fe}_{2} \mathrm{O}_{3}, \mathrm{MgO}_{2} \mathrm{CaO}$ and $\mathrm{P}_{2} \mathrm{O}_{5}$ are all negatively correlated with $\mathrm{SiO}_{2}$, and generally form a well-defined linear trend. $\mathrm{K}_{2} \mathrm{O}, \mathrm{Na}_{2} \mathrm{O}$ and $\mathrm{Al}_{2} \mathrm{O}_{3}$ also show negative correlation but with slightly scattered trend. $\mathrm{Al}_{2} \mathrm{O}_{3}$ content on the average is high in granitoids and basalts (13.5 - $\left.16.32 \mathrm{wt} \%\right)$, meaning plagioclase, hornblende and biotite are enriched in the presence of $\mathrm{Al}_{2} \mathrm{O}_{3} . \mathrm{Na}_{2} \mathrm{O}$ values are low in the basalt and diorite (1.40 $1.67 \mathrm{wt} \%)$ but high in granodiorite, tonalite, granite, syenite and granite gneiss $(2.42-5.42 \mathrm{wt} \%)$. The content of $\mathrm{K}_{2} \mathrm{O}$ is very low in basalt $(0.19-0.34 \mathrm{wt} \%)$, very high in syenite $(5.98-6.37 \mathrm{wt} \%)$, high in granite, diorite and tonalite $(3.71-4.76 \mathrm{wt} \%)$, and relatively low in granodiorite $(1.6-2.97 \mathrm{wt} \%)$. Basalt, tonalite, granite and granodiorite are generally sub-potassic with $\mathrm{K}_{2} 0 / \mathrm{Na}_{2} 0<1$; while diorite, syenite, quartzolite and a sample each of granite leucosome (KGR22) and migmatite gneiss ( $\left.\mathrm{KGN}_{27}\right)$ with $\mathrm{K}_{2} 0 / \mathrm{Na}_{2} \mathrm{O}>1$ are slightly potassic (Table 2). $\mathrm{P}_{2} \mathrm{O}_{5}$ content is low in basalt $(0.05-0.17 \mathrm{wt} \%)$, vary in granodiorite $(0.21-0.35 \mathrm{wt} \%)$ and granite $(0.04-$ $0.51 \mathrm{wt} \%)$, but relatively high in syenite $(0.35-0.44 \mathrm{wt} \%)$, this probably explains lack of apatite crystals in the granite and granodiorite compared to the syenite $(0.35-0.44 \mathrm{wt} \%)$ with apatite in the accessory phase. $\mathrm{TiO}_{2}$ is high in basalt and diorite $(0.7-1.89$ wt $\%)$ and decrease gradually from tonalite and granodiorite $(0.56-1.3 \mathrm{wt} \%)$ to syenite $(0.50-0.57 \mathrm{wt} \%)$ and granite and granite gneiss $(0.13-$ $0.45 \mathrm{wt} \%$ ). High $\mathrm{TiO}_{2}$ contents in basalt, diorite, tonalite granodiorite and syenite are consistent with higher modal contents of biotite, hornblende and iron-oxide (magnetite and ilmenite). Lower $\mathrm{TiO}_{2}$ content in the granite and is probably as a result of fractionation of biotite and iron-rich minerals. 
Table 2: Major (Wt \%) Abundance in the Granitoids and Associated Volcanic Rocks in the Northern Part of the Kushaka and the Birnin Gwari Schist Belts

\begin{tabular}{|c|c|c|c|c|c|c|c|c|c|c|c|c|c|c|c|}
\hline $\begin{array}{l}\text { Sampl } \\
\text { e }\end{array}$ & KB1 & KB2 & KD3 & KTN4 & $\begin{array}{l}\text { KGD } \\
5\end{array}$ & $\begin{array}{l}\text { KGD } \\
6\end{array}$ & $\begin{array}{l}\text { KGD } \\
7\end{array}$ & $\begin{array}{l}\text { KGD } \\
8\end{array}$ & $\begin{array}{l}\text { KGD } \\
9\end{array}$ & $\begin{array}{l}\text { KSy1 } \\
0\end{array}$ & $\begin{array}{l}\text { KSy1 } \\
1\end{array}$ & $\begin{array}{l}\text { KKG1 } \\
2\end{array}$ & $\begin{array}{l}\text { KKG1 } \\
3\end{array}$ & $\begin{array}{l}\text { KKG1 } \\
4\end{array}$ & $\begin{array}{l}\text { KKG1 } \\
5\end{array}$ \\
\hline & \multicolumn{2}{|c|}{$\begin{array}{l}\text { KGC } \\
\text { Volcanic }\end{array}$} & \multicolumn{7}{|c|}{ Basement Complex Granitoids (BCG) } & \multicolumn{6}{|c|}{ Kushaka Granite } \\
\hline$(\%)$ & \multicolumn{2}{|c|}{ Basalt } & $\begin{array}{l}\text { Diorit } \\
\mathrm{e}\end{array}$ & $\begin{array}{l}\text { Tonalit } \\
\mathrm{e}\end{array}$ & \multicolumn{5}{|c|}{ Granodiorite/Paleosome } & \multicolumn{2}{|l|}{ Syenite } & \\
\hline $\mathrm{SiO}_{2}$ & 49.56 & $\begin{array}{l}49.7 \\
2\end{array}$ & 60.77 & 64.45 & 67.98 & 63 & 67.11 & 66.81 & 65.24 & 65.87 & 64.02 & 74.28 & 69.78 & 71.12 & 70.79 \\
\hline $\mathrm{TiO}_{2}$ & 0.7 & 1.89 & 0.93 & 0.6 & 0.56 & 0.84 & 1.3 & 0.65 & 0.82 & 0.5 & 0.57 & 0.13 & 0.18 & 0.18 & 0.25 \\
\hline $\mathrm{Al}_{2} \mathrm{O}_{3}$ & 14.74 & $\begin{array}{l}13.7 \\
3\end{array}$ & 13.5 & 15.55 & 15.54 & 15.34 & 12.87 & 14.33 & 15.99 & 14.07 & 13.22 & 15.32 & 16.32 & 15.03 & 15.74 \\
\hline $\mathrm{Fe}_{2} \mathrm{O}_{3}$ & 10.14 & $\begin{array}{l}13.5 \\
2\end{array}$ & 7.04 & 4.78 & 4.03 & 5.67 & 7.69 & 7.15 & 5.13 & 4.07 & 4.54 & 0.83 & 1.57 & 1.27 & 2.17 \\
\hline $\mathrm{MnO}$ & 0.16 & 0.21 & 0.12 & 0.11 & 0.04 & 0.11 & 0.17 & 0.18 & 0.07 & 0.07 & 0.09 & 0.01 & 0.02 & 0.03 & 0.04 \\
\hline $\mathrm{MgO}$ & 8.96 & 6.8 & 4.2 & 2.07 & 1.36 & 2.53 & 1.71 & 1.11 & 2.31 & 2.06 & 2.68 & 0.26 & 0.21 & 0.45 & 0.38 \\
\hline $\mathrm{CaO}$ & 12.65 & $\begin{array}{l}11.7 \\
5\end{array}$ & 5.2 & 3.71 & 4.22 & 4.93 & 2.62 & 4.38 & 3.06 & 2.23 & 2.86 & 1.28 & 1.16 & 1.57 & 1.35 \\
\hline $\mathrm{Na}_{2} \mathrm{O}$ & 1.4 & 1.41 & 1.67 & 4.12 & 3.83 & 3.03 & 2.42 & 2.73 & 3.87 & 4.32 & 4.08 & 4.76 & 5.98 & 4.86 & 5.42 \\
\hline $\mathrm{K}_{2} \mathrm{O}$ & 0.19 & 0.34 & 4.18 & 3.09 & 1.64 & 2.97 & 2.66 & 2.23 & 1.6 & 5.98 & 6.37 & 3.71 & 4.2 & 4.16 & 3.98 \\
\hline $\mathrm{P}_{2} \mathrm{O}_{5}$ & 0.05 & 0.17 & 0.43 & 0.25 & 0.21 & 0.34 & 0.21 & 0.15 & 0.35 & 0.35 & 0.44 & 0.04 & 0.07 & 0.06 & 0.1 \\
\hline LOI & 0.34 & 0.61 & 0.66 & 0.39 & 0.69 & 0.92 & 0.48 & 0.26 & 1.09 & 0.18 & 0.37 & 0.47 & 0.78 & 0.2 & 0.46 \\
\hline Total & $\begin{array}{l}100.1 \\
5\end{array}$ & $\begin{array}{l}98.8 \\
9\end{array}$ & 98.7 & 99.12 & 100.1 & 99.68 & 99.24 & 99.98 & 99.53 & 99.7 & 99.24 & 101.09 & 100.27 & 98.93 & 100.68 \\
\hline $\begin{array}{l}\mathrm{K}_{2} \mathrm{O} / \\
\mathrm{Na}_{2} \mathrm{O} \\
\end{array}$ & 0.13 & 0.24 & 2.50 & 0.75 & 0.42 & 0.98 & 1.09 & 0.81 & 0.41 & 1.38 & 1.56 & 0.77 & 0.70 & 0.85 & 0.73 \\
\hline $\begin{array}{l}\text { Samp } \\
\text { le } \\
\end{array}$ & $\begin{array}{l}\text { KKG } \\
16 \\
\end{array}$ & $\begin{array}{l}\text { KBG } \\
17 \\
\end{array}$ & $\begin{array}{l}\text { KBG } \\
18 \\
\end{array}$ & $\begin{array}{l}\text { KBG } \\
19 \\
\end{array}$ & $\begin{array}{l}\text { KBG } \\
20 \\
\end{array}$ & $\begin{array}{l}\text { KBG } \\
21 \\
\end{array}$ & $\begin{array}{l}\text { KGR } \\
22 \\
\end{array}$ & $\begin{array}{l}\text { KGR } \\
23 \\
\end{array}$ & $\begin{array}{l}\text { KQZL } \\
24 \\
\end{array}$ & $\begin{array}{l}\text { KGN } \\
25 \\
\end{array}$ & $\begin{array}{l}\text { KGN } \\
26 \\
\end{array}$ & $\begin{array}{l}\text { KGN } \\
27 \\
\end{array}$ & $\begin{array}{l}\text { KGN } \\
28 \\
\end{array}$ & $\begin{array}{l}\text { KGN } \\
29 \\
\end{array}$ & $\begin{array}{l}\text { KGN } \\
30 \\
\end{array}$ \\
\hline$(\%)$ & $\begin{array}{l}\text { Kushaka } \\
\text { Granite } \\
\text { Granite }\end{array}$ & & Birnin & Jwari Gra & & & Leucos & me & Q/zolit & $\begin{array}{l}\text { Basem } \\
\text { Granit }\end{array}$ & $\begin{array}{l}\text { ent and K } \\
\text { e Gneiss }\end{array}$ & ushaka $\mathrm{Gr}$ & iss Com & ex & \\
\hline $\mathrm{SiO}_{2}$ & 70.41 & 70.15 & 76.73 & 73.76 & 74.06 & 75.5 & 75.44 & 73.61 & 82.42 & 70.49 & 74.42 & 70.74 & 77.53 & 67.81 & 74.89 \\
\hline $\mathrm{TiO}_{2}$ & 0.31 & 0.41 & 0.07 & 0.04 & 0.02 & 0.15 & 0.11 & 0.62 & 0.29 & 0.45 & 0.26 & 0.6 & 0.39 & 0.31 & 0.08 \\
\hline $\mathrm{Al}_{2} \mathrm{O}_{3}$ & 14.98 & 15.12 & 14.16 & 15.3 & 14.95 & 12.86 & 12.99 & 12.9 & 14.57 & 14.21 & 13.2 & 13.68 & 12.65 & 15.34 & 15 \\
\hline $\mathrm{Fe}_{2} \mathrm{O}_{3}$ & 1.93 & 2.41 & 0.64 & 0.66 & 0.36 & 0.99 & 1.32 & 4.08 & 0.03 & 2.55 & 1.55 & 3.91 & 1.93 & 2.72 & 0.78 \\
\hline $\mathrm{MnO}$ & 0.03 & 0.04 & 0.01 & 0.03 & 0.06 & 0.08 & 0.03 & 0.08 & 0.17 & 0.09 & 0.05 & 0.04 & 0.03 & 0.03 & 0.01 \\
\hline $\mathrm{MgO}$ & 0.64 & 0.86 & 0.1 & 0.11 & 0.06 & 0.13 & 0.16 & 0.9 & 1.7 & 0.79 & 0.31 & 1.1 & 0.52 & 0.75 & 0.09 \\
\hline $\mathrm{CaO}$ & 1.9 & 1.94 & 0.87 & 0.41 & 0.45 & 0.45 & 0.82 & 2.48 & 0.04 & 2.31 & 1.24 & 1.15 & 1.5 & 2.67 & 0.95 \\
\hline $\mathrm{Na}_{2} \mathrm{O}$ & 4.42 & 3.72 & 4.02 & 4.2 & 4.7 & 4.29 & 2.54 & 3.21 & 0.28 & 3.92 & 3.71 & 2.09 & 2.63 & 4.63 & 5.15 \\
\hline $\mathrm{K}_{2} \mathrm{O}$ & 4.76 & 4.86 & 4.52 & 3.87 & 3.89 & 4.14 & 6.13 & 2.79 & 0.41 & 3.6 & 4.42 & 5.81 & 1.93 & 4.06 & 3.87 \\
\hline $\mathrm{P}_{2} \mathrm{O}_{5}$ & 0.11 & 0.12 & 0.03 & 0.42 & 0.51 & 0.02 & 0.06 & 0.13 & 0.02 & 0.11 & 0.04 & 0.14 & 0.08 & 0.17 & 0.03 \\
\hline LOI & 0.21 & 0.35 & 0.42 & 0.97 & 0.7 & 0.51 & 0.27 & 0.39 & 0.57 & 0.59 & 1.01 & 0.56 & 1.04 & 0.36 & 0.4 \\
\hline Total & 99.7 & 99.98 & $\begin{array}{l}101.5 \\
7\end{array}$ & 99.77 & 99.76 & 99.12 & 99.87 & 101.1 & 100.5 & 99.11 & $\begin{array}{l}100.2 \\
1\end{array}$ & 99.82 & $\begin{array}{l}100.2 \\
3\end{array}$ & 98.85 & $\begin{array}{l}101.2 \\
5\end{array}$ \\
\hline $\begin{array}{l}\mathrm{K}_{2} \mathrm{O} / \\
\mathrm{Na}_{2} \mathrm{O}\end{array}$ & 1.07 & 1.30 & 1.12 & 0.92 & 0.82 & 0.96 & 2.41 & 0.86 & 1.46 & 0.91 & 1.19 & 2.77 & 0.73 & 0.87 & 0.75 \\
\hline
\end{tabular}

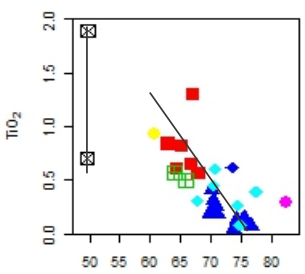

$\mathrm{SiO}_{2}$

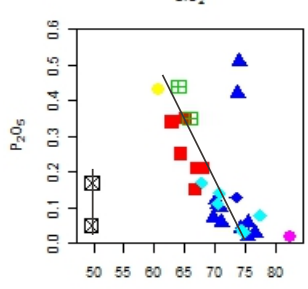

$\mathrm{SiO}_{2}$

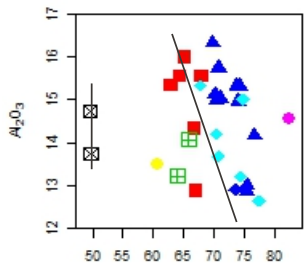

$\mathrm{SiO}_{2}$

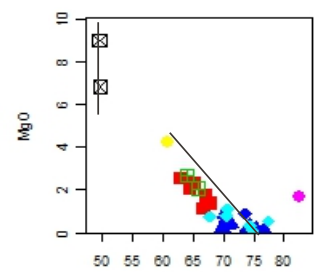

$\mathrm{SiO}_{2}$

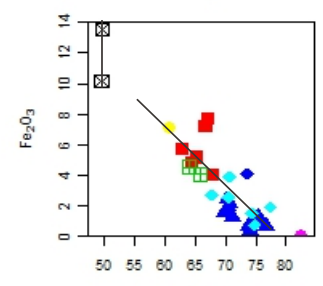

$\mathrm{SiO}_{2}$

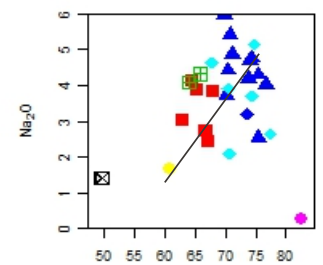

$\mathrm{SiO}_{2}$

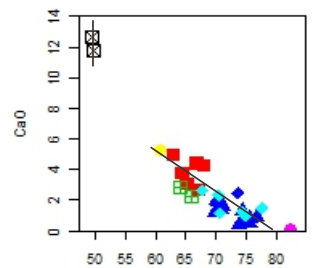

$\mathrm{SiO}_{2}$

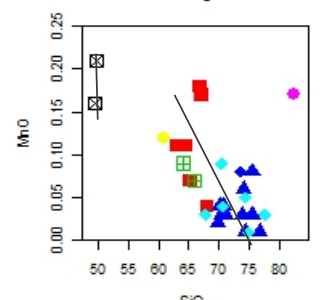

$\mathrm{SiO}_{2}$

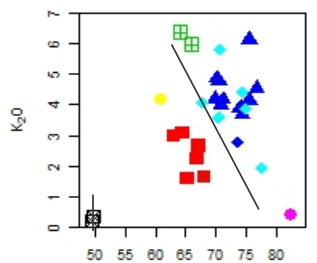

$\mathrm{SiO}_{2}$

Fig. 9: Harker Variation Diagrams; Silica ( $\mathrm{Sio}_{2} \mathrm{Wt} \%$ ) Plotted Against A Range of Major (In Wt \%) Elements in the Granitoids of the Kushaka and the Birnin Gwari Schist Belts (Symbols as in Fig. 6). 


\subsection{Trace element characteristics}

The trace elements of the granitoids plotted on Harker diagrams using $\mathrm{SiO}_{2}$ as an index of differentiation show that $\mathrm{Ba}, \mathrm{Ce}, \mathrm{Cr}, \mathrm{La}, \mathrm{Rb}$, $\mathrm{Sr}, \mathrm{Th}, \mathrm{U}, \mathrm{Zr}, \mathrm{Nb}$ and $\mathrm{Y}$ are all negatively correlated with $\mathrm{SiO}_{2}$, generally forming a well-defined linear trend; basalts however shows a trend different from the granitoids (Fig. 10). The trace elements composition and ratios are presented in Table 3 . The Sun and McDonough (1989) primitive mantle-normalized abundance patterns permit characterization of the rocks (Fig. 11). The diorite, tonalite, granodiorites, granites, syenites, and granite gneisses show similar patterns, an implication of their close genetic relationship different from basalt (Fig. 12). They generally show enrichment of the large ion lithophile elements (LILE: Ba, Rb, K; radioelements Th and U and depletion of the high field strength elements (HFSE: Nb, Ce, P and Ti), although four granite samples show depletion in Rb and Th. $\mathrm{Rb}$ is fairly enriched in the syenites $(230.8-277.8 \mathrm{ppm})$, granite $(116-164.4 \mathrm{ppm})$ and slightly depleted in granodiorite $(61.6-90.6$ $\mathrm{ppm}$ ) compared to the mean crustal average of $90 \mathrm{ppm}$. The Ba content in syenite is very high $(2644.8-2693.8 \mathrm{ppm})$, decreases in granite $(894.6$ - $1732 \mathrm{ppm})$, granite gneiss $(453.9$ - $2013.3 \mathrm{ppm})$ and granodiorites $(572.3$ - $886.2 \mathrm{ppm})$. Sr is high in granite (592.8 $1092.8 \mathrm{ppm})$, syenite $(835-857 \mathrm{ppm})$ and moderately high in granodiorite $(160.2-538.9 \mathrm{ppm})$ and granite gneiss $(143.4-1027.9 \mathrm{ppm})$ show positive correlation with increasing $\mathrm{SiO}_{2}$; consistent with relative plagioclase abundances of this rocks. $\mathrm{Th} / \mathrm{U}$ is $1.06-1.98 \mathrm{in}$ granite, 4.29 - 4.6 in syenite, 3.4 - 5.4 in granodiorite and 0.33 - 4.34 in granite gneiss.

Table 3A: Trace Elements (Ppm) Abundance in the Granitoids and Associated Volcanic Rocks in the Northern Part of the Kushaka and the Birnin Gwari Schist Belts

\begin{tabular}{|c|c|c|c|c|c|c|c|c|c|c|c|c|c|c|c|}
\hline \multirow[b]{3}{*}{$(\%)$} & KB1 & KB2 & KD3 & KTN4 & KGD5 & KGD6 & KGD7 & KGD8 & KGD9 & $\begin{array}{l}\text { KKS } \\
10 \\
\end{array}$ & $\begin{array}{l}\text { KKS } \\
11 \\
\end{array}$ & $\begin{array}{l}\text { KKG } \\
12 \\
\end{array}$ & $\begin{array}{l}\text { KKG } \\
13 \\
\end{array}$ & $\begin{array}{l}\text { KKG } \\
14 \\
\end{array}$ & $\begin{array}{l}\text { KKG } \\
15\end{array}$ \\
\hline & \multicolumn{2}{|c|}{$\begin{array}{l}\text { KGC } \\
\text { Volcanic }\end{array}$} & \multicolumn{7}{|c|}{ Basement Complex Granitoids (BCG) } & \multicolumn{6}{|c|}{ Kushaka Granite } \\
\hline & $\begin{array}{l}\text { Basa } \\
\text { lt }\end{array}$ & $\begin{array}{l}\text { Basa } \\
\text { lt }\end{array}$ & $\begin{array}{l}\text { Diori } \\
\text { te }\end{array}$ & $\begin{array}{l}\text { Tonali } \\
\text { te }\end{array}$ & $\begin{array}{l}\text { G/Dior } \\
\text { ite }\end{array}$ & $\begin{array}{l}\text { G/Dior } \\
\text { ite }\end{array}$ & $\begin{array}{l}\text { G/Dior } \\
\text { ite }\end{array}$ & $\begin{array}{l}\text { G/Dior } \\
\text { ite }\end{array}$ & $\begin{array}{l}\text { G/Dior } \\
\text { ite }\end{array}$ & $\begin{array}{l}\text { Syeni } \\
\text { te }\end{array}$ & $\begin{array}{l}\text { Syeni } \\
\text { te }\end{array}$ & $\begin{array}{l}\text { Grani } \\
\text { te }\end{array}$ & $\begin{array}{l}\text { Grani } \\
\text { te }\end{array}$ & $\begin{array}{l}\text { Grani } \\
\text { te }\end{array}$ & $\begin{array}{l}\text { Grani } \\
\text { te }\end{array}$ \\
\hline As & 3.1 & 2.9 & 0.8 & 2.4 & 4 & 0.2 & 2.4 & 3.8 & 2.8 & 1.4 & 4.7 & 0.8 & 2.1 & 0.1 & 2.2 \\
\hline $\mathrm{Ba}$ & 37 & 74.5 & $\begin{array}{l}1723 . \\
3\end{array}$ & $\begin{array}{l}1616 . \\
4\end{array}$ & 886.2 & 1247.3 & 764.7 & 572.3 & 217.5 & $\begin{array}{l}2693 . \\
8\end{array}$ & $\begin{array}{l}2644 . \\
8\end{array}$ & 894.6 & $\begin{array}{l}1600 . \\
7\end{array}$ & $\begin{array}{l}1228 . \\
9\end{array}$ & 1707 \\
\hline $\begin{array}{l}\mathrm{Ce} \\
\mathrm{Co}\end{array}$ & $\begin{array}{l}13.2 \\
82.1\end{array}$ & 27.7 & 110 & 89.3 & 104.7 & 73.4 & 145.9 & 54.4 & $\begin{array}{l}63.1 \\
40.9\end{array}$ & 121.1 & 77.3 & 10.8 & 32.9 & 34.6 & 79 \\
\hline Co & $\begin{array}{l}82.1 \\
490\end{array}$ & 79 & 51.4 & 66.4 & 72.3 & 41.9 & 54.6 & 51.3 & 40.9 & 44.2 & 51.2 & 64.2 & 52.2 & 48.9 & 42.4 \\
\hline $\mathrm{Cr}$ & $\begin{array}{l}490 . \\
1\end{array}$ & 121 & 132.3 & 50.3 & 14.1 & 43.6 & 38.7 & 22.3 & 89.2 & 68.8 & 84.5 & 26.5 & 11.3 & 25.4 & 13.7 \\
\hline $\mathrm{Cu}$ & 26.6 & 91.9 & 19.2 & 15.8 & 11.8 & 17.6 & 27.3 & 17.3 & 27.7 & 9.2 & 24.2 & 4.6 & 7.2 & 7.9 & 7.1 \\
\hline $\mathrm{Ga}$ & 13.1 & 18.6 & 18.4 & 20.4 & 16.3 & 19.1 & 19.5 & 17.3 & 17.5 & 20.2 & 19.7 & 21.6 & 22.1 & 20.6 & 20.7 \\
\hline $\mathrm{La}$ & 1.4 & 13.3 & 67.1 & 43.4 & 69 & 49.4 & 105.9 & 16.1 & 31.9 & 88.2 & 52.8 & 5.2 & 16.1 & 21.3 & 46.9 \\
\hline Мo & 0.7 & 0.8 & 0.1 & 0.1 & $<1$ & $<1$ & 2.2 & 0.3 & 0.3 & 0.1 & 2 & 0 & $<1$ & $<1$ & $<1$ \\
\hline $\mathrm{Nb}$ & 1.6 & 8.4 & 17.4 & 8.7 & 4.2 & 15.1 & 26.3 & 11 & 10.4 & 23.8 & 25.5 & 2.5 & 14.9 & 9.1 & 20.3 \\
\hline $\mathrm{Nd}$ & 0.6 & 21.7 & 50.4 & 25.7 & 35.7 & 32 & 103.6 & 28.6 & 31.9 & 48.9 & 36.3 & 1.2 & 9.8 & 14.5 & 23.6 \\
\hline $\mathrm{Ni}$ & $\begin{array}{l}135 . \\
8\end{array}$ & 51.9 & 59.3 & 15.9 & 4.2 & 6.7 & 14.3 & 5.6 & 29 & 27.9 & 35.2 & 1 & 0.5 & 3.7 & 2.7 \\
\hline $\mathrm{Pb}$ & 6.7 & 4.7 & 44.6 & 33.5 & 11.9 & 29.4 & 18.3 & 14.9 & 25.3 & 71.3 & 51.5 & 39.3 & 33 & 66.5 & 32.8 \\
\hline $\mathrm{Rb}$ & 2.8 & 4.4 & 198.4 & 89 & 61.6 & 146.8 & 151.4 & 90.6 & 63.7 & 230.8 & 277.8 & 124.7 & 103.8 & 164.4 & 116 \\
\hline $\mathrm{Sc}$ & 25.3 & 32.9 & 11.6 & 7.8 & $<1$ & 5.5 & 17.7 & 12.3 & 14.6 & 5.4 & 4.5 & 1.2 & 0.4 & 1 & 3.7 \\
\hline $\mathrm{Sn}$ & 0.4 & 1.4 & 8.4 & 7.8 & 4.7 & 8.2 & 8.1 & 3.8 & 3.8 & 8.4 & 9.6 & 6.9 & 7.6 & 6.6 & 8.3 \\
\hline $\mathrm{Sr}$ & $\begin{array}{l}102 . \\
7\end{array}$ & $\begin{array}{l}186 . \\
3\end{array}$ & 763.7 & 990.5 & 538.9 & 597.9 & 133.6 & 160.2 & 324.9 & 857.4 & 835 & 592.7 & $\begin{array}{l}1012 . \\
8\end{array}$ & 917.8 & $\begin{array}{l}1298 . \\
4\end{array}$ \\
\hline $\mathrm{Ta}$ & $<1$ & 0.3 & $<1$ & $<1$ & $<1$ & $<1$ & $<1$ & $<1$ & $<1$ & 1.7 & 1.6 & $<1$ & 0.9 & 0.5 & 0 \\
\hline Th & 0.5 & 1.9 & 20.6 & 10.4 & 11.9 & 14.1 & 15.6 & 7.5 & 6.6 & 31 & 29.2 & 2.7 & 6.3 & 8.7 & 12.7 \\
\hline $\mathrm{U}$ & 0.4 & 0.9 & 8.7 & 5.5 & 2.2 & 4.9 & 3.2 & 2.2 & 2.3 & 6.6 & 6.8 & 2.4 & 5.9 & 5.6 & 8.8 \\
\hline V & $\begin{array}{l}266 . \\
4\end{array}$ & $\begin{array}{l}384 . \\
8\end{array}$ & 160.8 & 86.1 & 78.3 & 118.8 & 113.2 & 60 & 114.2 & 50.6 & 61.7 & 11.7 & 11.4 & 16 & 17.9 \\
\hline W & $\begin{array}{l}209 . \\
2\end{array}$ & $\begin{array}{l}164 . \\
7\end{array}$ & 177.7 & 292.6 & 374.8 & 156.5 & 246.6 & 256.2 & 172.5 & 191.8 & 181.7 & 356.5 & 265.4 & 245.8 & 234.1 \\
\hline Y & 14.4 & 32.4 & 27.5 & 14.9 & 6 & 25.9 & 93.1 & 27.4 & 45.3 & 21.7 & 21 & 3.8 & 9.6 & 6.6 & 16.4 \\
\hline $\mathrm{Zn}$ & 64.4 & $\begin{array}{l}103 . \\
7\end{array}$ & 87 & 76.9 & 51.7 & 87.2 & 88.3 & 75 & 65.8 & 69.5 & 73.7 & 53.4 & 57.8 & 40.6 & 67.8 \\
\hline $\mathrm{Zr}$ & 36.6 & $\begin{array}{l}129 . \\
2\end{array}$ & 204.6 & 169.4 & 197 & 221.6 & 318.4 & 226.4 & 160.9 & 383 & 282.5 & 49.3 & 154.5 & 109.2 & 219.5 \\
\hline $\mathrm{Rb} / \mathrm{Sr}$ & 0.02 & 0.02 & 0.25 & 0.08 & 0.11 & 0.24 & 1.13 & 0.56 & 0.19 & 0.26 & 0.33 & 0.21 & 0.10 & 0.17 & 0.08 \\
\hline $\mathrm{Th} / \mathrm{U}$ & 1.25 & 2.11 & 2.36 & 1.89 & 5.40 & 2.87 & 4.8 & 3.40 & 2.86 & 4.69 & 4.29 & 1.12 & 1.06 & 1.55 & 1.44 \\
\hline
\end{tabular}

Table 3B: Trace Elements (Ppm) Abundance in the Granitoids and Associated Volcanic Rocks in the Northern Part of the Kushaka and the Birnin Gwari Schist Belts

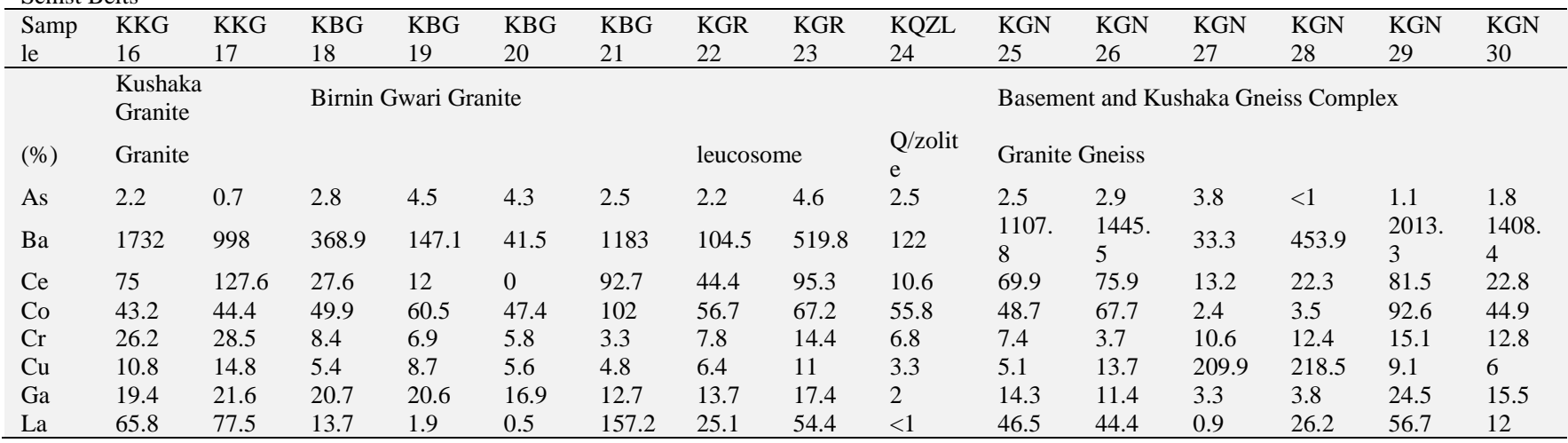




\begin{tabular}{|c|c|c|c|c|c|c|c|c|c|c|c|c|c|c|c|}
\hline Mo & $<1$ & 0 & $<1$ & 0.3 & 0 & 0.5 & 0.1 & 0.3 & $<1$ & 0.1 & 0.3 & $<1$ & $<1$ & $<1$ & $<1$ \\
\hline $\mathrm{Nb}$ & 8.1 & 16.6 & 10.6 & 30.5 & 17.7 & 9.2 & 7.3 & 18.3 & 6.6 & 7.8 & 10.3 & $<1$ & $<1$ & 12 & 6 \\
\hline $\mathrm{Nd}$ & 26.9 & 40.8 & 11.6 & 6 & 0.8 & 88.7 & 19.4 & 43.7 & 6.5 & 31.1 & 23.8 & 10.5 & 5.5 & 41.6 & 16.3 \\
\hline $\mathrm{Ni}$ & 6.2 & 8.3 & 0.9 & 1.5 & 0.9 & 1.4 & 2 & 5 & $<1$ & 0.9 & 1.2 & 1.8 & 4 & 2.2 & 1.5 \\
\hline $\mathrm{Pb}$ & 33.8 & 33.4 & 55.9 & 13.2 & 15.7 & 24.1 & 33.9 & 17.6 & 0.6 & 41 & 41.1 & 35.3 & 25.6 & 41 & 70.3 \\
\hline $\mathrm{Rb}$ & 130.3 & 215.5 & 180.1 & 387.5 & 363 & 156.1 & 430.1 & 132.8 & 6.5 & 102.6 & 140.9 & 13.6 & 12 & 85 & 97.7 \\
\hline $\mathrm{Sc}$ & $<1$ & 5.1 & 2.8 & 1.7 & $<1$ & 3.7 & 4.7 & 6.6 & 1.8 & 7.4 & 1 & $<1$ & $<1$ & 2 & 0.8 \\
\hline $\mathrm{Sn}$ & 6.5 & 7.8 & 5.3 & 14.6 & 11.7 & 7.2 & 10 & 7.9 & 6.9 & 5.9 & 8.2 & 38.6 & 30.6 & 8.4 & 6.4 \\
\hline $\mathrm{Sr}$ & $\begin{array}{l}1032 . \\
3\end{array}$ & 285.3 & 133.1 & 38.5 & 26.3 & 46.1 & 33.4 & 102.8 & 8.2 & 230.7 & 143.4 & 131.2 & 290.8 & $\begin{array}{l}1027 . \\
9\end{array}$ & 631.7 \\
\hline $\mathrm{Ta}$ & 0 & 1.5 & 1 & 8.6 & 9.3 & $<1$ & $<1$ & 0.1 & $<1$ & $<1$ & $<1$ & $<1$ & $<1$ & 0.5 & $<1$ \\
\hline Th & 11.7 & 17.1 & 8.6 & 1 & 0.4 & 20.6 & 19.9 & 16.6 & 1.2 & 14.8 & 21.7 & $<1$ & $<1$ & 13.2 & 3 \\
\hline $\mathrm{U}$ & 5.9 & 3.4 & 5.9 & 9.5 & 15.7 & 6.5 & 14.2 & 2.5 & 0.1 & 3.7 & 5 & 0.9 & 2.7 & 6.1 & 3.2 \\
\hline V & 24.5 & 38.8 & 6.4 & 1.1 & $<1$ & 3.8 & 6.7 & 37.5 & 6.2 & 20.7 & 10.1 & 2.6 & 4 & 31.4 & 8.8 \\
\hline W & 204.7 & 252.9 & 293.8 & 337.3 & 349 & 570.4 & 394.8 & 361 & 341.8 & 254.8 & 367.4 & $<1$ & 2.3 & 195 & 275.5 \\
\hline $\mathrm{Y}$ & 10.3 & 27.4 & 9.4 & 6.1 & 4.5 & 60.5 & 41.9 & 51.2 & 13.9 & 31.6 & 21.5 & 3.6 & 2.9 & 7.9 & 10.5 \\
\hline $\mathrm{Zn}$ & 46.8 & 45.9 & 16.1 & 38.6 & 21.8 & 21.4 & 18.8 & 36.9 & 0.5 & 54 & 29.6 & 43.3 & 685.6 & 133.4 & 23.7 \\
\hline $\mathrm{Zr}$ & 157.3 & 150.6 & 64 & 30 & 22.4 & 144.1 & 57.3 & 227.5 & 135.3 & 166.4 & 175.4 & 28.2 & 20 & 240.6 & 59.6 \\
\hline $\mathrm{Rb} / \mathrm{Sr}$ & 0.12 & 0.75 & 1.35 & 10.06 & 13.80 & 3.38 & 12.87 & 1.29 & 0.79 & 0.44 & 0.98 & 0.10 & 0.04 & 0.08 & 0.15 \\
\hline $\mathrm{Th} / \mathrm{U}$ & 1.98 & 5.02 & 1.45 & 0.10 & 0.02 & 3.16 & 1.40 & 6.64 & 12.0 & 4.0 & 4.34 & 1.0 & 0.33 & 2.16 & 0.93 \\
\hline
\end{tabular}

Basalt: KB1=Marinai, KB2=Kabugu. Diorite: KD3=Kwona Mutua. Tonalite: KTN4=Sabo-Layi, Granodiorite: KGD5=Marinai KGD6=Gwaska paleosome, KGD7=Ungwan Madaki, KGD8=Sabon Kushaka, KGD9=BirninGwari / Mando. Syenite: KSy10=Koriga, KSy11=Koriga. Granite (Kushaka): KKG12=Maganda (Por), KKG13=Maganda, KKG14=Udawa, KKG15=Kugu, KKG16=Manini. Granite (Birnin Gwari): KBG17=Goron Dutse (Por), KBG18=Goron Dutse, KBG19=Mando, KBG20=Mando/Loko, KBG21=Nasarawa Kwona, KGR22=Gwaska (Por leucosome), KGR23=Ungwan Madaki Leucosome. Quartzolite: KQZL24=Quarzolite Granite Gneiss: KGN25= Kampani Doka, KGN26= Kampani Doka, KGN27=Kungwi Granite, KGN28=Kugu, KGN29= Gwagwaulu, KGN3= Gwagwaulu.

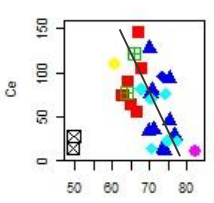

$\mathrm{SiO}_{2}$

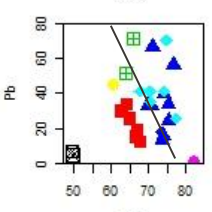

$\mathrm{SiO}_{2}$

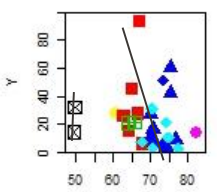

so

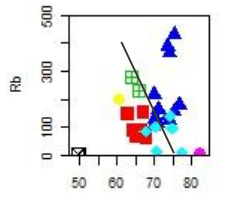

$\mathrm{SiO}_{2}$

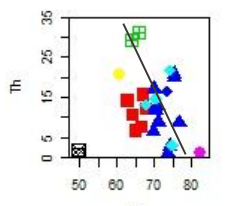

$\mathrm{SiO}_{2}$

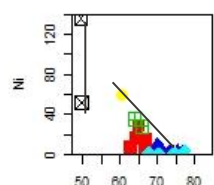

so

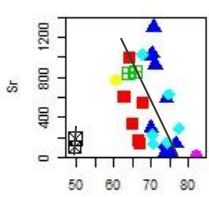

$\mathrm{SiO}_{2}$
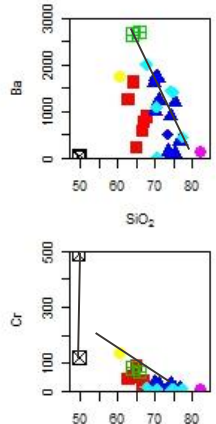
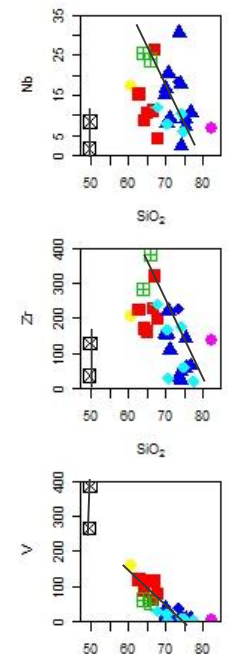

Fig. 10: Harker Variation Diagrams; Silica ( $\mathrm{Sio}_{2}$ Wt \%) Plotted Against A Range of Trace (In Ppm) Elements in the Granitoids and Associated Basalt of the Kushaka and the Birnin Gwari Schist Belts (Symbols as in Fig. 6).

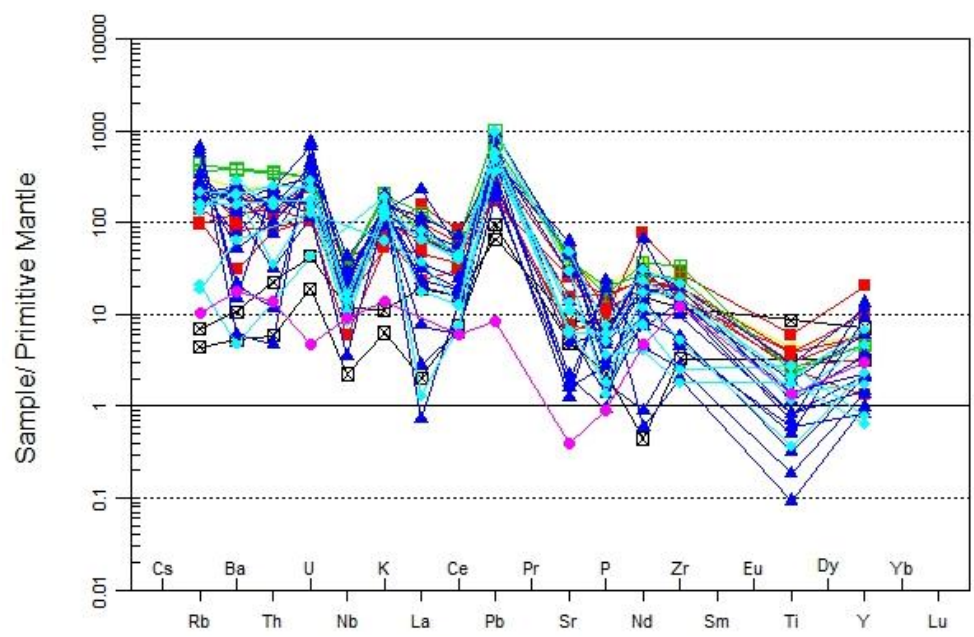

Fig. 11: Mantle-Normalized Multi-Element Diagram of Granitoid in the Northern Part of the Kushaka and the Birnin Gwari Schist Belts (Sun and Mcdonough, 1989) (Symbols as in Fig. 6). 


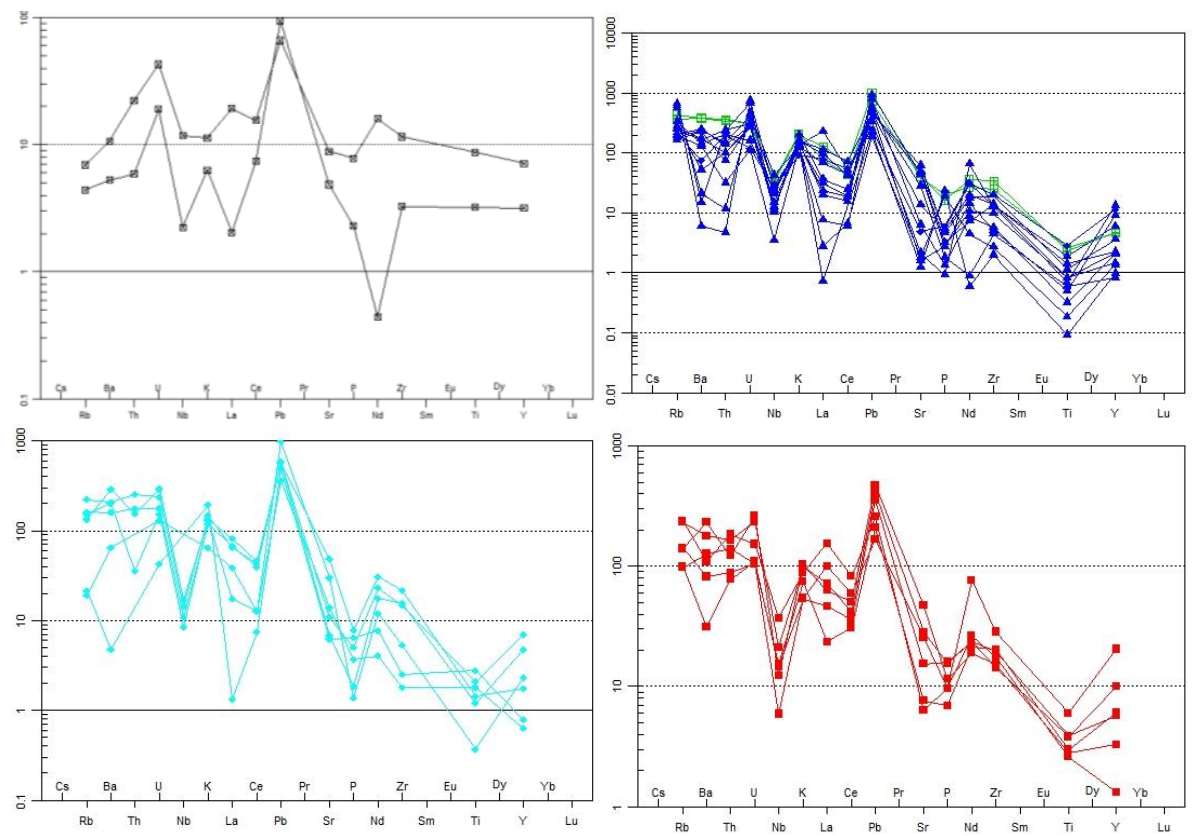

Fig. 12: Mantle-Normalized Multi-Element Diagram of Each Rock Type Showing (A): Basalt=Black (B): Granite =Blue (C): Granitoid Gneiss=Till and (D): Granodiorites=Red in the Kushaka and the Birnin Gwari Schist Belts (Sun and Mcdonough, 1989) (Symbols as in Fig. 6).

\subsection{Rare earth elements distribution characteristics}

The REE data and chondrite-normalized distribution patterns are presented in Table 4 and Fig. 13 respectively. The normalization values are those of Boynton (1984). The total sum of REEs ( $\sum$ REE) in the Basement granitoids ranges from $21.42-382.40$ while in the Kushaka granite and Birnin Gwari granite it ranges from $18.90-227.51$ and $15.90-240.56$. The different rock types exhibit similar REE distribution pattern. The granitoids exhibit light rare earth elements (LREE) enrichment relative to the heavy rare earth elements (HREE) and thus a high degree of fractionation of the LREE relative to HREE. The values of (La/Yb)N increase from 1.05 in granite gneiss to 77.20 in the granodiorites. The rocks also show moderate negative Eu anomaly with Eu/Eu* values between $0.66-0.79$. Syenites however exhibit near flat HREE distribution pattern with near absence of Eu anomaly. Basalts exhibits pattern of MORB and back arc provenience (Fig. 13) with total REE concentrations of $\left(\sum \mathrm{REE}=4.96\right)$, flat LREE and HREE trend, no Eu anomaly, and low fractionation $[(\mathrm{La} / \mathrm{Yb}) \mathrm{N}=1.40]$. Diorite, tonalite and granodiorite show high degree of fractionation $[(\mathrm{La} / \mathrm{Yb}) \mathrm{N}=13.72-77.20]$ as well as the Kushaka granite $[(\mathrm{La} / \mathrm{Yb}) \mathrm{N}=43.82-44.67]$ and the Birnin Gwari granite $[(\mathrm{La} / \mathrm{Yb}) \mathrm{N}=6.74-45.14]$.

Table 4: REE Data (Ppm) on the Granitoids in the Northern Part of the Kushaka and the Birnin Gwari Schist Belts

\begin{tabular}{|c|c|c|c|c|c|c|c|c|c|c|}
\hline Sample & KB1 & KD3 & KTN4 & KGD7 & KSy10 & KKG17 & KBG19 & KBG19 & KGR23 & KGN28 \\
\hline $\mathrm{La}$ & 0.5 & 45.8 & 26.3 & 80.8 & 58.3 & 3.9 & 61.6 & 2.9 & 39.8 & 3.0 \\
\hline $\mathrm{Ce}$ & 1.16 & 91.05 & 56.72 & 123.11 & 99.37 & 7.58 & 111.15 & 5.87 & 82.16 & 6.79 \\
\hline $\operatorname{Pr}$ & 0.2 & 11.06 & 5.26 & 21.01 & 11.87 & 1.07 & 12.17 & 0.79 & 10.51 & 0.98 \\
\hline $\mathrm{Sm}$ & 0.32 & 6.22 & 2.04 & 18.62 & 6.04 & 0.91 & 5.83 & 0.78 & 8.11 & 1.03 \\
\hline $\mathrm{Eu}$ & 0.13 & 1.12 & 0.42 & 2.86 & 1.36 & 0.09 & 0.64 & 0.16 & 0.96 & 0.24 \\
\hline Gd & 0.41 & 4.06 & 1.53 & 20.20 & 4.58 & 0.71 & 4.49 & 0.80 & 7.80 & 1.20 \\
\hline $\mathrm{Tb}$ & 0.07 & 0.39 & 0.15 & 3.02 & 0.50 & 0.08 & 0.54 & 0.14 & 1.16 & 0.20 \\
\hline Dy & 0.49 & 1.56 & 0.70 & 16.90 & 2.40 & 0.33 & 2.79 & 0.82 & 6.56 & 1.23 \\
\hline Ho & 0.1 & 0.24 & 0.12 & 2.83 & 0.42 & 0.05 & 0.49 & 0.13 & 1.13 & 0.20 \\
\hline Er & 0.27 & 0.57 & 0.33 & 6.37 & 1.11 & 0.10 & 1.25 & 0.33 & 2.64 & 0.44 \\
\hline $\mathrm{Tm}$ & 0.04 & 0.07 & 0.05 & 0.76 & 0.15 & 0.01 & 0.17 & 0.05 & 0.32 & 0.05 \\
\hline $\mathrm{Yb}$ & 0.24 & 0.40 & 0.27 & 3.97 & 0.88 & 0.06 & 0.92 & 0.29 & 1.66 & 1.93 \\
\hline $\mathrm{Lu}$ & 0.03 & 0.06 & 0.04 & 0.55 & 0.13 & $<0.01$ & 0.12 & 0.04 & 0.23 & 0.03 \\
\hline$\sum \mathrm{REE}$ & 4.96 & $202 . .3$ & 110.73 & 382.40 & 227.51 & 18.90 & 240.56 & 15.90 & 201.74 & 21.42 \\
\hline$(\mathrm{La} / \mathrm{Yb})_{\mathrm{N}}$ & 1.40 & 77.20 & 65.67 & 13.72 & 44.67 & 43.82 & 45.14 & 6.74 & 16.16 & 1.05 \\
\hline$(\mathrm{Ce} / \mathrm{Yb})_{\mathrm{N}}$ & 1.25 & 58.88 & 54.34 & 8.02 & 29.21 & 32.68 & 31.25 & 5.24 & 12.80 & 0.91 \\
\hline$(\mathrm{Ce} / \mathrm{Sm})_{\mathrm{N}}$ & 0.87 & 3.53 & 6.71 & 1.60 & 3.97 & 2.01 & 4.60 & 1.82 & 2.44 & 1.59 \\
\hline$(\mathrm{Eu} / \mathrm{Yb})_{\mathrm{N}}$ & 1.54 & 7.96 & 4.42 & 2.05 & 439 & 4.27 & 1.98 & 1.57 & 1.64 & 0.35 \\
\hline $\mathrm{Eu} / \mathrm{Eu}^{*}$ & 1.10 & 0.68 & 0.73 & 0.45 & 0.79 & 0.34 & 0.38 & 0.62 & 0.37 & 0.66 \\
\hline
\end{tabular}

\subsection{Magma characterization}

The magma types are illustrated by AFM diagram of Irvine and Baragar (1971) and the $\mathrm{Fe}_{2} \mathrm{O}_{3} / \mathrm{MgO}$ ratios against $\mathrm{SiO}_{2}$ contents of Miyashiro (1974) and which shows tholeiite and calc-alkaline affinity. Basalt and granodiorite (paleosome samples KGD6 \&KGD7) and granite (leucosome samples KGR22 \& KGR23) has tholeiitic affinity while granite, syenite, granodiorite quartzolite and granite gneiss cluster in the calc-alkaline field (Fig. $14 \mathrm{~A}$ and B). The $\mathrm{SiO}_{2}$ vs $\mathrm{Fe}_{2} \mathrm{O}_{3} /\left(\mathrm{Fe}_{2} \mathrm{O}_{3}+\mathrm{MgO}\right.$ ); $\mathrm{SiO}_{2}$ vs $\mathrm{Na}_{2} \mathrm{O}+\mathrm{K}_{2} \mathrm{O}-\mathrm{CaO}$ and ASI vs A/NK diagram (after Frost et al, 2001) distinguished the granitoids as ferroan and magnesian character, alkalic to calcic and metaluminous to peraluminous respectively (Fig. 15). The diorites and granodiorites can further be classified into calcic to calc-alkalic while granite and syenite are alkalic to alkali-calcic on the on the Modified Alkali-Lime Index (MALI) plot of $\mathrm{Na}_{2} \mathrm{O}+\mathrm{K}_{2} \mathrm{O}-\mathrm{CaO}$ versus $\mathrm{SiO}_{2}$ discrimination diagram (Frost et al., 2001) (Fig. 15B). The granitoids are metaluminous to peraluminous with aluminium saturated index (ASI) ranging from 0.7 to 1.5 , however, syenites straddle the line between metaluminous and peralkaline (Fig. 15C). The alkali concentration 
discrimination diagram $\mathrm{K}_{2} \mathrm{O}$ vs $\mathrm{Na}_{2} \mathrm{O}$ in wt $\%$ and $\mathrm{SiO}_{2}$ vs $\mathrm{K}_{2} \mathrm{O}$ of Peccerillo and Taylor (1976) defined the basalt as tholeiitic; granitoids and granodiorites as calc-alkaline and high-K cala-alkaline; diorite and syenite as shoshonite series, and all I-type. Diorite sample in Kwona Mutua (KD3), granite gneiss samples (KGN28) in Kugu and Ungwan Madaki and Gwaska paleosome of granodioritic composition (KGD6 and KGD7) are S-type granitoids (Figs. 1 \& 16A \& B). Using the series of diagrams that employ Ga/Al and Y, Ce, $\mathrm{Nb}$ and $\mathrm{Zr}$ against various major elements ratios, Ce, $\mathrm{Y}, \mathrm{Zn}$ and $\mathrm{Zr}$ designed by Whalen et al., (1987) to discriminate A-type granites from I- and S-types (Fig. 17), granitoids plot in the field of I- and S- type or close to the boundary of the A-type granite. On Sr- Rb-Ba ternary diagram after Tarney and Jones (1994) (Fig. 18A), the granitoids shows a trend towards Ba, known as the HiBaSr trend, typical of high Ba-Sr granitoids. The Ba-Rb-Sr ternary diagram (after El Bouseily and El Sokkary, 1975) also shows wide distribution of the granites and granodiorites as granodiorite and quartz diorite, anomalous, normal"and strongly differentiated; syenite as anomalous and basalt as diorite (Fig. 18 B).

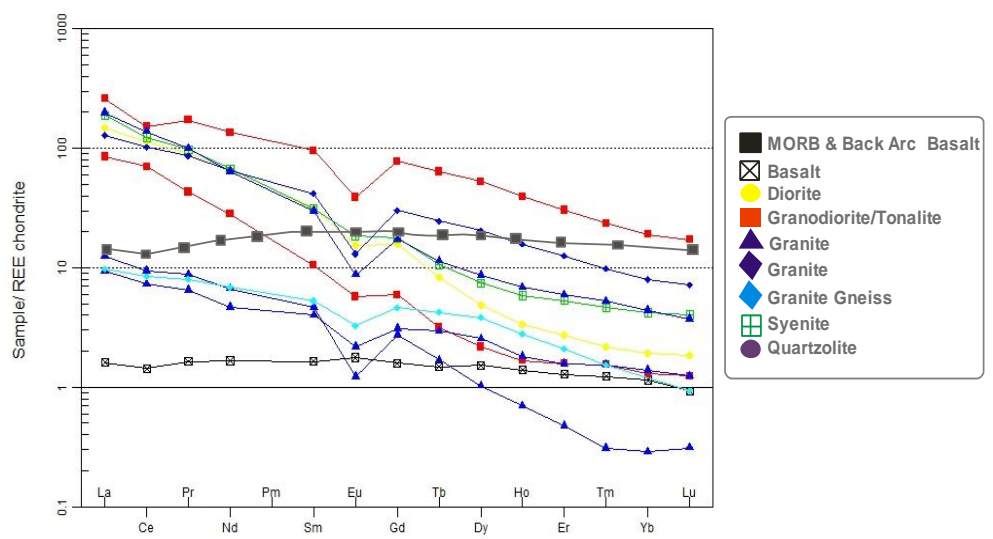

Fig. 13: Chondrite-Normalized Pattern for the Kushaka and the Birnin Gwari Schist Belts Granitoids, Chondrite Normalization Values are From (Boynton, 1984) (Symbols as in Fig. 6).
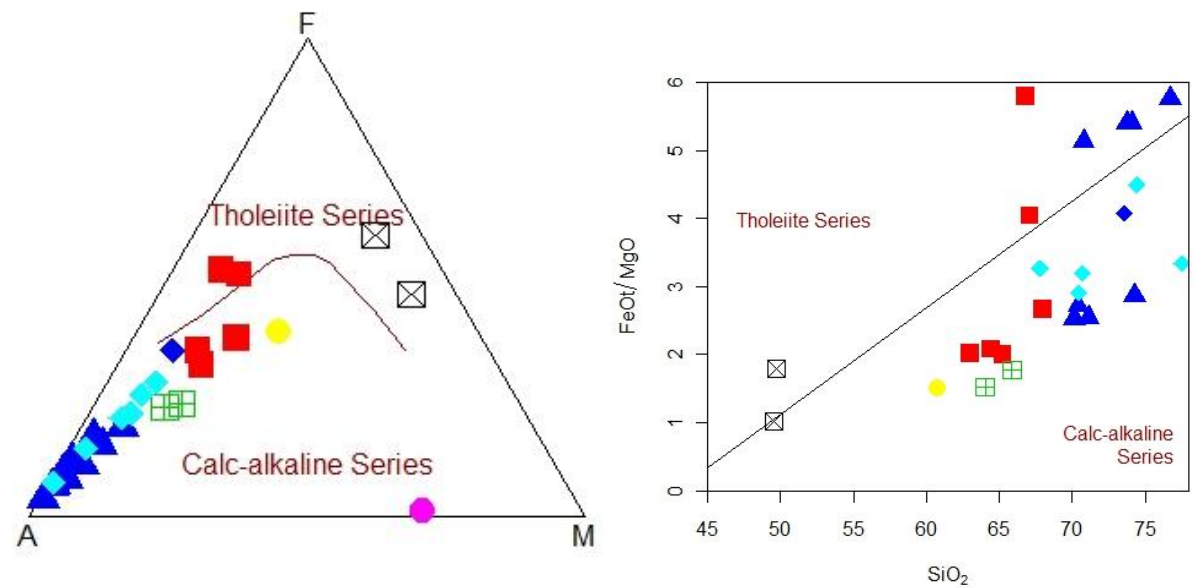

Fig. 14: (A) AFM Diagram (After Irvine and Baragar, 1971) and (B) $\mathrm{Sio}_{2} \mathrm{Vs} \mathrm{Fe}_{2} \mathrm{O}_{3}$ /Mgo Diagram (After Miyashiro, 1974) Discriminating Granitoids and Basalt As Tholeiite and Calc-Alkaline Series (Symbols as in Fig. 6).
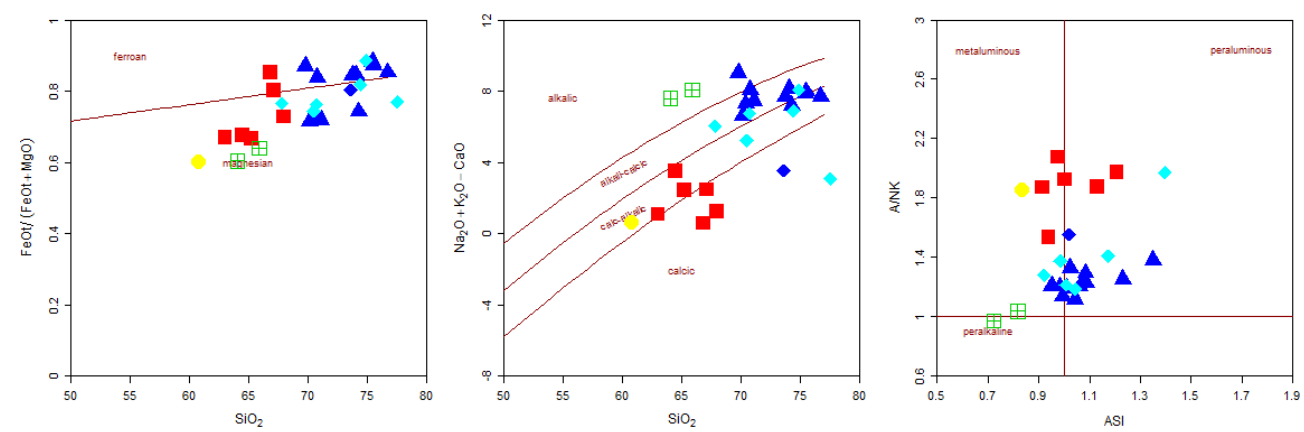

Fig. 15: (A) $\mathrm{Sio}_{2} \mathrm{Vs} \mathrm{Fe}_{2} \mathrm{O}_{3} /\left(\mathrm{Fe} 2 \mathrm{O} 3+\mathrm{Mgo}\right.$ ); (B) $\mathrm{Sio}_{2} \mathrm{Vs} \mathrm{Na}_{2} \mathrm{O}+\mathrm{K}_{2} \mathrm{O}-\mathrm{Cao}$ and (C) ASI Vs A/NK Diagram (After Frost Et Al, 2001) Discriminating Granitoids as Ferroan to Magnesian, Alkali to Calcic and Metaluminous to Peraliminous (Symbols as in Fig. 6). 

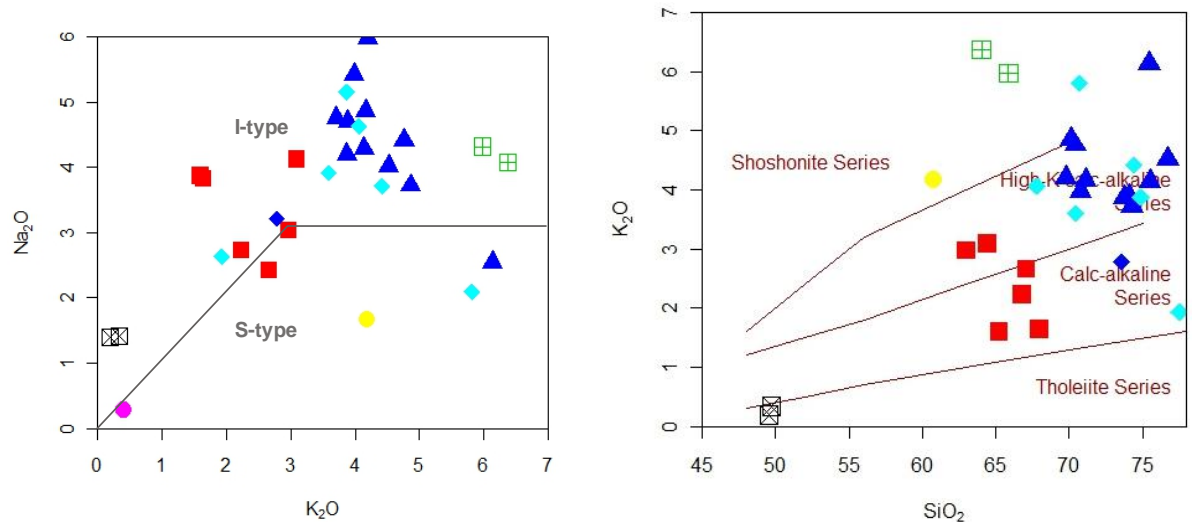

Fig. 16: (A) Alkali Concentration Discrimination Diagram $\left(\mathrm{K}_{2} \mathrm{O} \mathrm{Vs} \mathrm{Na} \mathrm{N}_{2} \mathrm{O}\right.$ in Wt $\%$ ) Defining the I- and S-Type Nature of the Granitoids and (B) Sio $\mathrm{V}_{2}$ $\mathrm{K}_{2} \mathrm{O}$ after Peccerillo and Taylor (1976) Discriminating Basalt as Tholeiite and Granitoids as Calc-Alkaline, High-K Calc-Alkaline and Shoshonite Series (Symbols as in Fig. 6).

\subsection{Provenance and geotectonic setting}

On the multicratonic R1-R2 diagram of Batchelor and Bowden (1985), the diorite plots in the pre-collision field, granodiorites plot in the pre-collision and syn-collisional fields; tonalite plots in the post collision uplift field, granites and granite gneisses plot dominantly in the syn-collisional field; syenite plots in the late-orogenic field and basalt together with some paleosome and leucosome samples plot in the mantle fractionates (Fig. 19A). This tectonic setting is also confirmed by the $\mathrm{Zr}$ vs. $\mathrm{Zr} / \mathrm{Y}$ discrimination diagram of Pearce (1983) which shows basalt, granodioritic paleosome and granitic leucosome as oceanic arc type and other granitoids as continental arc type (Fig. 19B). The $\mathrm{Y}+\mathrm{Nb}$ vs $\mathrm{Rb}$ and $\mathrm{Y}$ vs $\mathrm{Nb}$ geotectonic discrimination diagram (after Pearce et al., 1984) showed basalt and quartzolite plot in the volcanic arc field while granitoids plot in the volcanic arc and syn-collision granitoid fields (Fig. 20). $\mathrm{The}^{\mathrm{SiO}_{2}} \mathrm{vs}_{2} \mathrm{O} ; \mathrm{SiO}_{2} \mathrm{vs}$ $\mathrm{Fe}_{2} \mathrm{O}_{3} /\left(\mathrm{Fe}_{2} \mathrm{O}_{3}+\mathrm{MgO}\right), \mathrm{M} / \mathrm{AFM}$ vs F/AFM and C/ACF vs F/ACF tectonic discrimination diagram of Maniar and Piccolli, (1989), shows the granitoids plot in the fields of island arc (IAG), continental arc granite (CAG) and continental collision granite (CCG) (Fig. 21).
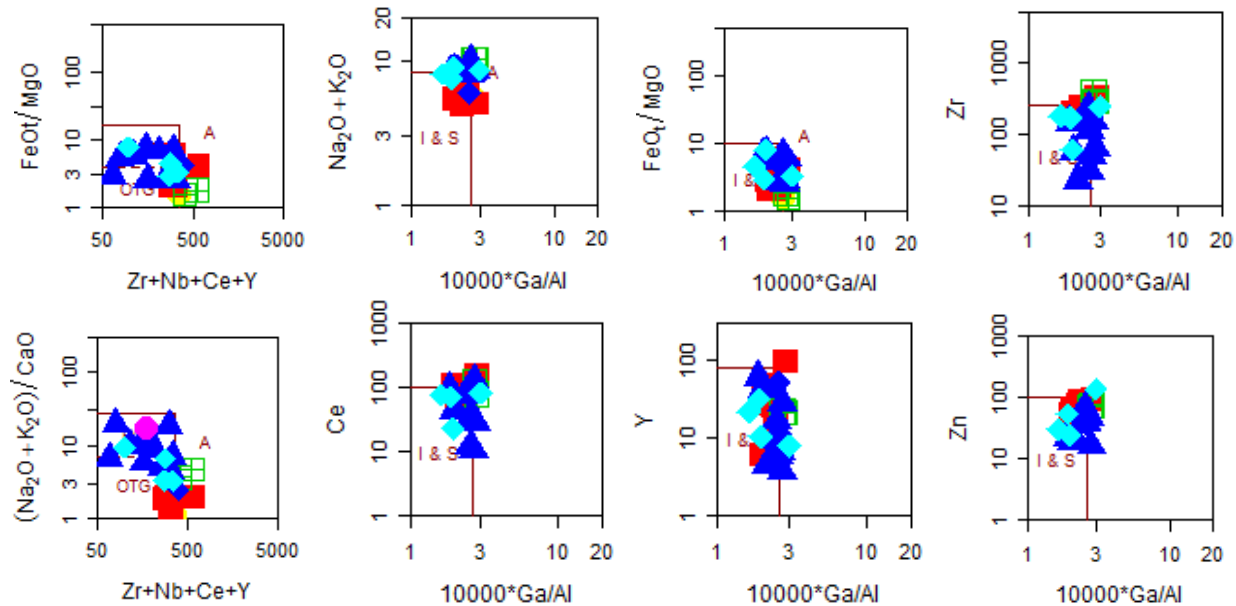

Fig. 17: Set of Binary Plots $\mathrm{Zr}+\mathrm{Nb}+\mathrm{Ce}+\mathrm{Y} \mathrm{Vs} \mathrm{Fe}_{2} \mathrm{O}_{3} / \mathrm{Mgo}$ and $\left(\mathrm{Na}_{2} \mathrm{O}+\mathrm{K}_{2} \mathrm{O}\right) / \mathrm{Cao} ; 10000 * \mathrm{Ga} / \mathrm{Al} \mathrm{Vs} \mathrm{Fe}_{2} \mathrm{O}_{3} / \mathrm{Mgo}$ and $\mathrm{K}_{2} \mathrm{O}+\mathrm{Mgo} ; 10000 * \mathrm{Ga} / \mathrm{Al} \mathrm{Vs} \mathrm{Y}$ and Ce Proposed by (Whalen Et Al., 1987) to Distinguish A-Type Granitoids From I- and S-Type (Major Elements in Wt \% and Trace Elements and REE in Ppm) (Symbols as in Fig. 6).
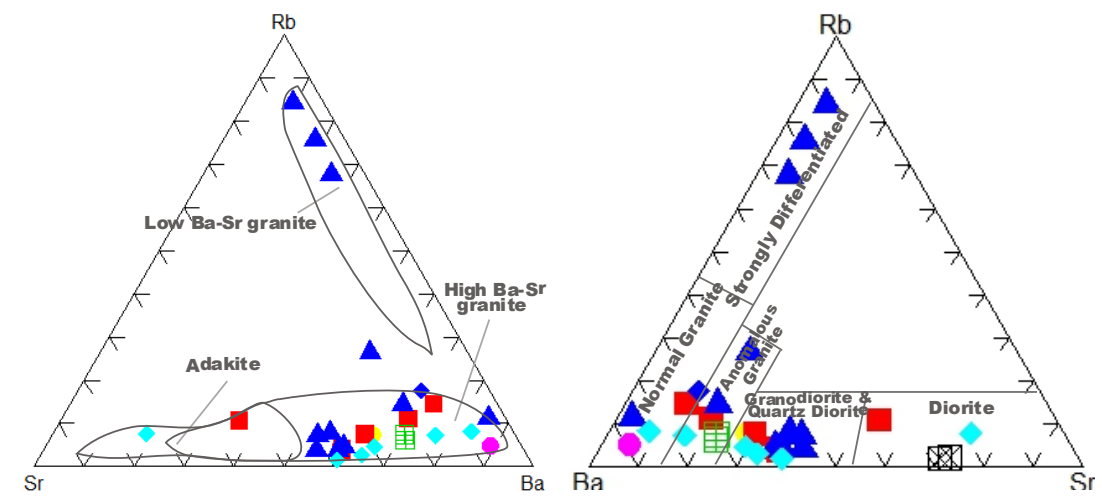

Fig. 18: Sr-Rb-Ba Ternary Diagram After Tarney and Jones (1994) Illustrating the High Ba-Sr Nature and Ba-Rb-Sr Ternary Diagram Showing the Distribution of Granitoids as Diorite; Granodiorite and Quartz Diorite; Anomalous, Normal and Strongly Differentiated Granites (After El Bouseily and El Sokkary, 1975) (Symbols as in Fig. 6). 

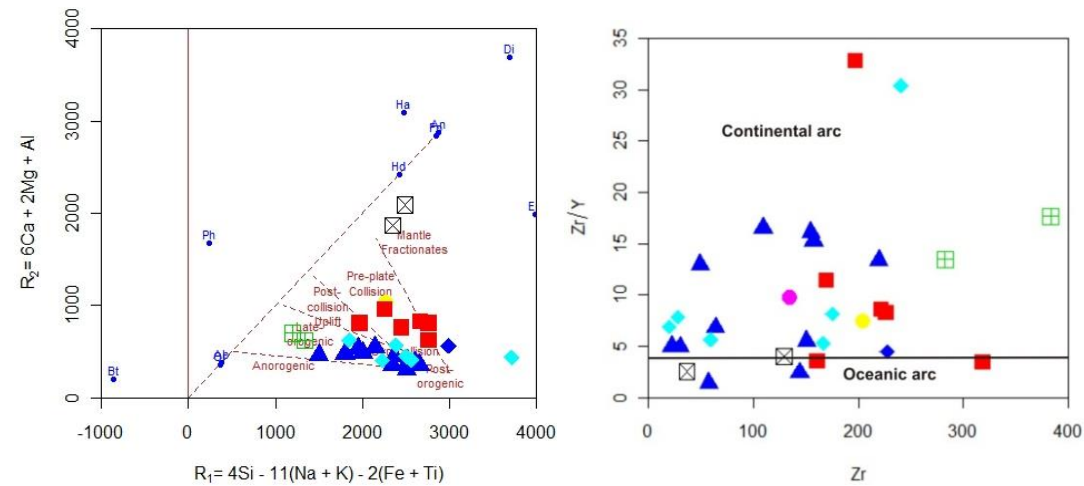

Fig. 19: R1 vs. R2 Diagram of (Batchelor and Bowden, 1985) $\left[\mathrm{R}_{1}=\left(4 \mathrm{Si}-11(\mathrm{Na}+\mathrm{K})-2(\mathrm{Fe}+\mathrm{Ti}) ; \mathrm{R}_{2}=(6 \mathrm{Ca}+2 \mathrm{Mg})+\mathrm{Al}\right)\right]$. and $\mathrm{Zr}$ vs. $\mathrm{Zr} / \mathrm{Y}$ Discrimination Diagram of Pearce (1983) Showing Oceanic and Continental Arc Basalt to Delineate the Tectonic Settings of Granitoids and Basalts (Symbol as in Fig. 6)
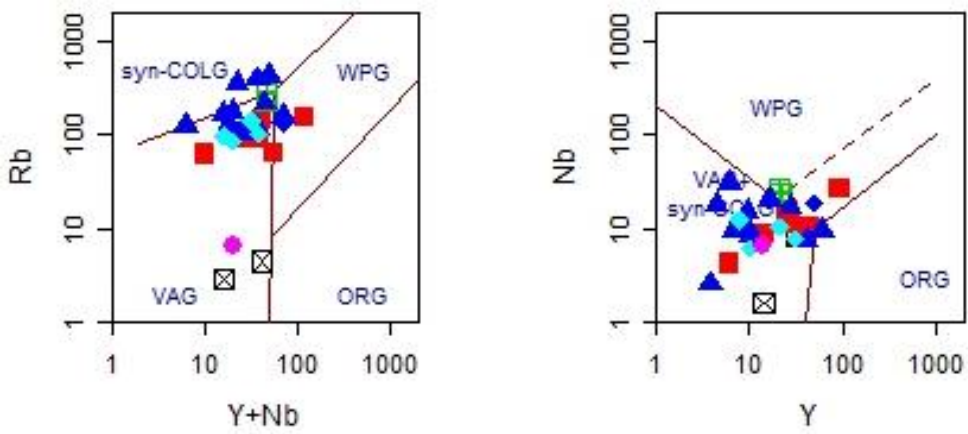

Fig. 20: (A) $(\mathrm{Y}+\mathrm{Nb})$ vs $\mathrm{Rb}$ and (B) Y vs Nb (In Ppm) Geotectonic Discrimination Diagram (After Pearce Et Al., 1984) of the Basalts and Granitoids. ORG=Ocean Ridge Granites, Syn-COLG=Syn-Collisional Granites, VAG=Volcanic Arc Granites, WPG=Within Plate Granites (Symbol as in Fig. 6).

\section{Discussions}

Basalts are massive showing mineral assemblages of olivine + pyroxene + plagioclase + biotite. Granitoids have mineral assemblages of quartz + plagioclase + K-feldspar + biotite + pyroxene + hornblende + muscovite + staurolite. Migmatites of granodioritic compositions and syenites are characterized by mafic microgrannular enclaves. The basement granodioritic paleosome, granitic leucosome and granodioritic granitoid gneiss in Kugu, are typical S-type. The paleosome also are characterized by high temperature quenched clinopyroxene minerals, meaning metamorphism may have reached grannulite facies locally (Oluyede et al., 2021b). The most important petrographic and geochemical evidence for magma mixing is found in the migmatites with alternating S-type mafic paleosome of dioritic and granodioritic composition, granitic leucosome and mafic micro granular enclaves in syenites. Mafic enclaves may reflect mechanical interaction (mingling) and partial chemical hybridization (mixing) of basaltic magma with the host granitoids; which suggest the involvement of mafic mantle-derived magmas in granite petrogenesis as commonly observed within the granitoids suites in the Lachlan Fold Belt (LFB) (Grey, 1984). Evidence of mixing is shown in La/Nb-Ti variation diagram (after Pearce et al., 1990) (Fig. 22A) where basalt samples are gathered in areas close to MORB and OIB, while diorite and granodiorites, syenite with few granites and granite gneiss samples show evidence of mixing; granites samples plot in subduction melt areas. Additionally, $\mathrm{La} / \mathrm{Nb}$ versus $\mathrm{Ba} / \mathrm{Nb}$ plot (after Jahn et al., 1999) (Fig. 22B) shows that basalts might have evolved from primitive mantle with MORB components (Fig. 13) and granitoids of arc volcanics. Moreover, incompatible, LREE and HREE in basalts are characteristically low, which is typical of back arc and MORB (Table 3 and 4; Fig. 13). Wide variation in $\mathrm{SiO}_{2}$ content in the granitoids is usually interpreted as fractional crystallization and is characteristic of I-type granite (Azevedo and Nolan, 1998); its well-defined linear trend might be the result of either hybridization or fractionation (Chappell and Stevens, 1988; Hassanen et al., 1996). The positive and negative correlation with increasing $\mathrm{SiO}_{2}$ and the slightly scattered trend in $\mathrm{K}_{2} \mathrm{O}, \mathrm{Na}_{2} \mathrm{O}$ and $\mathrm{Al}_{2} \mathrm{O}_{3}$ suggests different geological processes, such as mixing or even distinct effects that should be investigated (Rollinson, 1993). Low $\mathrm{SiO}_{2}$ content (49.56 - 49.72) typical of basalts, and relatively uniform composition compared to the granitoids suggests two different compositional trends. The high content of $\mathrm{Na}_{2} \mathrm{O}$ means that Na has not been removed from the source rocks (Chappell and White, 1992). $\mathrm{Na}_{2} \mathrm{O}$ values of $<3 \mathrm{wt} \%$ and high $\mathrm{K}_{2} \mathrm{O} / \mathrm{Na}_{2} \mathrm{O}$ ratios in the dioritic and granodioritic rocks are characteristics of $\mathrm{S}$ - type granite, while $\mathrm{Na}_{2} \mathrm{O}$ with $>3$ wt $\%$ and low $\mathrm{K}_{2} \mathrm{O} / \mathrm{Na}_{2} \mathrm{O}$ ratios in the granite, syenite and $\mathrm{Marinai}$ granodiorite are of I- type granite. Additionally, negative correlation of $\mathrm{P}_{2} \mathrm{O}_{5}$ with increasing $\mathrm{SiO}_{2}$ and low $\mathrm{K}_{2} \mathrm{O} / \mathrm{Na}_{2} \mathrm{O}$ ratios are characteristics of low-temperature I-type granites (Chappell et al., 1988), which may have resulted from fractional crystallization of basalt and dioritic mantle material and partial melting of pre-existing heterogenous metapellitic-amphibolitic protoliths (Sun and Chen, 1992, Robert and Clemens, 1993; Ajaji et al., 1998). The granodiorite and granite and syenite may have been derived from partial melting and variable mixing between mantle-derived mafic magma end members and crustally derived felsic end members (Chappell and White, 1974). General decrease in $\mathrm{CaO}$ content from rock with low $\mathrm{SiO}_{2}$ to high $\mathrm{SiO}_{2}$ is as a result of fractionation of plagioclase, calcic amphibole (hornblende) and biotite.

High $\mathrm{K}_{2} \mathrm{O}$ content (> $2.5 \mathrm{wt} \%$ ), Large Ion Lithophile Elements (LILE) and negative $\mathrm{Nb}$ and $\mathrm{Ti}$ anomaly reinforces the calc-alkaline character and geochemical indication of a subduction related environment (Whalen et al., 1996; Soesoo, 2000; Ferre et al., 1998; Grigoriev and Pshenichny, 1998, Rottura et al., 1998). The positive $\mathrm{Pb}$ anomaly is more pronounced in all the rock types owing to the decay of the high uranium content. The Th/ $\mathrm{U}$ ratios (1.06 - 3.16 in granite, 4.29 - 4.6 in syenite, 3.4 - 5.4 in granodiorite and 0.33 - 4.34 in granite gneiss; and up to 6.64 and 12.0 in granite leucosome and quartzolite respectively) are an indication of contributions from crustal and mantle materials; rocks derived from the upper crust are characterized by ratio $\geq 4$, whereas ratio $<4$ has been related to a mantle contribution (Cullers and Podkovyrov, 2002; Roddaz et al., 2006). Variation in content and behavior of lithophile elements (Ba, $\mathrm{Sr}$ and $\mathrm{Rb}$ ) is very useful in magmatic evolution controlled dominantly by fractional crystallization, partial melting or more complex 
processes (Dall Agnol et al. 1999). Sr- Rb-Ba and Ba- $\mathrm{Rb}-\mathrm{Sr}$ ternary diagram revealed enrichment in $\mathrm{Ba}, \mathrm{Rb}$ and $\mathrm{Sr}$; typical of High $\mathrm{Ba}$ and $\mathrm{Sr}$ granitoids (HiBaSr) as defined by Tarney and Jones (1994) (Fig. 18A) and diverse granite trend such as granodiorite and quartz diorite; normal, anomalous"and strongly differentiated"granite (El Bouseily and El Sokkary, 1975). Strongly differentiated granites are those that are distinctly impoverished in $\mathrm{Ba}$ but enriched in $\mathrm{Rb}$. They represent a very late stage of differentiation. Anomalous granites"are those that have undergone chemical changes (e.g metasomatism) or were not formed by simple mechanism, while normal granites"are those that are characterize by normal"distribution of the three index lithophile elements (El Bouseily and El Sokkary 1975). The wide range of $\mathrm{Rb}$ in the mafic, intermediate and acid rocks (Table 3) is an indication of crustal contamination with mantle materials, and that subduction-related granites have a much wider range of Rb values than the true'ORG (Flagler and Spray, 1991). The Ni concentration in basalts and diorites varies from 51.9 to $134.8 \mathrm{ppm}$ (Table 1) indicating that they might have evolved from primitive mantle as seen from $\mathrm{La} / \mathrm{Nb}$ versus $\mathrm{Ba} / \mathrm{Nb}$ plot (after Jahn et al., 1999) (Fig. 18A). Ni concentrations in tonalities, granodiorites and syenites vary from 14.3 to $35.2 \mathrm{ppm}$ indicating that their source was not primitive mantle but may be a fractionally crystallized depleted mantle (Machado et al., 2005); an indication that mantle materials are from more than one source. This is also validated by the $\mathrm{Zr}$-Ti/1003*Y, Zr-Ti/100-Sr/2 ternary and Zr versus Ti binary diagram (after Pearce and Cann, 1973) (Fig. 23) where basalt plot in MORB and IAT field. Ternary disgram of Mullen, (1983) and Meschede, (1986) also shows basalt plot in the field of back arc and mid ocean ridge basalt (Fig. 24). Slightly higher concentration of $\mathrm{Ni}$ and $\mathrm{Cr}$ in syenite may have resulted in mafic microgrannular enclaves which are harder to melt restite formed during intense metamorphism. Restite is an important constituent in fractional crystallization and igneous differentiation processes and represents the product of quenching of basaltic liquid by I-type granite magma (White, 2001; Flagler and Spray, 1991). Granitoids have also been delineated as continental arc and basalt of oceanic arc from the $\mathrm{Zr}$ vs. $\mathrm{Zr} / \mathrm{Y}$ discrimination diagram of Pearce (1983) (Fig. 19B); this is supported by the post-orogenic plot of $\mathrm{Y}+\mathrm{Nb}$ vs $\mathrm{Rb}$ and the $\mathrm{Y}$ vs $\mathrm{Nb}$ geotectonic discrimination diagram (after Pearce et al., 1984) where basalts and granitoids plot in the volcanic arc and syn-collision granitoid fields respectively (Fig. 23).

A comparison of geochemical characteristics of the granitoids in this study with those from other parts of Nigeria and the world (Table 5) revealed that they are very much similar to those of the Pan-African granitic rocks in the schist belts and those located in the eastern terrane of Nigeria. These characteristics include calc-alkaline, metaluminous and peraluminous character, high iron and LILE enrichment with strong $\mathrm{Nb}$ and $\mathrm{Ti}$ anomaly. Compared with published analyses of basalt and amphibolites from Nigeria and elsewhere in the world (Table 6); the Kushaka Complex basalt are remarkably similar in bulk geochemical compositions, except for its higher Ca and lower Na content. Basalt is characterized by low $\mathrm{K}_{2} \mathrm{O}, \mathrm{Rb}, \mathrm{TiO}_{2}$ and low $\mathrm{Na}_{2} \mathrm{O} / \mathrm{K}_{2} \mathrm{O}$ values (Tables 2 \& 3). This chemistry is consistent with their eruption/emplacement in a zone of oceanic rifting, near a subduction zone. Their tectonic setting is similar to those of most Pan-African granitic rocks whose chemistry is characteristically consistent with an arc or syn-collisional tectonic regime (Fitches et al., 1985; Danbatta, 2002). The high-K calc-alkaline, alkalic to calcic, magnesian and metaluminous character of the Kushaka granitoids make them similar to the Caledonian granitoids, otherwise variously known as high-K alkali-calcic granitoids, post-orogenic granitoids, shoshonitic granitoids and K-rich calc-alkaline granitoids (Frost et al., 2001).

Table 5: Comparison of Geochemical Characteristics of the Granitic Rocks in the Kushaka and the Birnin Gwari Schist Belts with Those in Other Parts of Nigeria and the World

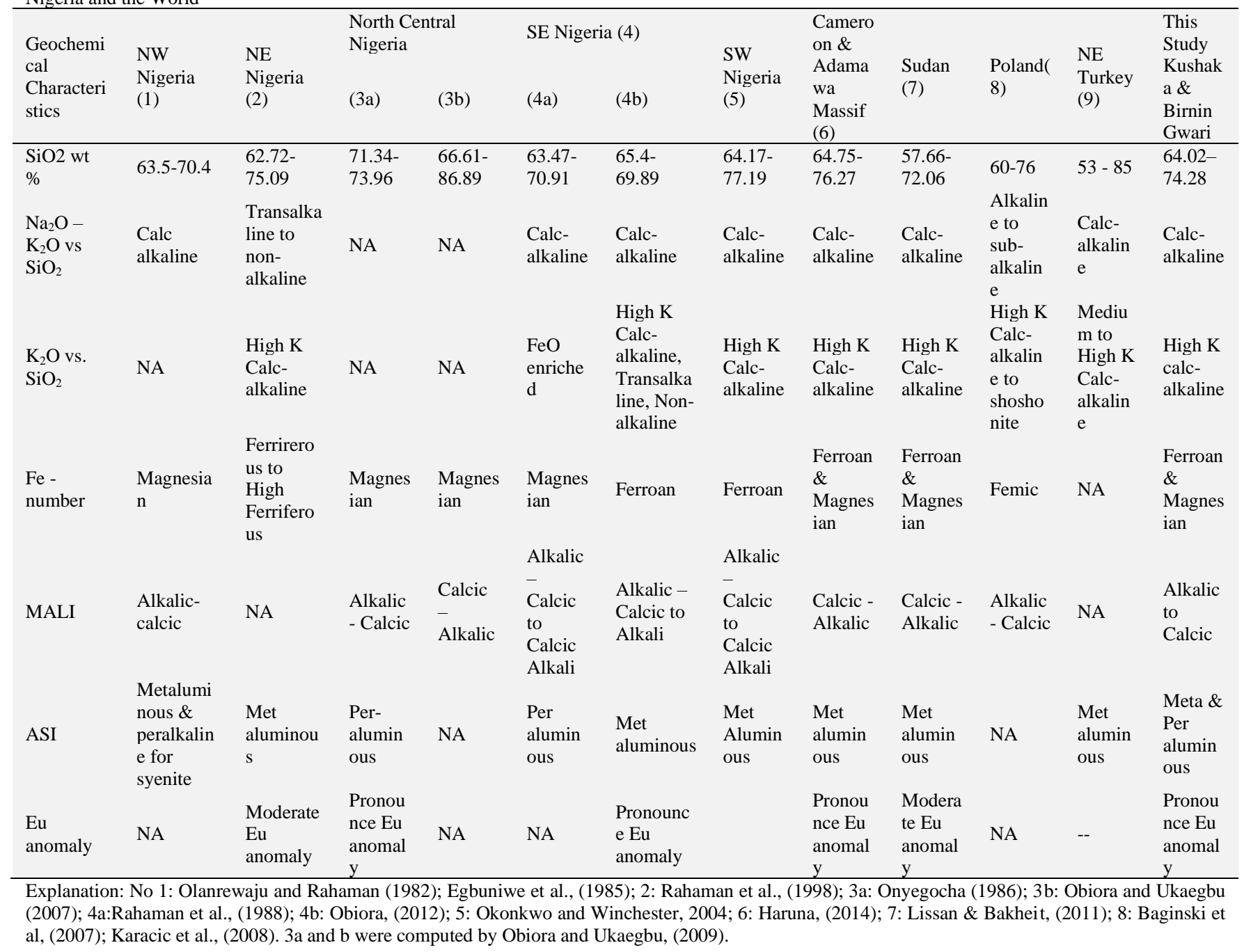


Table 6: Comparison of Analytical Results of Rocks Similar to Basalt of the Kushaka Complex

\begin{tabular}{|c|c|c|c|c|c|c|c|c|c|c|c|}
\hline Sample wt $\%$ & 1 & 2 & 3 & 4 & 5 & 6 & 7 & 8 & 9 & 10 & 11 \\
\hline $\mathrm{SiO}_{2}$ & 49.64 & 49.03 & 47.11 & 51.11 & 50.11 & 46.88 & 49.00 & 51.20 & 51.40 & 49.30 & 51.10 \\
\hline $\mathrm{TiO}_{2}$ & 1.29 & 0.63 & 2.05 & 2.42 & 0.55 & 2.60 & 1.09 & 0.96 & 0.69 & 1.49 & 1.60 \\
\hline $\mathrm{Al}_{2} \mathrm{O}_{3}$ & 14.23 & 22.84 & 16.57 & 13.52 & 14.75 & 20.75 & 14.80 & 15.20 & 14.85 & 17.00 & 16.20 \\
\hline $\mathrm{Fe}_{2} \mathrm{O}_{3}$ & 11.83 & 11.48 & 13.31 & 14.51 & - & 11.46 & - & - & - & - & - \\
\hline $\mathrm{MnO}$ & 0.18 & 0.04 & 0.26 & 0.22 & 0.21 & 0.05 & 0.19 & 0.22 & 0.53 & 0.10 & 0.17 \\
\hline $\mathrm{MgO}$ & 7.88 & 6.63 & 6.59 & 5.04 & 8.56 & - & 6.36 & 6.40 & 6.36 & 7.20 & 6.20 \\
\hline $\mathrm{CaO}$ & 12.20 & 7.83 & 1.08 & 8.75 & 10.34 & 7.80 & 9.75 & 10.70 & 12.16 & 11.70 & 9.90 \\
\hline $\mathrm{Na}_{2} \mathrm{O}$ & 1.40 & 1.55 & 1.65 & 2.79 & 0.63 & 3.25 & 2.07 & 2.80 & 2.19 & 2.70 & 2.51 \\
\hline $\mathrm{K}_{2} \mathrm{O}$ & 0.26 & 0.02 & 0.28 & 1.13 & 0.20 & 0.78 & 0.25 & 0.20 & 0.51 & 0.16 & 0.70 \\
\hline $\mathrm{P}_{2} \mathrm{O}_{5}$ & 0.11 & 0.01 & 0.52 & 0.39 & 0.07 & - & 0.19 & 0.14 & 0.14 & 0.16 & 0.22 \\
\hline \multicolumn{12}{|l|}{ Ppm } \\
\hline $\mathrm{Sr}$ & 144.50 & 3 & 267 & 371 & 45 & - & 124 & 102 & - & 130 & 400 \\
\hline $\mathrm{Zr}$ & 82.90 & 32 & 85 & 220 & 15 & - & 110 & 57 & 130 & 45 & - \\
\hline $\mathrm{Y}$ & 23.40 & 18 & 22 & 49 & 17 & - & 25 & 22 & 36 & 43 & 32 \\
\hline $\mathrm{Ni}$ & 93.85 & 125 & 146 & 59 & 85 & - & 150 & 166 & 123 & 97 & 85 \\
\hline Co & 80.55 & 185 & 46 & - & 28 & 56 & 48 & 60 & 66 & 32 & 39 \\
\hline $\mathrm{Cu}$ & 59.25 & 24 & 124 & 398 & 185 & 99 & 100 & 111 & 68 & 77 & 127 \\
\hline $\mathrm{Zn}$ & 84.05 & 64 & 170 & 109 & - & 60 & 100 & 115 & - & - & 100 \\
\hline
\end{tabular}

1: average Kushaka Basalt (present work); 2: average Zuru amphibolite (Danbatta and Garba, 2007); 3: average Ilesha, amphibolite, SW Nigeria (Olade and Elueze, 1979); 4: average Jebba amphibolite, SW Nigeria (Okonkwo and Winchester, 1996); 5: average Burum amphibolite, Central Nigeria (Elueze and Okunlola, 2003); 6: average Obudu amphibolite NE Nigeria (Ejimofor et al., 1996); 7: average Archaan metabasalt, Canadian Shield (Glikson, 1971); 8: average Archaen metabasalt, W. Australia (Hallberg, 1972); 9: average Dhowar metavolcanis, India (Naqvi and Hussain, 1973); 10: average Oceanic tholeiite (Engel et al., 1965); 11: average tholeiitic basalt (Manson, 1967; Prinz, 1967).
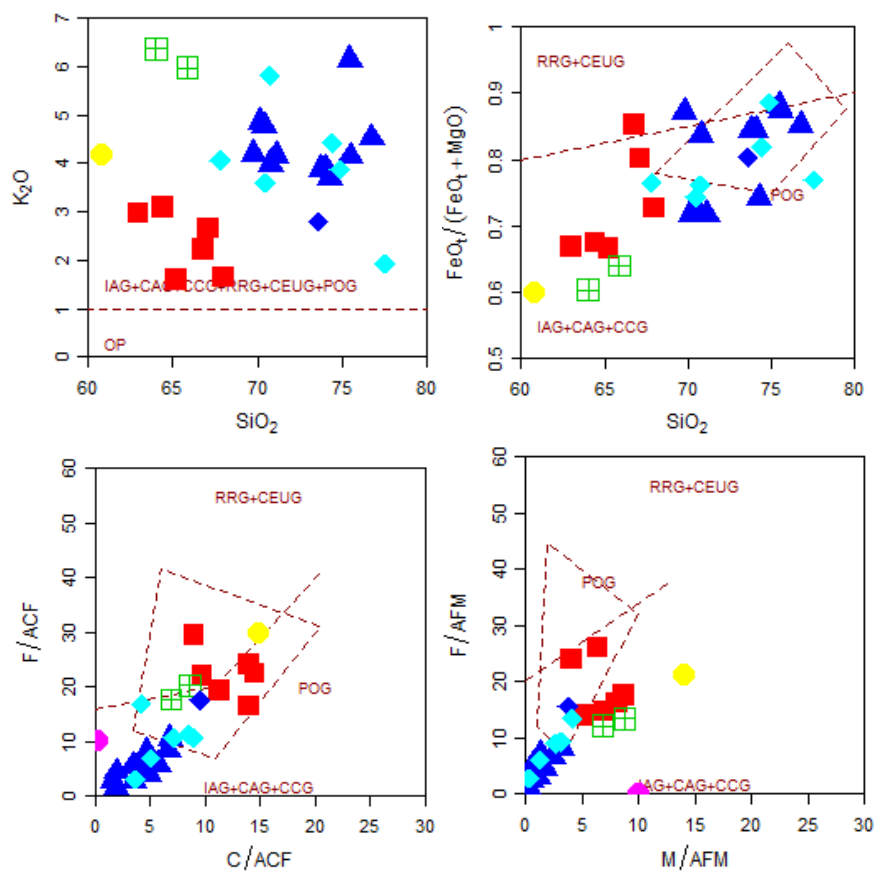

Fig. 21: Major Element Based Geotectonic Classification of the Granitoids (A) $\mathrm{Sio}_{2} \mathrm{vs}_{2} \mathrm{O}$; (B) M/AFM vs F/AFM; (C) $\mathrm{Sio} / 2$ vs Fe $\mathrm{O}_{3} /\left(\mathrm{Fe}_{2} \mathrm{O}_{3}+\mathrm{Mgo}\right.$ ); (D) C/ACF vs F/ACF (After Maniar and Piccoli, 1989). Field IAG=Island Arc Granitoids, CAG=Continental Arc Granitoids, CCG=Continental Collision Granitoids, CEUG=Continental Epeirogenic Uplift Granitoids, OP=Oceanic Plagiogranites (Symbols as in Fig. 6).
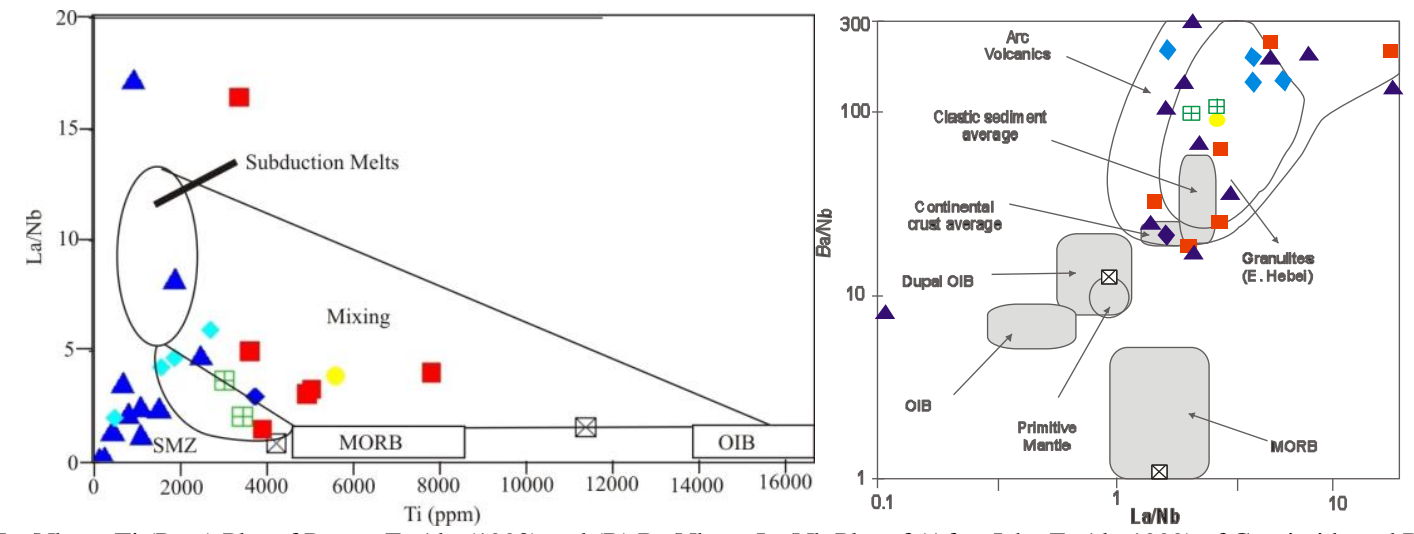

Fig. 22: (A) La/Nb vs. Ti (Ppm) Plot of Pearce Et Al., (1990) and (B) Ba/Nb vs. La/Nb Plot of (After Jahn Et Al., 1999) of Granitoids and Basalt Showing Magma Mixing and Setting. SMZ=Sub-Duction Zone Magmatites; MORB=Mid Ocean Ridge Basalt; OIB=Ocean Island Basalt (Symbols as in Fig. 6). 

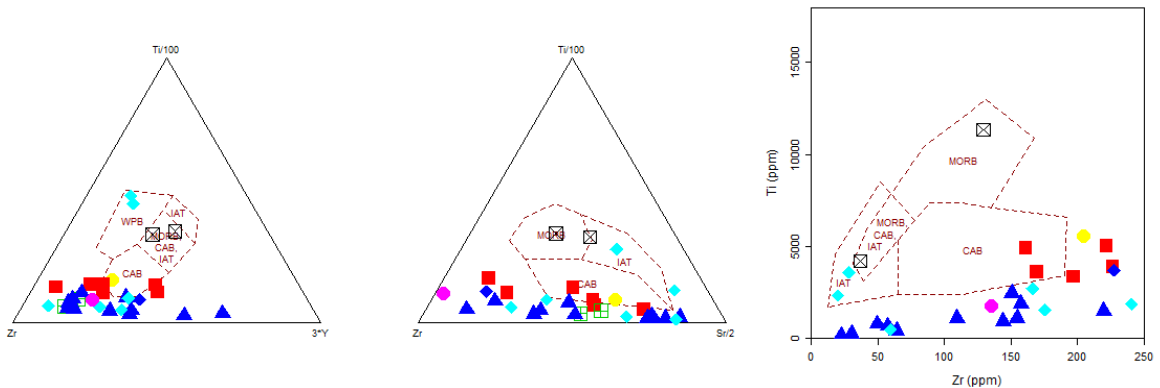

Fig. 23: Zr-Ti/100-3*Y, Zr-Ti/100-Sr/2 Ternary and Zr versus Ti Binary Basalt Tectonic Discrimination Diagram (After Pearce and Cann, 1973) (Symbols as in Fig. 6).

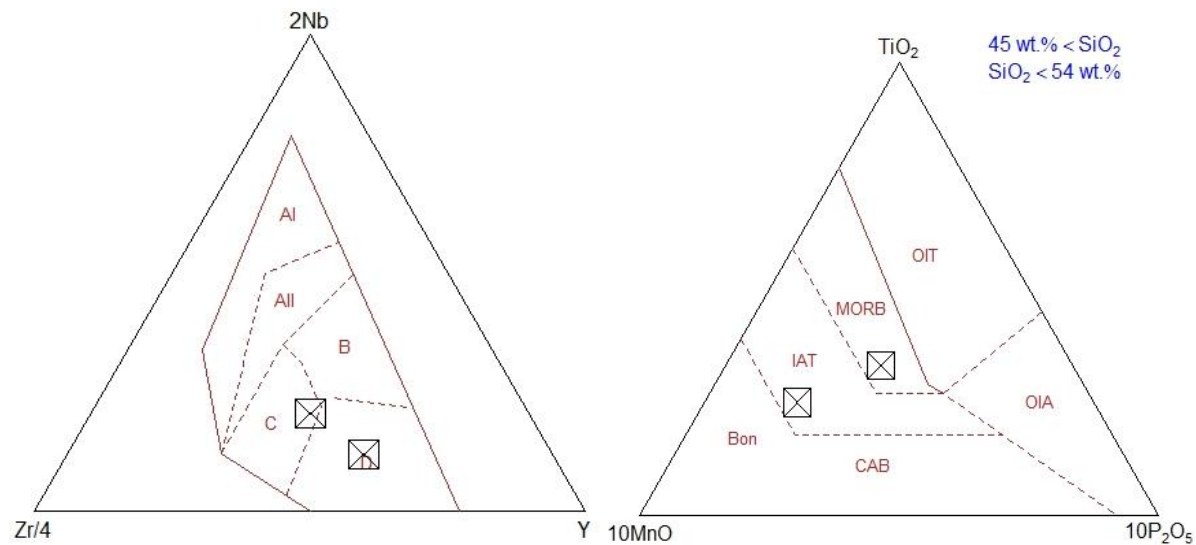

Fig. 24: 2Nb-Zr/4-Y (After Meschede, 1986) and $\mathrm{Tio}_{2}-10 \mathrm{mno}-10 \mathrm{P}_{2} \mathrm{O}_{5}$ (After Mullen, 1983) Ternary Diagram Basalt Tectonic Discrimination Field for Basalts. AI=Within Plate Basalts, AII=Within Plate Tholeiite Basalts, B=MORB, C=Back Arc Basalts, D=Volcanic Arc Basalts; IAT=Island Arc Tholeiite, MORB=Mid Ocean Ridge Basalts, OIT=Ocean Island Tholeiite, OIA=Ocean Island Arc, CAB=Continental Arc Basalt.

The collision that resulted in the evolution of magmatic rocks took place under extensional and compressional regimes, and preceded by / or contemporaneous with subduction of the lithosphere beneath an ancient oceanic crust at the eastern margin of the West African craton underneath the Tuareg shield (Obiora, 2006, 2012); this resulted in Eburnean and Pan-African deformations as well as Pan-African intrusion of calc-alkaline granites and volcanics (Danbatta, 2010) supported by the presence of basic to ultrabasic rocks such as extrusive basalt in the Kushaka schist belt (Oluyede, et al., 2021a) and calc-alkaline volcanics and hypabyssal rocks in the Anka schist belt (Agunleti et al., 2020) in the Nigerian sector. This has also resulted in characteristics ophilitic complexes and a high positive gravity anomaly in a narrow zone within the Dahomeyide orogen, located at the southeastern margin of the West African Craton in Togo and the Benin Republic (Schluter, 2005). Comparison of geochemical characteristics and ages of these granitoids with others Pan-African granitoids in different parts of Nigeria (notably in southwest, southeast, north-central, northwest, and northeast) revealed their similarities and their relation to the Pan-African granites also referred to as Older Granite. All the ages determined from the granitoids are Pre- and Pan-African while the Pan-African granites showed consistency and correlates well (Table $1 \& 5$ ).

\section{Conclusion}

Petrographic and geochemical data have revealed that the Kushaka and Birnin Gwari granitoids and associated volcanic rocks consist dominantly of diorite, granodiorite, tonalite, granite, and granitoid gneisses and basalt. The early granitoids are product of metasomatism and granitic injections while the later granitoids are syn-tectonic and late orogenic. Plagioclase, biotite, hornblende, pyroxene and olivine fractionation played an important role during their genesis through a continuous fractional crystallization of basaltic and partial melting of older dioritic-granodioritic source rock in the deep crust which were themselves ultimately derived through fusion of mantle materials contaminated by continental crust and enriched by fluids derived from the oceanic crust in an arc setting. They are characteristics by two different geochemical trends; mixed tholeiitic and calc-alkaline character, ferroan and magnesian, metaluminous and peraluminous, Iand $\mathrm{S}$-type components with selective enrichment in $\mathrm{Pb}, \mathrm{Rb}$, Th, $\mathrm{Ba}$ and depletion in $\mathrm{Nb}, \mathrm{Sr}, \mathrm{P}$ and $\mathrm{Ti}$ in volcanic arc and syn-collisional setting. The granitoids revealed enrichment in $\mathrm{Ba}, \mathrm{Rb}$ and $\mathrm{Sr}$; typical of High $\mathrm{Ba}$ and $\mathrm{Sr}$ granitoids (HiBaSr) and with diverse granite trend such as granodiorite and quartz diorite; normal, anomalous"and strongly differentiated; contaminated with mantle materials and their source may be a fractionally crystallized depleted mantle. Basalts are tholeiitic with $\mathrm{Fe}$ and $\mathrm{Mn}$ enrichment and have evolved from primitive mantle; indications that mantle materials are from more than one source, and originated as back arc and mid-ocean ridge (MORB) type. Basaltic magmas from the sub-circular Kushaka Complex has resulted in complete change in the genesis of magma in this region. Granitoids and their associated rocks may have formed behind subducted Pan-African plate due to the effects of tensional forces caused by oceanic plate roll-back which leads to a zone of extension parallel to the island arc. Granitoids are similar to others in the Nigerian Basement Complex and schist belts in the north and eastern parts of the Pan-African mobile belt, while associated volcanic rocks are similar to to ophiolites and amphibolites in other schist belts in Nigeria schist belts in Nigeria forming a lateral continuation of the same mobile belt.

\section{Acknowledgement}

The authors equally acknowledged the assistance of Mr Adekunle Omokanye for his assistance as a guide during the field mapping exercise. We are indebted to the staff of Geochronology Laboratory for their efforts in carrying out the geochemical analysis for the 
whole rock major and trace elements, and Dr Abdulrasak Garba, Director General, Nigeria Geological Survey Agency, Abuja for his assistance in the REE analysis. Insights and contributions of Prof. Abba and Prof. Ajibade in the course of this work are greatly acknowledged. The efforts of Prof. Najime Tavershima, Head, Geology Department, Dr S. S. Magaji, Mr. A.K. Amuda and Mr Animashaun of the Department of Geology, Ahmadu Bello University Zaria are equally acknowledged. The help of Peter Nagl, University of Vienna, with the whole rock geochemical analysis is also acknowledged.

\section{References}

[1] Ajaji, T., Weis, D., Giret, A. and Bouabdellah, M. (1998). Coeval potassic and sodic calc-alkaline series in the post-collisional Hercynian Tanncherfi intrusive complex, Northeastern Morrocco: geochemical, isotopic and geochronological evidence. Lithos 45, 371-393. https://doi.org/10.1016/S0024-4937(98)00040-1.

[2] Adegbuyi, O. 1, Ogunyele, A. C., Odindu, M., and Erinfolami, T. 2017. Geochemical Characteristics and Petrogenesis of Basement Rocks in Idoani Area, Ondo State, Southwestern Nigeria. International Journal of Advanced Geosciences, 5 (2), 102-108 https://doi.org/10.14419/ijag.v5i2.8377.

[3] Adekoya, J. A. 1996. The Nigerian schist belts: age and depositional environment. Implications from associated banded iron-formations. Journal of Mining Geology, Nigeria 32, 35-46.

[4] Ajibade. A. C, Woakes, M., and Rahaman M.A (1987): Proterozoic Crustal Development in the Pan-African Regime of Nigeria. In: C. A. Kogbe (edition) "Geology of Nigeria" 2nd revised edition Rock View Nigeria limited Jos, pp. 57-69. https://doi.org/10.1029/GD017p0259.

[5] Ajibade A. C., Anyanwu, N. P. C., Okoro, A. U. and Nwajide, C. S. (2008). The Geology of Minna area. Nigeria Geological Survey Agency Bulletin No 43.

[6] Ajibade, A. C. and Fitches, W. R. In: P. O. Oluyide 1988. (ed.) Precambrian Geology of Nigeria, Geological Survey Publication, Nigeria, pp. 4553.

[7] Agunleti, Y. S., Najime, T., Ibrahim, A. A. and Magaji, S. S. (2020). Geology and petrographic studies of rocks in Anka sheet 52, Northwestern Nigeria. Journal of Environmental and Earth Sciences. Vol. 10, No. 53-66.

[8] Akinola, O. O., Talabi, A. O. and Muhammad, H. R. (2017). Petrostructural Features of Metaconglomerate in Igarra and Otuo, South-Western Nigeria. Asian Journal of Earth Sciences, 10, 33-43. https://doi.org/10.3923/ajes.2017.33.43.

[9] Alaku, I. O., Moshood, O. I., Agbor, A. T. and Amos, A. A. 2017. Geochemical Characteristic and Petrogenesis of Malumfashi Schist around Tandama Area, North-Western Nigeria. British Journal of Applied Science \& Technology 20(1): 1-14, 2017. https://doi.org/10.9734/BJAST/2017/30116.

[10] Ananaba, S. E., Ajakaye, D. E., 1987. Evidence of tectonic control of mineralization in Nigeria from lineament density analysis. A Landsat study. Intl. Journal of Remote Sensing 10, 1445-1452. https://doi.org/10.1080/01431168708954788.

[11] Annor, A. E. (1995): U-Pb zircon age for Kabba-Okene granodiorite gneiss: implications for Nigeriaecs basement chronology. Africa Geoscience Review, 2: pp. 101-105.

[12] Annor, A. E. (1998): Structural and chronological relationship between the low grade Igarra schist and its adjoining Okene migmatite-gneiss terrain in the Precambrian exposure of southwestern Nigeria. Journal of Mining and Geology, 34: PP. 187-196.

[13] Azevedo, M. R. and Nolan, J. (1998). Hercynian late-post-tectonic granitic rocks from the Fornos de Algodres area (North Central Portugal). Lithos 44, 1-20. https://doi.org/10.1016/S0024-4937(98)00019-X.

[14] Baginski, B., Duchesne, J., Martin, H. and Wiszniewska, J., (2007). Isotopic and geochemical constraints on the evolution of the Mazury granitoids, NE Poland. AM Monogragh No. 1, pp. 1130.

[15] Batchelor, R. A, Bowden, P. (1985): Petrogenetic interpretation of granitoid rock series using multicationic parameters. Journal of Chemical Geology 48: pp. 43-55 https://doi.org/10.1016/0009-2541(85)90034-8.

[16] Boynton W.V. 1984. Cosmochemistry of the rare earth elements; meteorite studies. In: Henderson P. (Ed.). Rare Earth element geochemistry. Amsterdam: Elsevier. p. 63-114. https://doi.org/10.1016/B978-0-444-42148-7.50008-3.

[17] El-Bouseily, A.M. and El-Sokkary A.A (1975): The relationship between Rb,Sr and Ba in granitic rocks. Journal Of chemical geology 16: pp. 207219 https://doi.org/10.1016/0009-2541(75)90029-7.

[18] Bruguier, O., Dada. S.; and Lancelot, J.R (1994): Early Archaean component ( >3.5 Ga) within a 3.05 Ga orthogneiss from northern Nigeria: U-Pb zircon evidence. Earth Planet. Sci. Lett. 125, pp 89-103. https://doi.org/10.1016/0012-821X(94)90208-9.

[19] Caby, R. (1989). Precambrian terranes of the Benin-Nigeria and Northeast Brazil and the late Proterozoic SouthAtlantic fit. Geological Society of America Special Paper, 230: pp. 145-158. https://doi.org/10.1130/SPE230-p145.

[20] Caby, R. and Boesse, M. (2001): Pan African nappe system in southwest Nigeria: the Ife -Ilesha schist belt. Journal of African Earth Sciences, 33: pp. 211-225. https://doi.org/10.1016/S0899-5362(01)80060-9.

[21] Chappell, B.W and White, A.J.R. (1992): I- and S-type granites in the Lachlan Fold Belt. Journal of Earth Science 83: pp. 1-26. https://doi.org/10.1130/SPE272-p1.

[22] Chappell B. W. and Stephens W. E. (1974). Origin of infracrustal (I-type) granite magmas. Transactions of the Royal Society of Edinburgh: Earth Sciences 79, 71-86. https://doi.org/10.1017/S0263593300014139.

[23] Chappell B. W. Bryant, C. J., Wyborn, D., White A. J. R and Williams I. S. 1998. High- and low-temperature I-type granites. Resource Geology 48, 225-226. https://doi.org/10.1111/j.1751-3928.1998.tb00020.x.

[24] Cocherie, A. 1986. Systematic Use of Trace Element Distribution on Patterns in Log-Log Diagrams for Plutonic Suites. Geochimica et Cosmoshimica Acta, 50, 2517-2522. https://doi.org/10.1016/0016-7037(86)90034-7.

[25] Cooray, P., 1974. Some aspect of the Precambrian of Nigeria: A review. Jour. of Min.and Geol Nig. 8(1), 17-43.

[26] Cox, K. G., Bell, J. D., Pankhurst, R. J., (1979). The interpretation of igneous rocks, George, Allen and Unwin, London. https://doi.org/10.1007/978-94-017-3373-1.

[27] Cullers R. L., Podkovyrov V. L., (2002). The source and origin of terrigenous sedimentary rocks in the Mesoproterozoic Ui group, Southeastern Russia. Precambrian Research. 117(3):157-183. https://doi.org/10.1016/S0301-9268(02)00079-7.

[28] Dada, S. S. 1998. Crust-forming ages and Proterozoic crustal evolution in Nigeria: of current interpretations. Precambrian Research 87, 65-74. https://doi.org/10.1016/S0301-9268(97)00054-5.

[29] Dada, S.S., Lancelot, J.R., Briqueu, L., 1989. Age and origin of the annular charnockitic complex at Toro, Northern Nigeria: U--Pb and RbSr evidence. Journal of African Earth Sciences, 9, pp. 227-234. https://doi.org/10.1016/0899-5362(89)90066-3.

[30] Dada, S. S., Birck, J. L., Lancelot, J. R. and Rahaman, M. A. (1993): Archean migmatite-gnesis complex of North Central Nigeria: its geochemistry, petrogenesis and crustal evolution. In: 16th International Colloquium on African Geology, Mbabane, Swaziland, Extended Abstracts, 1: pp. 97-102.

[31] Dall"eAgnol, R., Ramo“, O.T., Magalhaes, M.S., and Macambira, M.J.B., (1999): Petrology of the anorogenic oxidised Jamon and Musa granites, Amazonian craton: implications for the genesis of Proterozoic A-type granites. Lithos 46: pp. 431- 462 https://doi.org/10.1016/S00244937(98)00077-2.

[32] Danbatta, U. A. 1999. Geotectonic evolution of the Kazaure schist belt in the Precambrian Basement of NW Nigeria. Unpublish. Ph.D. Thesis, Ahmadu Bello University, Zaria.19-42.

[33] Danbatta. U. A. 2002. Rb-Sr Isochron Dating of Granitoids from the Kazaure Schist Belt, NW Nigeria. Global Journal of Pure and Applied Sciences 8 (3). 319-322 https://doi.org/10.4314/gjpas.v8i3.16015. 
[34] Danbatta, U.A. (2008): A Review of the Evolution and Tectonic Framework of the Schist Belts of Western Nigeria, West Africa. Africa geoscience review15 (2): pp. 145-158.

[35] Danbatta. U. A. 2010. On the evolution of Kazaure Schist Belt of NW Nigeria. Global Journal of Geological Sciences 8 (2). 207-216 https://doi.org/10.4314/gjgs.v8i2.62775.

[36] Ekwueme, B. N., 1987. Structural orientation and Precambrian deformational episode of Uwet area, Oban Massif, S.E. Nigeria. Precambrian Research, 34, pp. 269- 289. https://doi.org/10.1016/0301-9268(87)90004-0.

[37] Ekwueme, B. N., and Kroner, A., 1994. The nature of the Archean crust in Nigeria: a new discovery. United State Geological Survey Circular, 1107.

[38] Ekwueme, B.N. and Kroner, A., 1998. Single zircon evaporation ages from the Oban Massif, southeastern Nigeria. Journal of African Earth Sciences, 26, 195 - 205. https://doi.org/10.1016/S0899-5362(98)00005-0.

[39] Ekwueme, B. N. \& Shing, R., (1987). Occurrence, Geochemistry and Geochronology of mafic-Ultramafic rock in the Obudu Plateau S.E. Nigeria in Srivasta R.K. and Chadta, R. (eds) Magmatism relation to diverse tectonic settings.

[40] El Bouseily, A. M and El-Sokkary, A. A., 1975. The relationship between Rb, Sr and Ba in granitic rocks. Chemical Geology. 16, 174-189. https://doi.org/10.1016/0009-2541(75)90029-7.

[41] Elueze, A. A. (1981). Dynamic metamorphism and oxidation of amphibolites of Tegina Area, North-western Nigeria. Precambrian Research. 14(3):379-388. https://doi.org/10.1016/0301-9268(81)90046-2.

[42] Elueze, A. A. and Okunlola, O. A. 2003. Geochemical features and petrogenetic affinity of Precambrian amphibolites of Burum area Central Nigeria. Nigerian Journal of Mining and Geology, 39(2), 7 pp. 1-78. https://doi.org/10.4314/jmg.v39i2.18794.

[43] Engel, A.E.J., Engel, C.G. and Havens, R.G. 1965. Chemical characteristics of oceanic basalts and the upper mantle. Geol. Soc. Am. Bull. 76, pp. 719-734. https://doi.org/10.1130/0016-7606(1965)76[719:CCOOBA]2.0.CO;2.

[44] Ejimofor, O. C., Umeji, A. C. and Turaki, U. M. 1996. Petrography and major element geochemistry of the basement rocks of northern Obudu area, eastern Nigeria. Journ. Min. Geol., 32, pp. 1-9.

[45] Ezepue, M. C and Odigi, M. I., 1993. Petrology and geochemistry of monzodiorite, granodiorite and granites from the Precambrian terrain between Kabba and Lokoja, SW Nig. Jour. Min. Geol; 30, (1): 1-9.

[46] Falconer, J. D. 1911. The Geology and Geography of Northern Nigeria. Macmillian, London.

[47] Ferre, E. C., Caby, R., Peucat, J. J., Capdevila, I. R., and Monie, P., 1998. Pan-African post-collisional, ferro-potassic granite and quartz-monzonite plutons of Eastern Nigeria. Lithos, 45, pp. 255 278. https://doi.org/10.1016/S0024-4937(98)00035-8.

[48] Flagler, P. A., Spray, J. G., 1991. Generation of plagiogranite by amphibolite anatexis in oceanic shear zones. Geology 19, 70-73. https://doi.org/10.1130/0091-7613(1991)019<0070:GOPBAA>2.3.CO;2.

[49] Fitches, W. R., Ajibade A. C., Egbuniwe I. G., Holt R. W., and Wright J.B. (1985): Late Proterozoic Schist Belts and Plutonism in NW Nigeriae, Geological Society of London, 142: pp. 319- 337. https://doi.org/10.1144/gsigs.142.2.0319.

[50] Frost, C. D., Frost. B. R., Chamberlain, K. R., \& Edwards, B. R. (1999). Petrogenesis of the 1.43 Ga Sherman batholith, SE Wyoming: a reduced rapakivi-type anorogenic granite. Journal of Petrology, 40, 1771-1802. https://doi.org/10.1093/petroj/40.12.1771.

[51] Frost, B. R., Barnes, C. G., Collins, W. J., Arculus, R. J., Ellis, D. J., \& Frost, C. D. (2001). A geochemical classification for granitic rocks. Journal of Petrology, 42, 2033-2048. https://doi.org/10.1093/petrology/42.11.2033.

[52] Ferre, E.C, Deleris, J, Bouchez, J.L, Lar, A.U., and Peucat, J.J (1996): The Pan-African Reactivation of Eburnean and Archaen Provinces in Nigeria: Structural and Isotopic Data. In: Journal of the Geological Society, London, 153: pp. 719-728. https://doi.org/10.1144/gsjgs.153.5.0719.

[53] Ferre, E. C., Caby, R., Peucat, J. J., Capdevila, I. R., \& Monie, P. (1998). Pan-African post-collisional ferro-potassic granite and quartz-monzonite plutons https://doi.org/10.1016/S0024-4937(98)00035-8.

[54] Garba, I. 2002. Late Pan-African tectonics and origin of Gold mineralization and Rare-metal pegmatites in the Kushaka schist belt, northwestern Nigeria. Journal of Mining and Geology. 38, 1, 1-12. https://doi.org/10.4314/jmg.v38i1.18768.

[55] Glikson, A.Y. 1971. Primitive Archaen element distribution patterns: chemical evidence and geotectonic significance. Earth Planet. Sci. Lett. 12, pp. 309-320. https://doi.org/10.1016/0012-821X(71)90215-9.

[56] Goodenough, K. M., Lusty, P. A. J., Roberts, N. M. W., Key, R. M. and Garba, A. 2014. Post-collisional Pan-African granitoids and rare metal pegmatites in western Nigeria: Age, petrogenesis, and the 'pegmatite conundrum'. Lithos 200, 22-34 https://doi.org/10.1016/j.lithos.2014.04.006.

[57] Grant, N.K. (1970): Geochronology of Precambrian Basement Rocks from Ibadan, southwestern Nigeria. Earth and Planetary Science Letters 10: pp. 29-38 https://doi.org/10.1016/0012-821X(70)90061-0.

[58] Grant, N. K. Hickman, M., Burkholder, F. R. and Powell, J. L. 1972. Kibaran Metamorphic Belt in the Pan-African Domain of W. Africa. Nature (London). 134, 343-349.

[59] Grant, N. K. 1978. Structural distinction between metasedimentary cover and an underlying basement in the 600 m.y. old Pan-African domain of Northwestern Nigeria, West African. Geological Society America Bulletin 89, 50-58. https://doi.org/10.1130/00167606(1978)89<50:SDBAMC >2.0.CO;2.

[60] Gray, C. M. 1984. An isotopic mixing model for the origin of granitic rocks in southern Australia Earth and Planetary Science Letters 70, 47-60. https://doi.org/10.1016/0012-821X(84)90208-5.

[61] Grigoriev, S. I. and Pshenichny, C. A., 1998. Late Mesozoic post-collisional intermediate to silicic magmatism in the Badjal area, far east of Russia. Lithos 45, 457-468. https://doi.org/10.1016/S0024-4937(98)00044-9.

[62] Guimarāes, I. P., Da Silva Filho, A. F., Almeida, C. N,. Van - Schmus, W. R. Araújo, J. M. M. Melo, S. C. Melo, E. B. 2004. Precambrian Research, 135, 23-53 https://doi.org/10.1016/j.precamres.2004.07.004.

[63] Hallberg, J.A. 1972. Geochemistry of Archaen volcanic belts in the Eastern Goldfields region of Western Australia. J. Petrol., 13 , 45-66. https://doi.org/10.1093/petrology/13.1.45.

[64] Hassanen M.A., El-nisr S.A., and Mohamed F.H (1996): Geocheinistry and petrogenesis of Pan-African I-type granitoids at Gabal Igla Ahmar, Eastern Desert, Egypt Journal of African Earth Science 22,( 1): pp. 29-42 https://doi.org/10.1016/0899-5362(95)00122-0.

[65] Irvine, T. N., and Baragar, W. R. A. 1971. A Guide to the Chemical Classification of Common Volcanic Rocks. Canadian Journal of Earth Sciences, 8, (5), 523-548. doi:10.1139/e71-055 https://doi.org/10.1139/e71-055.

[66] Jahn, B. M. Wu, F. Lo C. H. and TsaI, C. H. 1999. Crust-Mantle İnteraction İnduced by Deep Subduction of the Continental Crust: Geochemical and Sr-Nd İsotopic Evidence from Post-Collisional Mafic-Ultramafic İntru- sions of the Northern Dabie Complex, Central China. Chemical Geology. Vol. 157, No. 1, pp. 119-146. https://doi.org/10.1016/S0009-2541(98)00197-1.

[67] Jensen, L. S. (1976). A new cation plot for classifying subalkalic volcanic rocks. Ont. Div. Mines Misc. Paper 66: 1-22.

[68] Karacik, Z., Yilmaz, Y., Pearce, J. A. and Ece, O. I., 2008. Petrochemistry of the south Marmara granitoids, northwest Anatolia, Turkey. International Journal of Earth Sciences (Geol Rundsch), 97, pp. 1191-1200. https://doi.org/10.1007/s00531-007-0222-y.

[69] Kröner, A., Ekwueme, B.N. and Pidgeon, R.T. (2001): The Oldest Rocks in West Africa: SHRIMP Zircon Age for Early Achean Migmatitic Orthogneiss at Kaduna, Northern Nigeria. Journal of Geology, university of Chicago, 19: pp. 399-406. https://doi.org/10.1086/319979.

[70] Lissan, H. N., Bakheit, A. K.., 2011. Geochemistry and geotectonic setting of Neoproterozoic Granitoids from Artoli Area, Berber Province Northern Sudan. Journal of Applied Sciences. 11 (5), 752-767. https://doi.org/10.3923/jas.2011.752.767.

[71] Long, L. E., Castellana, C.H., and Sial, A. N. 2005. Age, Origin and Cooling History of the Coronel Joao Sa Pluton, Bahia, Brazil. Journal of Petrology 45, 255-273. https://doi.org/10.1093/petrology/egh070.

[72] Machado, A. Lima, E. F. Chemale, F. J. 2005. Geoche- mistry Constraints of Mesozoic-Cenozoic Calc-Alkaline Magmatism in the South Shetland Arc, Antarctica. Journal of South American Earth Sciences. Vol. 18, No. 3-4, pp. 407-425. https://doi.org/10.1016/j.jsames.2004.11.011. 
[73] Maniar, P. D. and Piccoli, P. M., 1989. Tectonic discrimination of granitoids. Geological Society of American Bulletin, 101, pp. 635 -643.Manson, V. 1967. Geochemistry of basaltic rocks: major elements. In: Hess H.H. and Poldervaart, A. (eds.) Basalts 2 Interscience New York, pp. 15-39. https://doi.org/10.1130/0016-7606(1989)101<0635:TDOG>2.3.CO;2.

[74] McCurry, P. 1976. The geology of the Precambrian to Lower Palaeozoic of northern Nigeria- a review. In: Geology of Nigeria. C.A. Kogbe (Ed). Elizabethan Publishing Company. Lagos, 15-39

[75] Meschede, M., 1986. A method of discriminating between different types of mid-ocean ridge basalts and continental tholeiites with the Nb-Zr-Y diagram. Chemical Geology 56, 207-218. https://doi.org/10.1016/0009-2541(86)90004-5.

[76] Middlemost E.A.K. 1985 Magmas and magmatic rocks: an introduction to igneous petrology. London/New York, Longman, 266 p.

[77] Miyashiro A (1978). Nature of alkalic volcanic rock series. Contrib. Mineral Petrol. 66: 91-104. https://doi.org/10.1007/BF00376089.

[78] Mucke, 2005. The Nigerian manganese-rich iron-formations and their host rocks - from sedimentation to metamorphism. Journal of African Earth Sciences. 41, 407 - 436. https://doi.org/10.1016/j.jafrearsci.2005.07.003.

[79] Mullan, H. S. (1979): Structural distinction between a metasedimentary cover and an under lying basement in the 600 m.y. old Pan African domain of northwestern Nigeria, West Africa: discussion. Geological Society of America Bulletin 90: pp. 983-984 https://doi.org/10.1130/00167606(1979)90<983:SDBAMC>2.0.CO;2

[80] Mullen, E. D., 1983. MnO/TiO2/P2O5: a minor element discriminant for basaltic rocks of oceanic environments and its implications for petrogenesis. Earth Planetary Science Lettwrs Vol. 62, (1), 53-62 https://doi.org/10.1016/0012-821X(83)90070-5.

[81] Naqvi, S. M., and hussain, S. M. 1973. Geochemistry of Dhawar Metavolcanics and composition of the primeval crust of the peninsular India. Geochim. Cosmochim. Acta 37, pp. 159-164. https://doi.org/10.1016/0016-7037(73)90254-8.

[82] Obiora, S. C., 2006. Petrology and Geotectonic Setting of B asement Complex Rocks around Ogoja, Southeastern Nigeria. Ghana Journal of Science, 46, pp. 13 - 25. https://doi.org/10.4314/gjs.v46i1.15912.

[83] Obiora, S. C. (2012): Chemical characterization and tectonic evolution of hornblende-biotite granitoids from the Precambrian Basement Complex around Itowanye and Katsina-Ala, southeastern Nigeria. Journal of Mining and Geology Vol. 48(1): pp. 13-29.

[84] O'e Connor, J. T. (1965). A classification for quartz-rich igneous rocks based on feldspar ratios. US Geological Survey, Professional Papers 52(5): pp. 79-84.

[85] Odeyemi, I. B (1977): The basement rocks of Bendel state of Nigeria. Unpublished Ph. D. Thesis. University of Ibadan.

[86] Okunlola, O. A. (2001): Geological and Compositional Investigation of Precambrian Marble Bodies and associated Rocks in the Burum and Jakura areas, Nigeria. Ph.d Thesis, University of Ibadan, Nigeria, 193p.

[87] Okunlola and Okoroafor, (2009).I: Geochemical and petrogenetic features of schistose rocks of the Okemesi fold belt, Southwestern Nigeria RMZ - Materials and Geoenvironment, Vol. 56, No. 2, pp. 148-162, 148

[88] Okonkwo, C. T. and Winchester, J. A. 1996. Geochemistry and geotectonic setting of Precambrian amphibolites and granitic gneisses in the Jebba area, Southwestern Nigeria. J. Min. Geol. 32(1), pp. 1-18

[89] Okonkwo, C. T. and Winchester, J. A., 2004. Geochemistry of granitic rocks in Jebba area, southwestern Nigeria. Journal of Mining and Geology, Vol. 40(2), pp. 95 - 100. https://doi.org/10.4314/jmg.v40i2.18814.

[90] Olade, M. A. and Elueze, A. A. 1979. Petrology and geochemistry of the Ilesha amphibolites and Precambrian crustal evolution in the Pan-African domain of south-western Nigeria. Precam. Res. 8, pp. 303-318. https://doi.org/10.1016/0301-9268(79)90033-0.

[91] Olobaniyi, S. O. (2003) Geochemistry of semi politic schist of Isanlu area, Southwestern Nigeria: Implication for the geodynamic evolution of the Egbe-Isanlu Schist belt. Global Journal of Geological Sciences; Vol. 1, No. 2, pp. 113-127. https://doi.org/10.4314/gjgs.v1i2.18661.

[92] Ogezi, A.E.O. (1977): Geochemistry and geochronology of basement rocks north-western Nigeria. Unpublished Ph.D. Thesis, Leeds University United Kingdom pp. 200-207

[93] Oluyede, O. K., Garba, I., Danbatta, U., Ogunleye, P. and Klötzli, U. (2021a). Field occurrence, petrography and structural characteristics of basement rocks of the northern part of Kushaka and Birnin Gwari schist belts, northwestern Nigeria. Journal of Natural Sciences Research. Vol. 12 No. 12 ISSN (Paper) 2224-3186 (Online) 2225-0921 https://doi.org/10.7176/JNSR.

[94] Oluyede, O. K., Garba, I., Danbatta, U., Ogunleye, P. and Klötzli, U. (2021b). Geochemistry and petrogenesis of banded and granitic gneisses of the northern part of Kushaka schist belts northwestern Nigeria. Journal of Environmental and Earth Science. ISSN (Paper) 2224-3216 (Online) 2225-0948 https://doi.org/10.7176/JEES.

[95] Olarewaju, V. O. and Rahaman, M. A., 1982. Petrology and Geochemistry of Older Granites from some parts of Northern Nigeria. Journal of Mining and Geology, 18(2), pp. 16-28.

[96] Pearce, J. A. and Cann, J. R. (1973). Tectonic setting of basic volcanic rocks determined using trace element analyses. Earth and Planetary Science Letters. 19, 290-300 https://doi.org/10.1016/0012-821X(73)90129-5.

[97] Pearce, J. A. and Norry, M. J. (1979). Petrogenetic implications of Ti, Zr, Y and Nb variations in volcanic rocks. Contributions to Mineralogy and Petrology 69, 33-47 https://doi.org/10.1007/BF00375192.

[98] Pearce, J. A. Harris, N. B. W. and Tindle, A. G. W. 1984. Trace Element Discrimination Diagrams for the Tectonic İnterpretation of Granitic Rocks. Journal of Petrology, 25, (4), 956-983. https://doi.org/10.1093/petrology/25.4.956.

[99] Pearce, J. A. Bender, J. F. De Long, S. E. Kidd, W. S. F. Low, P. J. Güner, Y. Şaroğlu, F. (1990). Genesis of Collision Volcanism in Eastern Anatolia, Turkey. Journal of Volcanology and Geothermal Research. Vol. 44, No. 1-2, pp. 189-229. https://doi.org/10.1016/0377-0273(90)90018B.

[100] Pitcher, W. S. (1983). Granite type and tectonic environment. In K. Hsu (Ed.), Mountain Building Processes (pp. 19-40). London: Academic Press.

[101] Peccerillo, A., and Taylor, S. R. (1976): Geochemistry of Eocene calc-alkaline volcanic rocks from the Kastamonu area, northern Turkey. Contributions to Mineralogy and Petrology, 58: pp. 63-81. https://doi.org/10.1007/BF00384745.

[102] Prinz, M. (1967). Geochemistry of basaltic rocks: trace elements. In: Hess HH Poldervaart A. (Eds.) Basalts 2 Interscience New York, 271 325.

[103] Rahaman, M. A. 1976. Review of the basement geology of southwestern Nigeria. In: Geology of Nigeria. (Edited by C. A. Kogbe). Elizabethan Publishing Company Lagos, 41-58

[104] Rahaman, M. A. 1988. Recent advances in the study of the basement complex of Nigeria. In: Precambrian Geology of Nigeria. (Eds. Oluyide et al.) a publication of the Geol. Surv. Nigeria. 71-43.

[105] Rahaman, M. A., Emofurieta, W. O. and Caen-Vachette, M., 1983. The potassic of Igbeti area: Further evidence of the polycyclic evolution of the Pan-African belt southwestern Nigeria. Precambrian Research, 22, pp. 75 -92. https://doi.org/10.1016/0301-9268(83)90059-1.

[106] Roberts, M. P. and Clemens J. D. 1993. The origin of high-potassium calc-alkaline I-type granitoids. Geology 21, 825-828. https://doi.org/10.1130/0091-7613(1993)021<0825:OOHPTA>2.3.CO;2.

[107] Roddaz M, Viers J, Brusset S, Baby P, Boucayrand C, Hérail G. (2006). Controls on weathering and provenance in the Amazonian foreland basin: Insights from major and trace element geochemistry of Neogene Amazonian sediments. Chemical Geology. 226 (1) $31-65$. https://doi.org/10.1016/j.chemgeo.2005.08.010.

[108] Rollinson, H. R., 1993. Using Geochemical Data: Evaluation, Presentation and Interpretation. Longman Group, Uk Ltd. Co-published in the United States with John Wiley and Sons, New York, 352.

[109] Rottura, A., Bargossi, G. M., Caggianeli, A., Del Moro, A., Visona, D. and Tranne, C. A. 1998. Origin and significance of the Permian high-K calc-alkaline magmatism in the central-eastern Southern Alps, Italy. Lithos 45, (1-4) 329-348. https://doi.org/10.1016/S0024-4937(98)00038-3.

[110] Schluter, T., 2005. Geological Atlas of Africa: With Notes on Stratigraphy, Tectonics, Economic Geology, Geohazards, Geosites and Geoscientific Education of Each Country. 2nd Edition. Springer, 272p. 
[111] Soesoo, A. 2000. Fractional Crystallization ofmantle-derived melts as a mechanism for some I-type granite petrogenesis: an example from Lachlan Fold Belt, Australia. Journal of Geological Society, London 157, 135-149. https://doi.org/10.1144/jgs.157.1.135.

[112] Streckeisen, A., (1976). To each plutonic rock its proper name. Earth Science Review 6: 181-217.

[113] Sun, L. M. and Chen, J. C. (1992) Geochemical study of granites from Chimen (Quemoy) and Hong Kong, Southeastern China. Journal of Southeast Asian Earth Sciences 7, (4), 237-245. https://doi.org/10.1016/0743-9547(92)90003-T

[114] Sun S. S. and McDonough, W. F. (1989). Chemical and isotopic systematics of oceanic basalts: implications for mantle composition and processes. In: Saunders A.D., Norry M.J. (Eds.). Magmatism in the ocean basins. Geological Society of London, Special Publication, 42:313-345. https://doi.org/10.1144/GSL.SP.1989.042.01.19.

[115] Tarney J. \& Jones C.E. 1994. Trace element geochemistry of orogenic igneous rocks and crustal growth models. Journal of the Geological Society, 151(5):855-868. https://doi.org/10.1144/gsigs.151.5.0855.

[116] Truswell, J. F. and Cope, R. N. 1963. The geology of parts of Niger and Zaria Provinces, Northern Nigeria. Bulletin Geological Survey Nigerian 29, 38.

[117] Tubosun, I. A., Lancelot, J. R., Rahaman, M. A., Ocan, O., 1984. U-Pb Pan-African ages of two charnockite-granite association from southwestern Nigeria. Contribution to Mineralogy and Petrology 88, 188-195. https://doi.org/10.1007/BF00371422.

[118] Turner, D. C. 1983: Upper Proterozoic schist belts in the Nigerian sector of the Pan African Province of West Africa. Precambrian Research 21, 5-79. https://doi.org/10.1016/0301-9268(83)90005-0.

[119] Ukwang, E., and Ekwueme, B. N. (2009): Geochemistry and geotectonic study of granitic rocks of southwest Obudu Plateau, southeastern Nigeria. Journal of Mining and Geology, 45: pp. 73-82.

[120] Van Breemen, O., Pidgeon, R. T. and Bowden, P. 1977. Age and isotopic studies of some Pan-African granite from North-central Nigeria Precambrian Research 4, 319-407. https://doi.org/10.1016/0301-9268(77)90001-8

[121] Whalen J. B., Currie K. L. and Chappell B. W. 1987. A-type granites: Geochemical characteristics, discrimination and petrogenesis Contributions Mineralogy Petrology 95: 407-419. https://doi.org/10.1007/BF00402202.

[122] White, A. J. R., (2001) Water, Restite and Granite Mineralization. Australian Journal of Earth Sciences, 48, 551-555. https://doi.org/10.1046/j.1440-0952.2001.00878.x.

[123] Woakes. M. Rahaman, M. A. \& Ajibade. A. C. 1987. Some metallogenic features of the Nigerian basement. Journal of African Earth Sciences, 6, 655-664. https://doi.org/10.1016/0899-5362(87)90004-2.

[124] Wright, J. B., 1985. Fracture systems in Nigeria and initiation of fracture zones in the South Atlantic. Tectonophysics, 34, 43-47. https://doi.org/10.1016/0040-1951(76)90093-7.

[125] Zorano S. S; Martin H., Jean-jacques P; Emanuel F. J. and Maria H. F. M. (2007): Calc-Alkaline Magmatism at the Archean-Proterozoic Transition: the Caico Basement Complex (NE Brazil) Journal of Petrology 48 (11): pp. 2149-2185. https://doi.org/10.1093/petrology/egm055. 